\title{
DINÂMICA DE PLANTAS INVASORAS EM SISTEMAS AGROFLORESTAIS IMPLANTADOS EM PASTAGENS DEGRADADAS NA AMAZÔNIA CENTRAL (região de Manaus-AM)
}

SILAS GARCIA AQUINO DE SOUSA

Engenheiro Agrônomo

Orientador: Prof. Dr. Virgílio Maurício Viana

Dissertação apresentada à Escola Superior de Agricultura "Luiz de Queiroz", da Universidade de São Paulo, para obtenção de título de Mestre em Ciências, Área de Concentração: Ciências Florestais.

P I R A C I C A B A

Estado de São Paulo - Brasil

Fevereiro - 1995 
Ficha catalografica preparada pela Seça de Livros da Divisào de Biblioteca e Documentaçäo - FCLQ/USF

\footnotetext{
Sousa, Silas Garcia Aquino de

5729d Dinamica de plantas invasoras em sistemas agroflo restais implantados em pastagens degradadas na Amazó ria Central (regiao de Manaus-AM). Firacicata, 1995. 57P.

Diss. (Mestre) - ESALG

Bibliugrafia.
}

1. Desmatamento - Amazania Central 2. Fastagem - De gradaça - Fecuperaçào $\Xi$. Sistema agroflorestal - Flan ta daninira - Dinamica I. Escola Superior de AgricultLi ra Luiz de Gueiroz, Firacicaba 


\section{DINAMICA DE PLANTAS INVASORAS EM SISTEMAS AGROFLORESTAIS IMPLANTADOS EM PASTAGENS DEGRADADAS NA AMAZÔNIA CENTRAL (região de Manaus-AM)}

SILAS GARCIA AQUINO DE SOUSA

Aprovada em: 29/03/1995

Comissão julgadora:

Prof. Dr. Virgilio M.Viana

Prof. Dr. Robson A. Pitelli

Prof. Dr. Érick C. M. Fernandes

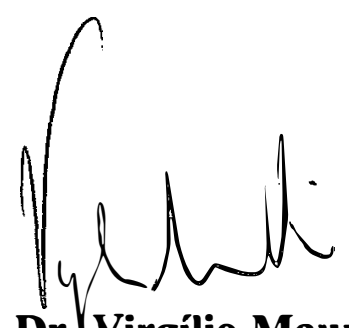

Prof. Dr.|Virgílio Maurício Viana orientador 
Aos meus pais, Manoel Aquino

(in memorium) e Ivanice Garcia

de Sousa,

Minha gratidão.

A minha esposa, Lucinda, pela compreensão, abnegação e apoio nos momentos mais dificeis,

Ofereço.

Aos meus filhos Paloma e Rafael pelo carinho e paciência pelas hora e horas de espera, Dedico. 


\section{AGRADECIMENTOS}

À Empresa Brasileira de Pesquisa Agropecuária -EMBRAPA, pela oportunidade de realização deste curso;

Ao Convênio EMBRAPANCSU (Universidade Estadual da Carolina do Norte)/RF (Fundação Rockfeler) pelo apóio logístico e financeiro para realização deste trabalho;

Ao Prof. Dr. Virgílio Mauricio Viana, pela compreensão, incentivo e orientação;

Ao Prof. Dr. Erick C. M. Fernandes pelo apoio, confiança e valorosas sugestões;

Ao Prof. Dr. Robson A. Pitelli, pelas primeiras sugestões e estimulo que culminaram com a realização deste trabalho;

Ao Prof. Dr. Antonio Natal Gonçalves pela compreensão, amizade e colaboração;

Aos Professores dos Departamentos de Ciências Florestais, Horticultura e Agricultura, pelos ensinamentos e convivênvia durante o decorrer do curso;

Ao Pesquisador da EMBRAPA Manoel da S. Cravo pelas criticas, sugestões e revisões do texto e, a sua família pelo carinho e amizade dispensada a mim e a minha família;

Ao Colega Viseldo R. de Oliveira pela amizade e constantes trocas de idéias;

Aos colegas do Curso, principalmente àqueles que participaram de algum modo com a reaiização deste trabalho (Domingos, Gláucia, Erika, Edson e Deoclides) 
Ao Marcelo (Siri) e Milton C. Ribeiro (Miltinho), pelo auxílio nas análises dos dados;

À bibliotecária Kátia M. de A. Ferraz, pela revisão das referências bibliográficas;

Aos irmãos Suely e Carlos Rubens da Costa pela amizade, hospedagem e condução durante a finalização deste trabalho;

Aos funcionários dos herbários do INPA e do Dep. de Botânica da ESALQ/USP pela colaboração na identificação das plantas;

Ao funcionários do Laboratório de análises de solos e planta pelas analises químicas de solos e tecido foliar;

Ao pesquisador da EMBRAPA, João Carlos de S. Matos, pela amizade e incentivo na realização deste curso;

À Aurora Malcher e Marilza Siqueira, do SRH/CPAA/EMBRAPA, pelo apoio dispensado a mim e minha familia;

Aos trabalhadores de campo sem o qual parte deste trabalho não existiria;

Aos Técnicos Agrícolas Luciana, Robenildo e James que auxiliaram na coleta dos dados;

Aos Colegas do convênio, EMBRAPA/NCSU, Marcelo Arcoverde, Thomas Ludewigs, Acácia Neves e Rogério Perin pelo apoio e convívio no decorrer da execução dos experimentos e,

À todos àqueles que, me apoiaram no decorrer deste curso e direta ou indiretamente colaboraram para a realização deste trabalho. 


\section{SUMÁRIO}

Página

LISTA DE FIGURAS ….......................................................... ix

LISTA DE TABELAS ..................................................................

LISTA DE APÊNDICES ................................................................ xiii

RESUMO

SUMMARY

1. INTRODUÇÃO ....................................................................... 1

1.1. O problema das pastagens na Amazônia e suas consequências e perspectivas ........................................................................ 1

1.2. Conceito de plantas invasoras .................................................... 4

1.3. Importância das plantas invasoras nos agroecossistemas .............. 5

1.4. Métodos de controle de plantas invasoras em sistemas

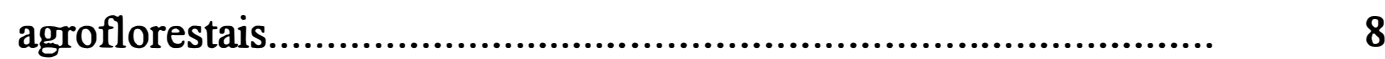

1.5. Dinâmica da comunidade de plantas invasoras ............................... 12

1.6. Problema de pesquisa .................................................................. 16

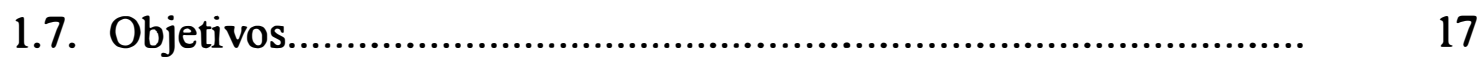

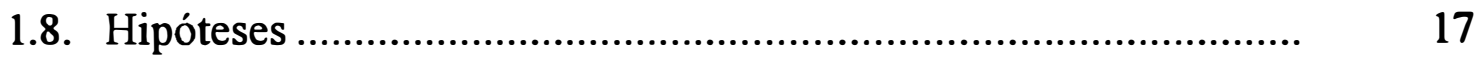

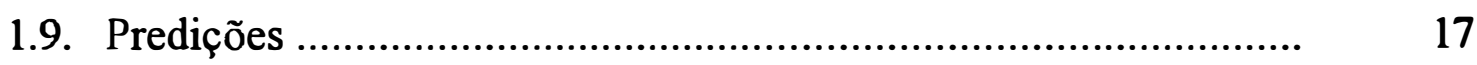

2. MATERIAL MÉTODOS ….......................................................... 18

2.1. Características da Área.............................................................. 18

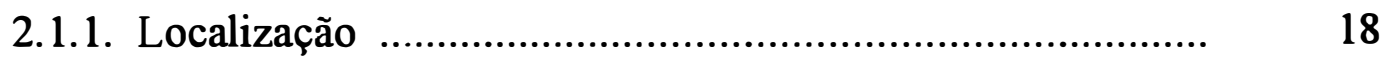

2.1.2. Clima ...................................................................... 18

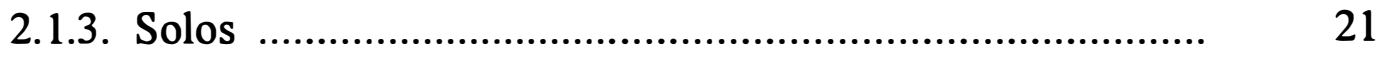

2.1.4. Vegetação .................................................................. 22

2.2. Descrição das pastagens e dos sistemas agroflorestais .................. 23 
2.2.1. Histórico das pastagens …............................................... 23

2.2.2. Delineamento estatístico dos Sistemas Agroflorestais-SAFs. $\quad 24$

2.2.3. Composição dos sistemas agroflorestais ............................. 25

2.3. Obtenção dos dados ................................................................ 29

2.3.1. Descrição, demarcação e área de amostragens no campo ... 29

2.3.2. Coleta dos dados .......................................................... 31

2.3.2.1 Determinação do tipo de regeneração...................... 31

2.3.2.2 Determinação do estágio de desenvolvimento ........ 32

2.3.2.3 Avaliação da fitomassa e análise foliar de macro

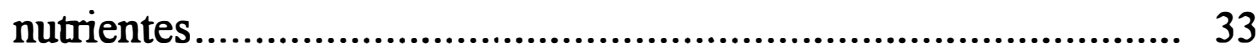

2.3.3. Identificação das espécies...............................................

2.4. Análise dos dados ............................................................. 34

2.4.1. Determinação dos parâmetros fitossociológicos.................. 35

3. RESULTADOS E DISCUSSÃO .......................................................... 39

3.1. Caracterização da Comunidade de Plantas Invasoras nos Sistemas. 39

3.1.1. Composição, estrutura e regeneração da comunidade de

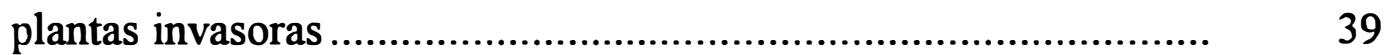

3.1.1.1 Composição florística da comunidade ................... 39

3.1.1.2 Estrutura da comunidade.................................... 42

3.1.1.3 Regeneração e estágio de crescimento.................... 48

3.1.1.3.1 Regeneração ......................................... 48

3.1.1.3.2 Estágios de crescimento ......................... 51

3.2. Variação da comunidade de plantas invasoras em 4 sistemas agroflorestais........................................................................ 53

3.2.1. Efeito dos sistemas agroflorestais na composição florística 53

3.2.1.1 Distribuição das Famílias, Gêneros e Espécies...... 53

3.2.1.2 Índice de Diversidade Shannon Weaver ................ 54 
3.2.1.3 Índice de Similaridade de Jaccard - ISJ ................. 56

3.2.2. Efeito dos sistemas agroflorestais na densidade ................. $\quad 57$

3.2.3. Efeito dos sistemas agroflorestais na frequência ................. 61

3.2.4. Efeito dos sistemas agroflorestais na fitomassa................... 64

3.2.5. Dinânica das espécies mais comuns nos sistemas

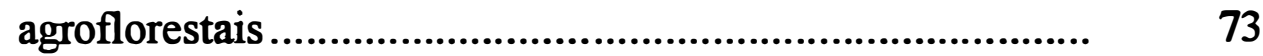

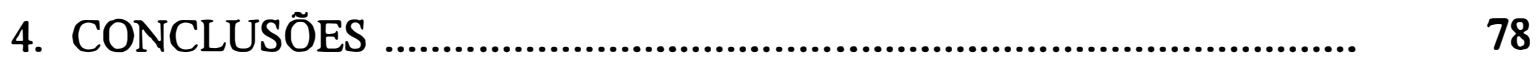

4.1 Perspectiva para o manejo de plantas invasoras em sistemas agroflorestais na Amazônia ....................................................... $\quad 79$

REFERÊNCIAS BIBLIOGRÁFICAS …............................................. 85

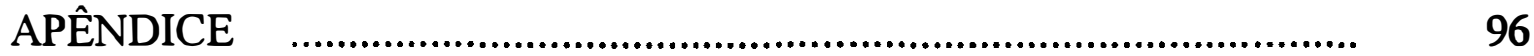




\section{LISTA DE FIGURAS}

FIGURAS

Página

1. Localização da Estação Experimental da EMBRAPA/CPAA, na

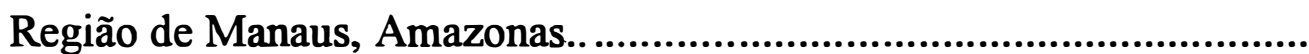

2. Croqui com detalhe dos blocos e parcelas dos sistemas agroflorestais.

3. Detalhe da parcela do Sistema Agrossilvicultural 1 -SAF1. 26

4. Detalhe da parcela do Sistema Agrossilvicultural 2 - SAF2 ................

5. Detalhe da parcela do Sistema Agrossilvipastoril 1 e 2-SAF3 e SAF4. 28

6. Detalhe da parcela de coleta dos dados 30

7. Número acumulado de espécies (monocotiledôneas e dicotiledôneas) ocorrentes nos sistemas agroflorestais, durante 18 meses de coleta......

8. Porcentagem de nutrientes acumulados na fitomassa das mono e dicotiledôneas ocorrentes nos sistemas agroflorestais.

9. Frequência (\%) da ocorrência de plantas invasoras originadas de sementes e rebrotamento ao longo de 18 meses.

10. Distribuição dos indivíduos (\%) e, 3 estágios de desenvolvimento (plântulas, jovens e adultas).

11. Densidade (ind. $/ \mathrm{m}^{2}$ ) de mono e dicotiledôneas ocorrentes nas parcelas dos sistemas agroflorestais (SAF1, SAF2, SAF3 e SAF4). As médias seguidas da mesma letra não diferem entre si, ao nível de $5 \%$ de probabilidade pelo teste Tuckey...

12. Densidade relativa (\%) das espécies nos SAF1, SAF2, SAF3 e SAF4.

13. Frequência relativa (\%) das 10 espécies mais comuns nos SAF1, SAF2, SAF3 e SAF4. 
14. Fitomassa das plantas invasoras nas parcelas, SAF1 = sistema agrossilvicultural1; SAF2 = sistema agrossilvicultural2 - multiestrato; SAF3 = sistema agrossilvipastoril - baixos insumos e SAF4 = sistema agrossilvipastoril - altos insumos. Médias seguidas da mesma letra não diferem significativamente entre si, ao nível de $5 \%$ de probabilidade pelo teste de Tuckey................................................

15. Fitomassa relativa (\%) das 10 principais espécies nos SAFs................ 68

16. Fitomassa das invasoras em $\left(\mathrm{g} / \mathrm{m}^{2}\right)$, dentro e nas faixas entre linhas dos componentes arbóreos do SAF3, ao longo de 18 meses... .............

17. Fitomassa das invasoras em $\left(\mathrm{g} / \mathrm{m}^{2}\right)$, dentro e nas faixas entre linhas dos componentes arbóreos do SAF4, ao longo de 18 meses... .............

18. Dinâmica da fitomassa $\left(\mathrm{g} / \mathrm{m}^{2}\right)$ das 5 espécies mais comuns $\mathrm{Br}($ Borreria verticillata), $\mathrm{Bh}$ (Brachiaria humidicola), $\mathrm{Fa}$ (Fimbristylis annua), Pc (Paspalum conjugatum) e Sj (Solanum

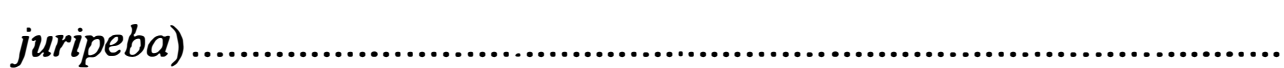




\section{LISTA DE TABELAS}

TABELA

Página

1. Dados mensais de precipitação pluviométrica $(\mathrm{mm})$ e médias mensais de temperatura máximas e minimas $\left({ }^{\circ} \mathrm{C}\right)$ de mar/93 a set/94, registrados pela estação metereológica instalada no local do ensaio (EEDA/EMBRAPA, km 54 da BR 174).

2. Análise granulométrica do Latossolo Amarelo argiloso do $\mathrm{km} 52 \mathrm{da}$ BR 174 realizado em $1971 .$.

3. Análise química do solo (Latossolo Amarelo muito argiloso) no $\mathrm{km} 54$ da BR 174, antes da queima (nov/91), durante a implantação dos sistemas agroflorestais.

4. Lista das espécies, com as respectivas famílias, nome vulgar e hábito de crescimento

5. Parâmetros fitossociológico; densidade absoluta - DA $\left(\mathrm{m}^{2}\right)$, densidade relativa - DR (\%), frequência absoluta - FA, frequência relativa - FR (\%), fitomassa absoluta - FTA $\left(\mathrm{g} / \mathrm{m}^{2}\right)$, fitomassa relativa (\%), indice de McGinnies - IMc (padrão de distribuição das espécies) e índice de valor de importância - I.V.I.

6. Densidade (NR.IND.-número de indivíduos $/ \mathrm{m}^{2}$ ) e fitomassa (peso em $\mathrm{g} / \mathrm{m}^{2}$ ) total das mono e dicotiledôneas ocorrente nos sistemas durante as 5 coletas.

7. Tipo de regeneração das mono e dicotiledôneas por $\mathrm{m}^{2}$ por período de coleta $(1,2,3,4,5)$.

8. Regeneração das mono e dicotiledôneas por $\mathrm{m}^{2}$ por parcela (SAF1, SAF2, SAF3, SAF4). 
9. Número de famílias, gêneros, espécies, suas restrições nos quatro sistemas (SAF1, SAF2, SAF3 e SAF4) e porcentagem, em relação ao total..

10. Índice de diversidade de Shannon Weaver $\left(\mathrm{H}^{\prime}\right)$ e equabilidade $(\mathrm{J})$ para as comunidades de plantas invasoras, ao longo de 18 meses em Sistemas Agroflorestais, em pastagens degradadas...........................

11. Índice de Similaridade de Jaccard (\%)............................................ 55

12. Concentração de nutrientes $(\%)$ e conteúdo $(\mathrm{kg} / \mathrm{ha})$ por $\mathrm{SAF}$ das 5 principais espécies 


\section{LISTA DE APÊNDICES}

TABELAS

Página

1. Lista da presença das espécies nos sistemas e pastagens........................ 97

2. Lista de presença das espécies nos períodos. ...................................... 99

3. Índice de valor de importância das espécies no SAF1 por período........ 101

4. Índice de valor de importância das espécies no SAF2 por período........ 102

5. Índice de valor de importância das espécies no SAF3 por período........ 103

6. Índice de valor de importância das espécies no SAF4 por período. ....... 104

FIGURAS

Página

1. Dados mensais de precipitação pluviométrica $(\mathrm{mm})$ e médias mensais de temperatura $\left({ }^{\circ} \mathrm{C}\right)$ de mar/93 a set/94 e normais de 1981 a 1992, registrados pela estação metereológica instalada no local do ensaio (EEDA, km 54 da $\mathrm{Br} 174$ ) 


\title{
DINÂMICA DE PLANTAS INVASORAS EM SISTEMAS AGROFLORESTAIS IMPLANTADOS EM PASTAGENS DEGRADADAS NA AMAZÔNIA CENTRAL (região de Manaus - AM)
}

\author{
Autor: SILAS GARCIA AQUINO DE SOUSA \\ Orientador: Prof. Dr. VIRGÍlLIO MAURÍCIO VIANA
}

\section{RESUMO}

Foi avaliada a dinâmica de plantas invasoras que ocorrem no estrato inferior de 4 Sistemas Agroflorestais, implantados em áreas de pastagens degradadas e abandonadas localizadas no km 54 da BR 174 da estrada ManausBoa Vista, no que diz respeito à sua densidade, diversidade, frequência e acúmulo de fitomassa.

Os dados foram obtidos em 5 coletas em um período de 18 meses, através de amostragens, em quadrados de $0,25 \mathrm{~m}^{2}$ distribuídos, aleatoriamente, em parcelas de $300 \mathrm{~m}^{2}$, totalizando 180 amostras por sistema $\left(900 \mathrm{~m}^{2}\right)$.

Foram identificadas 63 espécies, abrangendo 40 gêneros e 18 famílias botânicas. As famílias Poaceae (17 espécies), Asteraceae (7 espécies), Cyperaceae ( 7 espécies), Solanaceae ( 5 espécies) e Euphorbiaceae (5 espécies) contribuiram com o maior número de espécies, enquanto as demais apresentaram 1 a 4 espécies.

As monocotiledôneas, compreendendo 3 espécies, foram dominantes em densidade, frequência e fitomassa, enquanto as dicotiledôneas apresentaram maior diversidade, indivíduos relativamente mais pesados $\mathrm{e}$ apresentaram maiores porcentagens de nutrientes $(\mathrm{N}, \mathrm{P}, \mathrm{K}, \mathrm{Ca}$ e $\mathrm{Mg})$. 
As famílias Poaceae, Cyperaceae, Solanaceae, Rubiaceae e Verbenaceae, representadas por 10 espécies de maior Índice de Valor de Importância, formaram a base das comunidades de invasoras que ocorrem nos sistemas. Dentre essas 10 espécies destacaram-se: Solanum juripeba Rich., Fimbristylis annua Roem Sch., Brachiaria humidicola (Rend.) Sch., Paspalum multicaule Poir, Borreria verticillata (L.) G.F.W. Meyer e Paspalum conjugatum Berg., com valores acima da média para fitomassa ou densidade ou frequência.

Os SAFs não influenciaram na densidade (número de indivíduos $/ \mathrm{m}^{2}$ ) das plantas invasoras, mesmo assim, registrou-se um número maior de plantas $/ \mathrm{m}^{2}$ no SAF2. O SAF4 apresentou, 2 espécies restritas ao sistema (Physalis pubescens L.e Commelina benghalensis L.).

A fitomassa no SAF2 foi superior a dos SAFs 3 e 4 e as espécies que mais contribuiram para o aumento da fitomassa foram: Solanum juripeba Rich., Brachiaria humidicola e Paspalum conjugatum. No SAF4, devido ao manejo do solo (calagem, adubação e gradagem) a fitomassa de Solanum juripeba foi reduzida.

Verificou-se, que o arranjo espacial dos SAF3 e SAF4 com linhas tríplas de cultivos arbóreos e faixas entre as linhas, ocupadas com culturas anuais, favoreceram a menor densidade, frequência e fitomassa de plantas invasoras. indicando a importância dos arranjos, na definição e implantação dos sistemas agroflorestais.

A avaliação da dinâmica de plantas invasoras esclareceu, parcialmente, o comportamento dessas plantas no estrato inferior dos sistemas, gerando informações preliminares que poderão subsidiar as tomadas de decisões para o manejo mais adequado das plantas invasoras nos sistemas agroflorestais a serem implantados, em áreas semelhantes ao do estudo. 


\section{WEED POPULATION DYNAMICS IN AGROFORESTRY \\ SYSTEMS STABLISHED ON DEGRADED PASTURES IN THE \\ CENTRAL AMAZON BASIN (Manaus region - AM)}

Author: SILAS GARCIA AQUINO DE SOUSA Advisor: Prof. Dr. VIRGILIO MAURICIO VIANA

SUMMARY

The dynamics of weedy species that occur at the low strata of 4 Agroforestry Systems (SAF's), established on degraded and/or abandoned areas located at km 54 of BR 174 at Manaus - Boa Vista road, was evaluated for its density, diversity, frequency and above-ground biomass stoge.

The data were obtained from five field observations in a period of 18 months, using square plots of $0.25 \mathrm{~m}^{2}$, randomly distributed, with a total of 180 plots per system $\left(900 \mathrm{~m}^{2}\right)$.

The floristic survey found 63 species, 40 genera and 18 botanic families. Poaceae (17 species), Asteraceae (7 species), Cyperaceae (7 species), Solanaceae (5 species) and Euphorbiaceae (5 species) contributed with the larger number of species, while the other families had 1 to 4 species.

Monocotyledonous species represented by 3 families of grasses, were dominant in density, frequency and above-ground biomass, while dicotyledonous species (forbs and shrubs) showed the highest values of diversity, individual dry weight and \% of nutrients $(\mathrm{N}, \mathrm{P}, \mathrm{K}, \mathrm{Ca}$ and $\mathrm{Mg})$.

The families Poaceae, Cyperaceae, Solanaceae, Rubiaceae and Verbenaceae, represented by the first 10 species had higher importance 
values. Between these species 6 showed results above the average for aboveground biomass, density and frequency: Solanum juripeba Rich., Fimbristyiis annua Roem. Sch., Brachiaria humidicola (Rend.) Sch., Paspalum multicaule Poir., Borreria verticullata (L.) G.F. W. Meyer and Paspalum conjugatum Berg.

Weed density (number of individuals/ha) was significanty not influenced by structure on the different agroforestry systems. SAF4 had 2 restricted species to that system (Physalis pubescens L. and Commelina benghalensis L.).

The above-ground biomass on SAF2 was higher than SAF' 3 and SAF4 and the species which had highest above-ground biomass were: Solanum juripeba Rich., Brachiaria humidicola and Paspalum conjugatum. SAF 4, due soil management practices (lime, fertilization requirement and incorporated with a moldboard plow) had lowest biomass for Solanum juripeba.

The utilization of triple lines with planted trees followed by opened strips with annual crops for SAF3 and SAF4, collaborated for a lower weed occurrence on density, frequency and fitomass, suggesting the importance of these specific arrangement on the definition and establishment of agroforestry systems.

The evaluation of weed population dynamics explained, in part. the plant behavior under the low strata at the systems, generating preliminary informations that could aid with the best weed management decision-making for the agroforestry systems, that could be established under conditions similar to that of the study site. 


\title{
1. INTRODUÇÃO
}

\subsection{O problema das pastagens na Amazônia, suas conseqüências e perspectivas.}

\begin{abstract}
A substituição da Floresta Amazônica por pastagens cultivadas constitui uma das alterações ambientais mais importantes e problemáticas da região, visto que, foram estabelecidas sob sistemas de pastagens monoculturais, introduzidas de outras regiões, ocupando grandes áreas em solos de baixa fertilidade, para uma atividade extensiva, com baixa capacidade de sustentação e competição com as plantas invasoras de pastagens. Para DANTAS (1980), o agroecossistema de pastagens cultivadas caracteriza-se por ser simplificado, floristicamente pobre, altamente instável e incapaz de se autosustentar, além de exportar grandes variáveis de nutriente, sob forma de forragem ou de carne. Com o passar do tempo, a manutenção deste sistema torna-se insustentável ecologicamente e inviável economicamente. Deste modo, as pastagens cultivadas na Amazônia, progressivamente vão sendo invadidas pelas "Juquiras" (denominação na Amazônia para plantas invasoras em pastagens), chegando ao ponto de completo desaparecimento do capim cultivado.
\end{abstract}

O problema da degradação e conseqüente abandono das áreas de pastagens na Amazônia tem sido atribuído a falta de manejo adequado e a elevada lotação de animais por hectare. A renovação e adubação das pastagens periodicamente, principalmente adubação com fósforo, o controle efetivo das plantas invasoras e a rotação dos animais entre os pastos (piquetes), são algumas das recomendações preconizadas por diversos autores na região(SERRÃO et al 1979; DIAS FILHO \& SERRÃO 1987). Entretanto, devido aos altos custos dos insumos para recuperação da fertilidade dos solos e escassez de mão de obra para o controle das plantas invasoras, tais recomendações nem sempre são adotadas pelos pecuaristas que preferem continuar derrubando a floresta para formaçăo de 
novas pastagens à investirem na recuperação das áreas já desmatadas (FEARNSIDE 1980).

$\mathrm{Na}$ Amazônia, além dos desmatamentos provocado pelos médios e grandes fazendeiros para formação de pastagens, amplia-se o problema da agricultura itinerante (agricultura baseada no corte e queima da floresta com dois subsistemas consecutivos: a fase de cultivo com plantas úteis e a fase de pousio com vegetação secundária) devido, principalmente a elevada pressão populacional, que foi reduzindo cada vez mais a fase de pousio e a floresta secundária (capoeira) foi perdendo a sua capacidade e função de reservar nutrientes para a fase seguinte e também de frear à expansão das plantas invasoras que se instalam durante a fase de cultivo (DENICH 1991). A observância da fase de pousio por um período mais longo com capoeiras produtivas, é imprescindível para evitar a degradação dos ecossistemas da agricultura itinerante, já que a produtividade do sistema é decisivamente determinada pelas árvores que gozam de vantagens sobre a concorrência.

Enquanto se discutem soluções para o problema das pastagens e da agricultura migratória, os desmatamentos e queimadas na Amazônia continuam, e as áreas degradadas e abandonadas aumentam. Atualmente, estimam-se que existam cerca de $200 \mathrm{mil} \mathrm{km}{ }^{2}$ de pastagens em diferentes estágios de degradação e abandono na Amazônia (FERNANDES et. al., 1994a). Portanto, a recuperação das áreas degradadas na Amazônia e a busca de alternativas para as pastagens e melhoria dos sistemas agrícolas tradicionais (agricultura itinerante) compatíveis com as características locais de cada microrregião, aliadas às necessidade do manejo florestal sustentado desafiam a comunidade científica no sentido de encontrar sistemas de produção que contemplem as condições ecológicas e sócio-econômicas regionais.

Uma das alternativas indicadas para Amazônia são os Sistemas Agroflorestais (SAFs), que poderão diminuir a pressão dos desmatamentos sobre a floresta para abertura de novas áreas, oferecendo alternativas para melhorar a "capoeira"(vegetação secundária) de baixa produtividade que emerge após o abandono da área no sistema de cultivo 
itinerante e também para recuperar as áreas de pastagens degradadas e abandonadas na Região.

Os sistemas agroflorestais envolvem um conjunto de combinações possíveis de culturas agrícolas (anuais à perenes), com espécies florestais e produção animal de forma simultânea ou seqüêncial, visando a utilização dos recursos disponíveis à integração e o desenvolvimento sócioeconômico da região com o meio ambiente. Tais sistemas são citados por diversos autores, como opção de manejo e uso dos solos nos Trópicos, entre eles: NAIR (1993), SERRÃO \& HOMMA (1991); VIANA \& SIQUEIRA (1992), REDFORD et al. (1992) e FERNANDES (1994a).

Devido às extensas áreas degradadas e/ou abandonadas ou com problema de baixa produtividade na Amazônia, diferentes sistemas vêem sendo testados por diversas instituições de pesquisas da Região. Entre estes sistemas, são mencionados o processo de regeneração natural (UHL et al. 1990), o aproveitamento da vegetação secundária para incremento da matéria orgânica nos sistemas de produção (DENICH 1991) e, a recuperação dessas áreas através da implantação de diferentes sistemas agroflorestais (FERNANDES et al., 1994b).

Em Manaus - AM, o Centro de Pesquisa Agroflorestal da Amazônia Ocidental. da Empresa Brasileira de Pesquisa Agropecuária CPAA/EMBRAPA, está empenhado em avaliar diferentes sistemas agroflorestais para recuperação das pastagens degradadas e abandonadas na Amazônia Ocidental. Neste sentido, FERNANDES et al. (1994b), testaram diferentes sistemas em pastagens degradadas e abandonadas com a finalidade de comparar a produtividade, economicidade e a dinâmica de nutrientes no solo nessas áreas. Nesse trabalho, os autores depararam-se com os problemas enfretados pelos agroecossistemas convencionais e tradicionais implantados na Amazônia, principalmente à baixa fertilidade dos solos das pastagens degradadas e a pressão das plantas invasoras nas áreas cultivadas.

O presente trabalho discute o problema das plantas invasoras que ocorrem no estrato inferior dos Sistemas Agroflorestais (SAFs) implantados 
para recuperação de pastagens degradadas na Amazônia central, no que diz respeito a sua densidade, diversidade e fitomassa acumulada, com vistas ao seu controle, a custo mais reduzidos.

\subsection{Conceitos de plantas invasoras}

Plantas invasoras recebem diferentes conceituações entre os autores e diversos nomes que variam entre regiões e países. Entretanto, de um modo geral, há uma concordância no sentido de que, são plantas que podem gerar algum tipo de prejuízo ao homem, podendo tornar-se uma praga nas áreas cultivadas, até o momento que se descobre nelas algum valor econômico e passam à categoria de plantas úteis (ALBUQUERQUE 1978).

Com referência à nomenclatura destas plantas, existe uma lista enorme de nomes, sendo os mais conhecidos: plantas daninhas, plantas invasoras, plantas infestantes, plantas nativas, plantas silvestres, plantas nocivas, plantas ruderais, plantas secundárias, ervas daninhas, ervas invasoras, mato, erva má, inço e juquira.

Os conceitos de plantas invasoras são baseados na indesejabilidade e normalmente são denominadas de "plantas daninhas". Shaw (1956), citado por ALBUQUERQUE (1978), conceituou: 'Daninha é uma planta que ocorre onde não é desejada". LORENZI (1994), ampliou este conceito e definiu: "Planta daninha é qualquer ser vegetal que cresce onde não é desejado". Dentro dessa definição ampla incluiu também a tigüera de cultura (plantas remanescente da cultura anterior) que vegetam espontaneamente em lavouras subsequentes àquelas. LEITÃO FILHO et al.(1972), consideram planta invasora quaisquer plantas, sejam elas cultivadas ou silvestre, que vegetam em locais onde a sua presença não é desejada. Apesar de utilizarem a nomeclatura "blanta invasora", o conceito da indesejabilidade permanece e, KISSMANN \& GROTH (1992) as considera, como "plantas infestantes e nocivas", que prejudicam direta ou indiretamente a vida do homem e as atividades agrícolas, classificando-as de nocivas no mesmo grau de importância das pragas e doenças que ocorrem nos agroecossistemas. 
Indesejáveis ou nocivas, as plantas invasoras ocorrem espontaneamente em áreas relacionadas com as atividades humanas, em algum momento e, de alguma forma interferem vegetativamente em suas atividades. Portanto, a vegetação secundária (plantas invasoras) que ocorre nos agroecossistemas é uma conseqüência das alterações (nichos) ecológicas criados pelo homem (BLANCO 1972). Tais alterações, aliadas à eficiência dos órgãos de propagação, plasticidade e variabilidade genética, permitem que essas plantas sobrevivam sob condições estressantes dos ecossistemas agricolas e migrar para outros sistemas, garantindo a sobrevivência e a expansão geográfica de suas populações.

No presente estudo, foi adotado o termo 'planta invasora", no sentido de que um conjunto de espécies vegetais nativas ou imigrantes estariam ocupando espontaneamente determinadas áreas cultivadas pelo homem, onde haveria disponibilidade de recursos de produção para o desenvolvimento de seu ciclo de vida, contudo nem todas estas espécies secundárias nos sistemas são indesejáveis, algumas poderão em determinadas condições, tornarem-se componentes principais, como, plantas forrageiras, medicinais ou produtoras de nectar e/ou pólen garantindo a produção de mel o ano todo e a presença de polinizadores na áreà.

\subsection{Importância das plantas invasoras nos agroecossistemas}

Nos sistemas agrícolas e florestais, a ocorrência de plantas invasoras vem predominantemente causando prejuizos na produção, tanto pela competição direta com fatores de produção, quanto pela interferência sobre as plantas cultivadas, como ocorre no caso da alelopatia. No Brasil as plantas invasoras são responsáveis pela quebra na produção do arroz de sequeiro na ordem de 56 a 70\% DOMINGES et al. (1982). Para a cultura do milho, causa uma redução de 25 a 30\%, na produção (LORENZI 1980). Enquanto que em florestas implantadas, as plantas invasoras são responsáveis por uma redução no volume cúbico de madeira em torno de 68 a $72 \%$ para Eucalyptus grandis Hill ex Maiden ZEN (1987). Nos sistemas consorciados, não se pode esperar grandes 
produções quando o sistema está submetido às condições de pressão da cobertura de plantas invasoras (ALTIERI \& LIEBMAN 1986). A obtenção de produções econômicas dependem da escolha das espécies e cultivares (componentes herbáceos, arbustivos e arbóreos), densidade do plantio e manejo das invasoras.

Para os pecuaristas as plantas invasoras constituem-se um dos maiores problemas, principalmente nos sistemas monoculturais extensivos ou semi-intensivos de produção. Na Amazônia os custos com o manejo das plantas invasoras carecem de maiores informações, porém na região de Paragominas estimam-se que o controle de invasoras demandam de 10 a $20 \%$ dos gastos da fazenda (Hecht 1979 citado por DANTAS \& RODRIGUES 1980) e esses percentuais aumentam com a degradação das pastagens e a presença de plantas tóxicas que resulta em doenças e morte dos animais. É importante reconhecer que a presença das plantas invasoras no atual modelo de produção provocam prejuízos e reduções significativas na produtividade das plantas cultivadas. Por outro lado convém lembrar que as plantas invasoras são decorrentes das alterações ecológicas criadas pelo homem, portanto, em sistemas manejados adequadamente a vegetação invasora é mínima e com menores custos de produção( PRIMAVESI, 1992).

A maior parte das citações bibliográficas destacam principalmente os prejuízos causados pelas plantas invasoras na agricultura moderna, especialmente devido a competição por luz, água, nutrientes e espaço com as culturas econômicas. Porém, cerca de 20 espécies de plantas são invasoras problemáticas em todo o mundo (ZINDAHL 1981). Muitas destas foram introduzidas com as culturas, outras são nativas que ocorrem após perturbações promovidas pelo homem. Poucas citações relatam os beneficios que as plantas invasoras poderão oferecer aos agroecossistema: como por exemplo a cobertura do solo impedindo a erosão e a lixiviação de nutrientes; como adubo verde, reciclando nutrientes para o sistema; como plantas companheiras, dificultando o ataque de pragas e doenças ou mantendo o equilíbrio térmico do solo e; como apícolas e plantas medicinais. 
Entre aquelas plantas consideradas invasoras por diversos autores, existem muitas leguminosas que são procuradas pelo gado, como aquelas pertencentes aos gêneros Desmodium, Stylosanthes, Centrosema, Arachis, Camptosema, Galactia, Macroptilium (BRANDÃO et al.1985). Outras principalmente do gênero: Crotalaria, Canavalia e Indigofera são relacionadas para adubação verde (FORNARI 1983, KOEPF et al., 1984, entre outros).

Entre outros fatores a manutenção das plantas invasoras nos sistemas agroflorestais poderão proporcionar as funções de produção de fitomassa e acumulação de nutrientes. Cujos produtos da decomposição parcial dos resíduos orgânicos (galhos, folhas e raizes) resultante das capinas, juntamente com a biomassa microbiana dos solos representam os componentes mais ativos da matéria orgânica e dos nutrientes reciclados no sistema solo/planta (POWLSON et al., 1987; DENICH, 1991 e LUIZÃO \& LUIZÃO, 1991).

As plantas invasoras, são potencialmente espécies fornecedoras de néctar e pólen, pois, apresentam vantagens sobre as plantas cultivadas usuais de matéria-prima para o mel-de-abelha devido as suas rusticidades e capacidades de sobreviverem em diferentes sistemas (BRANDÃO et al., 1984). Na medicina popular a maioria das plantas consideradas como invasoras são classificadas como medicinais, entre elas Borreria verticillata (L.) G.F.W. Meyer. é vomitiva e suas raizes contém o mesmo alcalóide (emetina) da ipecacuanha (LORENZI 1986), Solanum jurepeba Rich., (jurubebinha), tem uso na medicina popular regional para febres da malária e afeções hepáticas.

Algumas plantas consideradas como invasoras (que apresentam caracteristicas de espécies pioneiras) são muito importantes para o manejo de áreas degradadas, pois possuem grande potencial de colonização e rápido crescimento, o que facilita a viabilidade econômica das iniciativas de recuperação, ao mesmo tempo, tais espécies podem facilitar o estabeleciento de outras espécies caractrísticas de estágios sucessionais mais avançado (VIANA, 1987).

Tais exemplos demonstram que as plantas consideradas como invasoras podem ser componentes dos agroecosssistemas e devem ser manejadas 
no sentido da convivência com as plantas cultivadas. Evidências recentes sugerem que a presença de invasoras nos campos cultivados não pode ser, automaticamente, julgadas como prejudiciais. As relações entre a densidade de plantas invasoras e produção agrícola podem ser senoidais, ao invés de lineares. Em densidades baixas, as invasoras geralmente não afetam a produção e, sob algumas circunstâncias, certas ervas até estimulam o crescimento da cultura, como por exemplo, em áreas não irrigadas da zona árida da Índia, ervas como Arnebia hispidissima, Borreria articularis e Celosia argentea aumentaram o crescimento e a produção de "bajra" (Pennisetum typhoideum) mas não do gergelim (Sesamum indicum), enquanto que a presença de Indigofera cordiflora foi benéfica para ambas as espécies (ALTIERI, 1989). Foi observado também um aumento do peso seco do trigo com aumento da densidade da leguminosa Tripollo polycersta (Kapoor \& Ramakrishnan, 1975 citado por ALTIERI, 1989).

Portanto, generalizações sobre os danos causados pelas invasoras podem ser inapropriadas, visto que, muitas espécies podem apresentar características desejáveis para determinados sistemas de produção. Entretanto, quando há desequilíbrio na densidade e diversidade de plantas invasoras com as plantas cultivadas no sistema, justifica-se a adoção de medidas de controle ou a retirada de apenas as espécies realmente indesejáveis.

\subsection{Métodos de controle de plantas invasoras em sistemas agroflorestais}

Os componentes vegetais dos sistemas agroflorestais, para desenvolverem-se harmonicamente de forma eficaz e sustentáveis, necessitam de suprimentos adequados de água, nutrientes, luz, e espaço. Em função disso, são impiantados em diferentes espaçamentos e densidades, de tal maneira que tenham condições de minimizar a competição e otimizar a produção no sistema. Porém, as plantas invasoras ocorrem aleatoriamente e espontaneamente no tempo e no espaço, comprometendo o equilibrio entre os fatores de produção do meio e a produtividade dos componentes cultivados nos sistemas. Em decorrência destes problemas, torna-se necessário o manejo de plantas invasoras em sistemas 
agroflorestais, principalmente na fase inicial quando necessita-se obter produções de alimentos para o pequeno produtor e produções econômicas para amortizar os custos de implantação dos sistemas agroflorestais na média e grande propriedade.

Nos agroecossistemas convencionais os métodos de controle de plantas invasoras sãc os mais variados possíveis. Entre eles, os mais usados são: controle manual, capinas (manuais e mecanizadas); controle químico e controle preventivo. Além destes, outros também são citados como, o controle cultural e controle biológico (KLINGMAN \& ASHTON, 1975; VICTORIA FILHO, 1988; LORENZI, 1986), entre outros.

O controle biológico das plantas invasoras vem sendo abordado como uma das alternativas de manejo mais seguro e mais econômico em relação aos herbicidas e capinas. É um método que vem sendo utilizado nos Estados Unidos e outro países para invasoras de difícil controle por outros meios, e uma das vantagens dos bioherbicidas é que podem ser produzidos em pequena escala e a baixo custo, podendo ser usados para plantas invasoras de culturas de menor importância e onde a área envolvida, não justifica o desenvolvimento de herbicidas específicos (YORINORI, 1987). Entretanto para usar o controle biológico de plantas invasoras, é necessário conhecer a flora infestante, selecionar as espécies de plantas que irão ser controladas, selecionar os inimigos naturais mais eficientes, determinar a especificidade dos hospedeiros e até mesmo introduzir nos sistemas biocontroladores exóticos, desde que se tenha a garantia de como estes agentes irão se comportar no novo ambiente (RODRIGUES, 1985). Portanto, consideramos que o contrcle biológico das plantas invasoras deverá ser o manejo do futuro, atualmente pouco se sabe a respeito dos possíveis agentes, os custos, benefícios e conseqüências para os sistemas agroflorestais na Amazônia.

Em sistemas agroflorestais o manejo das plantas invasoras vem sendo discutido através da habilidade das plantas cultivadas em competirem com as invasoras, da densidade e arranjo dos componentes arbóreos e não arbóreos nos sistemas, do efeito do sombreamento através do crescimento rápido das espécies cultivadas sobre as invasoras, do efeito do "mulching" sobre a germinação do banco de sementes, da alelopatia prevenindo a germinação das 
sementes e inibindo o crescimento das invasoras e também, através da remoção das invasoras pelo pastejo de bovinos, ovinos e caprinos (PLUCKNETT \& SMITH, 1986; OLADOKUN, 1989 e CARVALHO \& TORRES, 1994). Todos estes processos podem reduzir a densidade e biomassa das populações de plantas invasoras, em diferentes tipos de sistemas agroflorestais,

Durante a implantação dos sistemas agroflorestais, os cultivos temporários (arroz, milho, feijão amendoim, batata doce, mandioca, etc.) necessitam de maiores cuidados e devem permanecer livres das plantas invasoras pelo menos nas 5 primeiras semanas após a semeadura. Superado este período, a densidade (maior número de plantas por área), combinação de plantio (consórcio ou rotação) e variedades bem adaptadas exercem importante papel no controle das invasoras através do sombreamento e a cobertura permanente do solo.

A cultura do milho, milheto e feijão (caupi), inibem muito mais a ocorrência de invasoras do que a cultura do arroz, amendoim e mandioca, entretanto arroz e amendoim mais adensados poderão ter o mesmo efeito do milho e do feijão. Por outro lado, quando plantados juntos (consorcio) a ocorrência das plantas invasoras deverá variar de acordo com a proporção dos componentes (AKOBUNDU, 1980; (BANTILAN et al., 1974; SHETHY \& RAO, 1981 e YIH, 1982) citado por PLUCKNETT \& SMITH, 1986). Outra observação importante nos consórcios são aquelas em que as espécies intercaladas com a cultura principal possuem o efeito de 1 a 3 capinas manuais. A Batata doce, melão, abóbora, caupi ou amendoim quando intercalados com milho, sorgo ou mandioca podem substituir as capinas geralmente usada nestas culturas (AKOBUNDU, 1980; PLUCKNETT \& SMITH, 1986 e OLADOKUN, 1989).

A cobertura morta no solo provoca reduções significativas na occrrência das plantas invasoras nos agroecossistemas através dos efeitos físicos, químicos e biológicos. O bloqueio na penetração de luz e a manunetação do equilíbrio térmico no solo são efeitos físicos que dificultam a germinação das sementes que necessitam de variações térmicas e presença de luz. Àquelas que conseguem germinar podem sofrer ação das substâncias alelopáticas da cobertura morta, reduzindo o seu crescimento e desenvolvimento e provocando sua morte 
na fase inicial. Quando a cobertura morta entra em processo de decomposição, aumenta as atividades biológicas no sistema, a predação e inviabilidade do banco de sementes do solo, reduzindo as emergências das plantas invasoras nas áreas cultivadas. Os restos culturais de milho ou arroz deixados na área como cobertura morta, são mais eficientes na redução do crescimento de invasoras da cultura subsequente (feijão, mandioca, entre outras) do que os restos culturais de feijão, mandioca ou amendoim, que decompõem-se mais rapidamente (SANCHEZ, 1976; SCHONINGH et al.,1986; PALM, 1988; OLADOKUN, 1989; SANCHEZ \& BENÍTES, 1991; DEUBER, 1991 e CARVALHO \& TORRES, 1994). A cobertura morta associada às outras formas de controle, deverão funcionar efetivamente como método alternativo de manejo das plantas invasoras em sistemas agroflorestais.

O plantio de leguminosa nas entrelinhas dos consórcios arbóreos, na entre safra ou na fase de pousio é um outro tipo de cobertura do solo que pode funcionar como método de manejo das plantas invasoras nos sistemas agroflorestais inibindo a germinação do banco de sementes das invasoras no solo. As espécies mais usadas nestes casos seriam: mucuna preta e anã, guandu, tremoço, ervilhaca, calopogônio, puerária e caupi (PRIMAVESI, 1992 e DEUBER, 1992). Portanto a cobertura morta e verde destacam-se como métodos potencialmente viáveis e indicados para serem utilizados em sistemas agroflorestais.

Em determinados sistemas como, os agrosilvipastoris o uso combinado de ovinos, caprinos e bovinos podem ser manejados para o controle das plantas invasoras com sucesso e, na fase adulta dos sistemas agrosilviculturais (consórcios de espécies frutíferas com espécies florestais) o fechamento das copas das árvores exercem efetivamente o controle das plantas invasoras (OLADOKUN, 1989 e CARVALHO \& TORES, 1994), reduzindo drasticamente a biomassa dessas espécies nos sistemas agroflorestais.

Todos estes métodos não podem ser usados isoladamente, pois o meio mais eficaz para se combater as plantas invasoras é o uso combinado de diferentes práticas e métodos, visando aproveitar bem os recursos disponíveis, 
com maior eficiência, reduzindo custos e obtendo a otimização da produção em beneficio do homem. A combinação destes métodos, associando-os ao combate de pragas, doenças e o controle da erosão é denominado de manejo integrado ou controle integrado (DEUBER, 1992). O objetivo central do manejo integrado das invasoras, é a manipulação da relação planta cultivada versus invasora de maneira que o crescimento das plantas cultivadas seja favorecido e as plantas invasoras, poderão permanecer no sistema $\mathrm{em}$ níveis ecológico, agronômico e economicamente aceitáveis (ALTIERI, 1988). Entretanto, para que se tenha sucesso na integração dos métodos de manejos, é necessário o conhecimento da dinâmica de população das plantas invasoras nos sistemas.

\subsection{Dinâmica da comunidade de plantas invasoras}

A dinâmica de populações, é o estudo das variações no número de indivíduos da população e dos fatores que influenciam essas variações. Igualmente, inclui a investigação das taxas de natalidade e mortalidade dos indivíduos e de qualquer processo regulador que possa afetar o tamanho da população. Dinâmica de populações é a expressão de um sistema em atividade (SALOMON, 1980 e ODUM, 1988). Os organismos não se adaptam simplesmente de forma passiva neste sistemas, podem modificar e regular ativamente o ambiente físico dentro dos limites impostos pelas leis naturais que determinam a transformação da energia e a ciclagem de mateiras

A população pode ${ }^{98}$ definida como qualquer grupo de organismo da mesma espécie que ocupa um determinado espaço e funciona como uma parte da comunidade biótica, geralmente com capacidade de trocar genes entre si. Comunidade, por sua vez, é definida como um conjunto de populações que funcionam como uma unidade integradora através de transformações metabólicas co-evoluídas numa determinada área ou habitat fisico (ODUM, 1988).

As comunidades de plantas invasoras caracterizam-se por uma notável resistência e plasticidade às condições adversas de clima, solo e perturbações. São de crescimento relativamente rápido, produzem grandes 
quantidades de sementes e propágulos, facilmente dispersáveis e germinação descontínua no tempo e espaço (BLANCO, 1985). Tais características, permitemnas sobreviver em condições estressantes e migrar para outros sistemas, causando transtornos ao homem. Um espécime (ecótipo) colonizador pode emergir de restos de ramos ou partes de plantas da comunidade anterior, do banco de sementes ou de propágulos migrantes (KELLMAN, 1980). Também poderia chegar através dos implementos agrícolas e mudas contaminadas com propágulos de plantas invasoras provocando a substituição da comunidade predominante ou alterando a composição florística em densidade e diversidade de uma área cultivada ou não.

Estudos da dinâmica de populações de plantas invasoras, no que diz respeito à composição florística, densidade, diversidade e distribuição em ambientes constantemente perturbados pelo homem (agroecossistemas), indicam que as alterações que as comunidades sofrem, quando submetidas constantemente em ambiente estressante (aração, gradagem, adubação, correção do solo, herbicidas e outros manejos culturais), provocam desequilíbrio nas populações, com aparecimento e desaparecimento de espécies, ou alterando o valor de importância de outras, que se modificam de acordo com as práticas culturais e intensificação dos cultivos (ROBERTS, 1963; CHANCELLOR, 1985; DERKSEN et al., 1993). Portanto, devido o processo continuo de eliminação e controle das comunidades de plantas invasoras nos agroecossitemas, raramente as espécies atingem a capacidade de suporte de densidade populacional, sugerindo que as comunidades de plantas invasoras existem sob condições de populações com regulação independente de densidade (KELLMAN, 1980). A composição florista de plantas invasoras também pode variar nas diferentes estações do ano e condições climáticas (ALMEIDA \& RODRIGUES, 1985).

Nos Trópicos, as comunidades de plantas invasoras dominantes nos agroecossistemas são formadas pelas espécies nativas e as cosmopolitas. O tipo de solo e as práticas agrícolas são fatores mais importante do que o tipo de cultura na determinação da composição e tamanho das comunidades de plantas invasoras de cada sitio e, a distribuição dos indivíduos de diferentes espécies nas áreas cultivadas tende a ser heterogênea, em resposta aos aspectos da biologia reprodutiva e dispersão das sementes (KELLMAN, 1980). Porém, além 
do conhecimento da população vegetativamente ativa no sistema é necessário estudar a dinâmica dessas populações no estado latente, isto é, no banco de sementes do solo.

O banco de sementes, refere-se a sementes, frutos. propágulos e outras estruturas vegetativas reprodutivas encontrada no solo, como parte de uma comunidade de espécies vegetal (WILLIAMS, 1984). O banco de sementes do solo pode ser visto como um sistema dinâmico, com entradas, através da dispersão e chuva de semente e, saídas, que pode ocorrer por predação, doenças, envelhecimento e germinação da semente (KAGEYAMA \& VIANA, 1989). Portanto a densidade e diversidade do banco de sementes do solo variam no tempo e no espaço e dependem das estratégias de vida de cada espécie e das condições ambientais.

Esta potencial forma de vida das populações de plantas invasoras já eram conhecidas, desde 1918 em Londres, por Brenchley, citado por FREITAS (1990), que juntamente com Warington foram os pioneiros na tentativa de avaliar as sementes enterradas no solo. (Brenchley \& Warington, 1930, 1933, e 1936) citados por GARCIA (1988), iniciaram seus trabalhos a partir de amostras de solo coletadas anualmente em áreas cultivadas com trigo e colocadas para germinar em vasos em casa de vegetação, passaram a observar a magnitude da densidade e riqueza de espécies de plantas presente nas amostras coletadas. Porém, somente a partir da década de 80 os bancos de sementes têm merecido atenção por parte dos pesquisadores, interessados em conhecer a dinâmica das populações a fim de intervirem, quando necessário, para manter sob controle as espécies indesejáveis.

A evolução dos estudos da dinâmica de população, biologia, banco de sementes, taxas de germinação e mortalidade destas espécies, constituem, atualmente, uma ferramenta capaz de prever a ocorrência e o tamanho da futura comunidade de plantas que poderão infestar uma determinada área. Entretanto, a emergência de determinadas espécies não depende somente do estoque de sementes no solo mas, também, das condições ambientais adequadas, para a germinação e desenvolvimento da planta (HARPER, 1977),. Portanto, o 
número de indivíduos presente no banco de sementes (propágulos e sementes dormentes), é muito maior do que o número de plantas na fase vegetativa na maioria dos habitats avaliados e, por outro lado, nem sempre as espécies presente no banco de semente fazem parte da composição florística num determinado momento. A densidade da flora local representa apenas 2 a $10 \%$ da encontrada no banco de sementes (ROBERTS, 1981).

As flutuações estacionais da densidade e diversidade da composição florística do banco de sementes têm sido pouco estudadas. Porém alguns autores relatam que, geralmente, os estoques de sementes refletem o tipo de perturbação no ambiente, bem como os aspectos fenológicos das espécies na área ou próximo dela. As arações consecutivas, com a manutenção de monocultivos, alteraram a diversidade e densidade da comunidade infestante, reduzindo as monocotiledôneas e favorecendo as dicotiledôneas (FROUDWILLIAMS et al., 1983). Nas pastagens o banco de semente é mais estável e apresenta uma dominância por monocotiledôneas. Enquanto que na rotação de culturas, prevalece um menor número de sementes de ambos os grupos.

No plantio direto as sementes no solo devem estar em condições diferentes daquelas encontradas no plantio convencional, estariam em condições estáveis quanto ao microclima e baixos níveis de perturbações, o que impede a emergència de muitas espécies. Por outro lado as espécies com capacidade de regeneração vegetativa são as mais problemáticas no plantio direto. No sul do Brasil, foi observado que o cultivo convencional (com aração) proporcionou maior infestação de invasoras do que o plantio direto e, a ocorrência de uma deteminada espécie numa estação estava relacionada com a fenologia desta espécie (ALMEIDA \& RODRIGUES, 1985). É importante observar que o plantic direto no sul do Brasil foi implantado em áreas tradicionalmente cultivadas com plantio convencional, portanto um dos maiores problemas no início no plantio direto são as invasoras, porém a medida que o estoque de semente no solo vai se esgotando e os restos vegetativos das culturas (palhada) vão se acumulando as sementes migrante não chegam ao solo e a maioria das que chegam são impedidas de germinarem, devido a camada de proteção do solo, reduzindo a densidade e biomassa das invasoras no plantio direto. 
Considerando o impacto que as plantas invasoras representam sobre a produtividade dos agroecossistemas, estudos da dinâmica da população das espécies invasoras deverão ser intensificados a fim de que os técnicos possam fazer as previsões e orientar as tomadas de decisões em relação ao manejo dessas plantas nos sistemas cultivados.

\subsection{Problema de pesquisa}

Um dos principais problemas da baixa produtividade dos agroecossistemas na Amazônia, deve-se ao aumento e interferência das plantas invasoras nos agroecossistemas convencionais, que, aliados aos altos custos para o controle das plantas invasoras, obrigam o produtor sem alternativa a abandonar sua área de produção e provocar novos desmatamentos na floresta.

Uma das alternativas indicadas para Amazônia são os sistemas agroflorestais (SAFs), que podem diminuir a pressão dos desmatamentos sobre a floresta para abertura de novas áreas, melhorar a vegetação secundária (capoeira) de baixa produtividade que emerge após o abandono da área no sistema de cultivo itinerante, recuperar as áreas degradadas ou abandonadas e melhorar a qualidade de vida das populações da região. Além disso, nos SAFs, a medida que as árvores crescem o problema com as invasoras diminuem. Entretanto no inicio da implantação dos sistemas agroflorestais a interferência das plantas invasoras, constituem-se um dos fatores mais limitaste para o seu estabelecimento. Por esta razão, o presente trabalho, analisa a dinâmica da vegetação secundária (plantas invasoras) que ocorre no estrato inferior de 4 sistemas agroflorestais (SAFs), implantados para recuperação de pastagens degradadas na Amazônia central, no que diz respeito a sua densidade, diversidade e fitomassa acumulada, com vista ao seu controle a custo mais reduzidos. 


\subsection{Objetivos}

1.7.1. Caracterizar a comunidade de plantas invasoras que ocorrem nos sistemas agroflorestais, quanto à sua composição florística, estrutura e regeneração.

1.7.2. Avaliar o efeito dos diferentes tipos de sistemas agroflorestais na comunidade de plantas invasoras, quanto à sua densidade, diversidade e fitomassa acumulada por estas plantas.

\subsection{Hipótese}

A vegetação secundária (plantas invasoras) que está ocorrendo no estrato inferior dos sistemas agroflorestais implantados para recuperação de pastagens degradadas na Amazônia ocidental nos sistemas agroflorestais, deve variar de acordo com os diferentes tipos de sistemas (SAFs) implantados.

\subsection{Predições}

1.9.1. Espera-se que a densidade, diversidade e fitomassa da comunidade de plantas invasoras sejam influenciadas pelos diferentes tipos de sistemas agroflorestais e de acordo com histórico de manejo de cada sistema.

1.9.2. Espera-se que a intensificação do preparo do solo (gradagem, calagem e adubação), deva exercer influência negativa sobre a emergência de plantas, contribuindo para uma menor densidade e diversidade populacional de espécies invasoras que ocorrem durante fase inicial de implantação dos sistemas agroflorestais.

1.9.3. Espera-se um aumento do número de espécies invasoras e uma diminuição do número de indivíduos das espécies predominantes ao longo do tempo nos diferentes tipos de sistemas agroflorestais. 


\section{MATERIAL E MÉTODOS}

\subsection{Caracterização da Área}

\subsubsection{Localização}

O estudo foi realizado em Sistemas Agroflorestais implantados para recuperar uma área de pastagem abandonada, no ex-Campo Experimental de Zootecnia da UEPAE/EMBRAPA-Manaus, atual Estação Experimental do Distrito Agropecuário da Suframa da CPAA/EMBRAPAManaus (Centro de Pesquisa Agroflorestal da Amazônia Ocidental da Empresa Brasileira de Pésquisa Agropecuária), localizada na Amazônia Ocidental brasileira ao norte de Manaus, no km 54 da BR 174 (Figura 1), entre as coordenadas geográficas $2^{\circ} 31^{\prime}$ a $2^{\circ} 32^{\prime}$ de latitude sul e $60^{\circ} 01^{\prime} 60^{\circ} 02^{\prime}$ de longitude WGr.

\subsubsection{Clima}

Pela classificação de Köppen, a região integra o quadro macroclimático do tipo Ami, caracterizado pelas estações de clima quente úmido, temperatura constantemente e precipitação pluviométrica anual em tomo de 3.000 $\mathrm{mm}$. Verificou-se durante o período do presente estudo (mar/93 a set/94) um regime de chuvas variando de 104 a $401 \mathrm{~mm}$, temperatura média do periodo foi de $25,6^{\circ} \mathrm{C}$, com mínimas de $20,7^{\circ} \mathrm{C}$ e máximas $33,9^{\circ} \mathrm{C}$ (Tabela 1). A Umidade Relativa do $\mathrm{Ar}$, foi de 80 a $93 \%$, com média anual de $86 \%$, caracterizando a microregião como tropical úmida bastante chuvosa, sem período seco definido. 


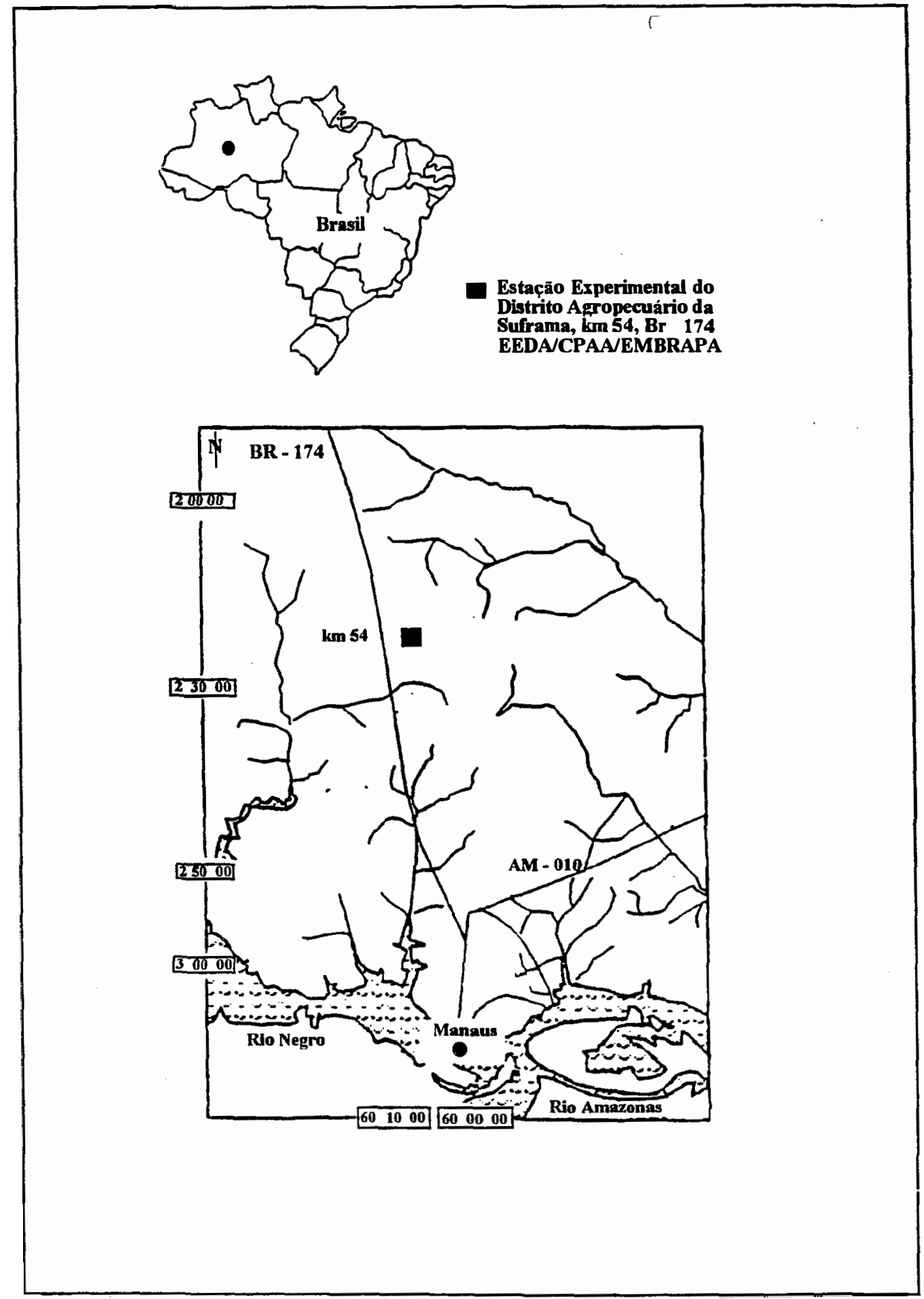

Figura 1- Localização da Estação Experimental da EMBRAPA/CPAA, na Região de Manaus, Amazonas. 
As médias climatológicas observadas neste periodo (mar/93 a set/94) diferem dos dados normais (1981 a 1992) refletindo a passagem do fenômeno El Niño na região (Figura 1 - apêndice)

Tabela 1 - Dados mensais de precipitação pluviométrica ( $\mathrm{mm}$ ) e médias mensais de temperatura máxima, mínima e média $\left({ }^{\circ} \mathrm{C}\right)$ de mar/93 a set/94, registrados pela estação metereologica instalada no local do ensaio (EEDA, Km 54 da Br 174).

\begin{tabular}{|c|c|c|c|c|c|c|c|c|}
\hline \multirow[t]{3}{*}{ Meses } & \multicolumn{2}{|c|}{$\begin{array}{l}\text { Precipitação pluviométrica } \\
\text { (mm) }\end{array}$} & \multicolumn{6}{|c|}{ Temperatura do $\operatorname{ar}^{\circ} \mathrm{C}$} \\
\hline & & & \multicolumn{2}{|c|}{ Máxima } & \multicolumn{2}{|c|}{ Minima } & \multicolumn{2}{|c|}{ Média } \\
\hline & \multicolumn{2}{|r|}{1994} & 1993 & 1994 & 1993 & 1994 & 1993 & 1994 \\
\hline JAN & - & 159.5 & - & 30.6 & - & 23.1 & - & 25.8 \\
\hline FEV & - & 275.4 & - & 30.0 & - & 22.1 & - & 24.8 \\
\hline MAR & 172.4 & 300.5 & 31.3 & 30.7 & 23.9 & 22.2 & 26.7 & 25.2 \\
\hline ABR & 298.7 & 401.6 & 30.2 & 31.1 & 23.0 & 22.2 & 25.6 & 25.4 \\
\hline MAI & 170.9 & 262.3 & 31.3 & 31.5 & 22.5 & 22.3 & 25.8 & 25.5 \\
\hline JUN & 191.3 & 210.6 & 31.6 & 30.7 & 21.8 & 21.5 & 25.6 & 24.9 \\
\hline JUL & 156.5 & 104.4 & 31.1 & 31.4 & 20.9 & 20.9 & 24.8 & 24.9 \\
\hline AGO & 123.5 & 165.9 & 32.1 & 32.6 & 20.7 & 21.1 & 25.1 & 25.5 \\
\hline SET & 139.2 & 123.2 & 32.8 & 33.9 & 21.4 & 22.1 & 25.9 & 26.7 \\
\hline OUT & 140.6 & - & 32.1 & - & 21.9 & - & 25.7 & - \\
\hline NOV & 112.0 & - & 31.6 & - & 22.3 & - & 25.8 & - \\
\hline DEZ & 111.3 & - & 32.1 & - & 23.0 & - & 26.6 & - \\
\hline MED & $1616.3^{*}$ & $1843.8^{*}$ & 31.6 & 31.4 & 22.1 & 21.9 & 25.8 & 25.4 \\
\hline
\end{tabular}

$\left({ }^{*}\right)$ precipitação total no período. 


\subsubsection{Solos}

Os solos da área de estudo foram classificados pelo (IPEAAOc, 1971), como Latossolo Amarelo muito argiloso (Tabela 2), denominados de solos de terra firme de formação recente, originados de sedimentos argilosos do Terciário, reperesentados pela Série Barreiras. O relevo da região é suavemente ondulado, com platôs argilosos e baixios arenosos.

Tabela 2 - Análise granulométrica do Latossolo Amarelo argiloso do km 52 da BR174 realizado em 1971.

\begin{tabular}{c|cccccc}
\hline HORIZONTES & $\begin{array}{c}\text { PROFUNDIDAD } \\
\text { E (cm) }\end{array}$ & $\begin{array}{c}\text { AREIA GROSSA } \\
(\%)\end{array}$ & AREIA FINA (\%) & $\begin{array}{c}\text { SILTE (\%) } \\
\text { ARGILA TOTAL } \\
(\%)\end{array}$ & $\begin{array}{c}\text { ARGILA } \\
\text { NATURAL (\%) }\end{array}$ \\
\hline A 1 & $0-7$ & 8 & 1 & 0 & 91 & 43 \\
A 2 & $7-27$ & 1 & 1 & 2 & 91 & 34 \\
B 1 & $27-66$ & 4 & 1 & 3 & 92 & 0 \\
B 2 & $66-102$ & 4 & 1 & 2 & 93 & 0 \\
\hline
\end{tabular}

Fonte : IPEAAOc (1971)

Devido às características do material de origem, lixiviação e histórico de uso, o solo caracteriza-se por apresentar baixos teores de nutrientes disponíveis para as plantas e alta saturação de alumínio, conforme análise química do solo (Tabela 3) realizada durante a instalação dos experimentos, em novembro de 1991, após cerca de 8 anos de pastejo e 5 anos de abandono da área de pastagens. 
Tabela 3 - Análise química do solo (Latossolo Amarelo muito argiloso) no km 54 da BR 174, antes da queima (nov/91), durante a implantação dos sistemas agroflorestais.

\begin{tabular}{|c|c|c|c|c|c|c|c|c|c|c|}
\hline $\begin{array}{l}\text { PROF. } \\
(\mathrm{cm})\end{array}$ & $\overline{\mathrm{pH}}$ & SAT. BASE & $\mathrm{C}$ & $\mathrm{N}$ & $\mathbf{P}($ Ext. $)$ & $\begin{array}{l}\text { P(TOTAL) } \\
\text { m }\end{array}$ & $\mathrm{Ca}$ & $\begin{array}{l}\mathrm{Mg} \\
\mathrm{cmc}\end{array}$ & & CTC \\
\hline $00-15$ & 4.3 & 50.4 & 2.6 & 0.20 & 2.5 & 100 & 0.89 & 0.32 & 0.09 & 2.52 \\
\hline $15-30$ & 4.3 & 41.8 & 1.6 & 0.13 & 1.2 & 81 & 0.55 & 0.21 & 0.05 & 1.94 \\
\hline $30-45$ & 4.3 & 34.2 & 1.1 & 0.09 & 1.0 & 70 & 0.37 & 0.14 & 0.03 & 1.59 \\
\hline
\end{tabular}

Fonte: McKERROW (1992)

\subsubsection{Vegetação}

A vegetação da Região pode ser classificada como floresta densa de terra firme de alta diversidade, com cerca de 500 a 700 árvores e 100 a 280 espécies de árvores em cada hectare e possui uma biomassa de 406 ton/ha (KLINGE, 1976 e GENTRY, 1988).

A vegetação atual, sob forma de vegetação secundária, ou capoeira de pastagens degradada e/ou adandonada é formada por 39 espécies, representada por 34 gêneros de 24 famílias botânicas, de acordo com levantamento florístico realizado na área de estudo (4.5ha), em setembro de 1991, antes do corte e queima da vegetação para implantação dos sistemas, com uma biomassa média de 17 ton/ha, (McKERROW, 1992). E as espécies mais freqüentes encontradas nesta área foram: Borreria verticillata (L) G.F.G. Rolandra fruticosa (L) Kuntze, Laetia procera (Poeppig) Eichler, Vismia ssp e Brachiaria humidicola Rendle (remanescente da pastagem cultivada). 


\subsection{Descrição das pastagens e dos sistemas agroflorestais}

\subsubsection{Histórico das pastagens}

As áreas de pastagens abandonadas da Estação Experimental do Distrito Agropecuário da Suframa- EEDA/CPAA/EMBRAPA-Manaus, estão situadas no km 54 ao longo da Rodovia Manaus/Boa Vista (BR 174), ocupando uma superficie de aproximadamente 300 ha.

As atividades pastoris iniciaram-se em 1977, com derrubada, queima da vegetação nativa e preparo da área executada manualmente (sem uso de implemento agrícolas). As pastagens foram formadas com capim Quicuio da Amazônia, Brachiaria humidicola (Rendle) Sch., com baixa intensidade de pastejo, por aproximadamente 5 anos, degradadas parcialmente pela falta de manejo adequado (limpeza e adubação) e abandonadas gradativamente devido à baixa produtividade dos pastos, falta de interesse dos pesquisadores na manutenção da área e extinção da UEPAE/EMBRAPA-Manaus.

Desta área, foram selecionadas 10 ha para o estabelecimento dos sistemas agroflorestais (SAFs), com o seguinte histórico de manejo, de acordo com (McKERROW, 1992). O bloco I dos SAFs foi implantado em uma pastagem estabelecida em 1984, usada por 4 anos e abandonada em 1988. Em setembro de 1991, antes do corte, a capoeira apresentava uma biomassa de 14,4 ton/ha. O bloco II foi implantado em uma pastagem estabelecida em 1982, usada por 5 anos e abandonada em 1987, com biomassa de 21,6 ton/ha. O bloco III foi instalado em uma pastagem estabelecida em 1978 usada por 8 anos e abandonada em 1986, com biomassa de 14,8 ton/ha. 


\subsubsection{Delineamento estatístico dos Sistemas}

\section{Agroflorestais-SAFs.}

O ensaio com sistemas agroflorestais foi implantado em blocos ao acaso com 5 tratamentos e 3 repetições, com parcelas de $3000 \mathrm{~m}^{2}$ $(60,0 \mathrm{~m} \mathrm{X} \mathrm{50,0m)}$. Os SAFs escolhidos foram: SAF 1 = Sistema Agrosilvicultural I, (SAF 2) = Sistema Agrosilvicultural II, (SAF 3) = Sistema Agrosilvipastoril I e (SAF 4) = Sistema Agrosilvipastoril II (sistema com altos insumos) e a parcela Testemunha $=$ Pastagem abandonada (PA) . (Figura 2).

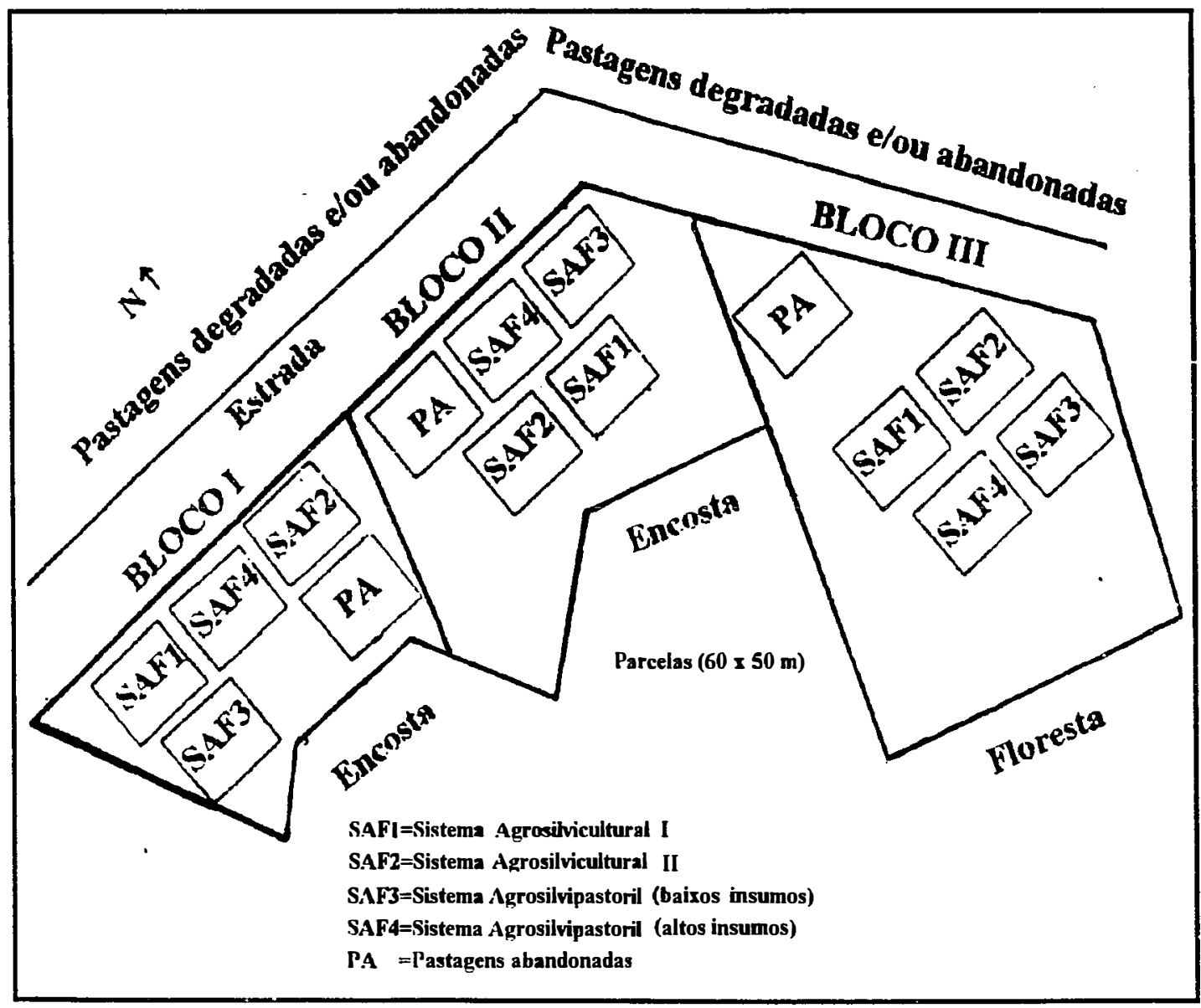

Figura 2 - Croqui com detalhe dos blocos e parcelas dos sistemas agroflorestais 
O SAF 1 tem por base as frutiferas perenes, com dois diferentes estratos aéreos e radiculares, enquanto o SAF 2 é baseado no multiestrato com aproveitamento dos recursos de produção em diferentes etapas, durante o desenvolvimento das espécies florestais e perenes. As culturas anuais (arroz e mandioca) e semi-perenes (mamão e maracujá) aproveitam intensivamente o máximo do potencial de produção. $\mathrm{Na}$ fase seguinte, as espécies que toleram sobreamento, como o araçá-boi e cupuaçu, devem aproveitar o espaço entre as árvores e constituirem um sub bosque produtivo.

Para os SAF 3 e SAF 4 a composição e o arranjo são semelhantes, diferenciando-se quanto ao manejo e preparo do solo; o SAF 3 é baseado no conceito de baixos insumos (low input agricultural), onde todas as atividades são manuais, com uso mínimo de adubação química $(20 \mathrm{~kg}$ de P/ha e se necessário, $20 \mathrm{~kg}$ de N/ha e $20 \mathrm{~kg}$ de $\mathrm{K} / \mathrm{ha}$, sem aplicação de defensivos agricolas.

O SAF 4 é baseado no conceito de altos insumos (high input), preparo do solo com implementos mecanizados, correção do solo com calcário (2t/ha) e adubação de acordo com as recomendação da cultura a ser plantada (milho), além do uso de defensivos agrícolas, quando necessário, contra pragas e doenças. As plantas invasoras em todos os sistemas foram controladas com capinas manuais.

Em todas as parcela dos SAFs foram plantados cerca viva de Gliricidia sepium (Jacq.) Walp.

\subsubsection{Composição dos sistemas agroflorestais}

SAF 1 - Sistema Agrosilvicultural I (Figura 3)

Os componentes do SAFl foram: Cupuaçu (Theobroma grandiflorum (S.) K. Schung.), Pupunha (Bactris gassipaes .Kunth) que foram plantados em março/1992, Açai (Euterpe oleraceae Mart.), implantadas em 
dezembro/1993. As entrelinhas foram ocupadas sequencialmente com Arroz (Oryza sativa L. var Xingu), Mandioca (Manihot esculenta Crantz.) e Mucuna (Mucuna pruriens (L.) DC.).

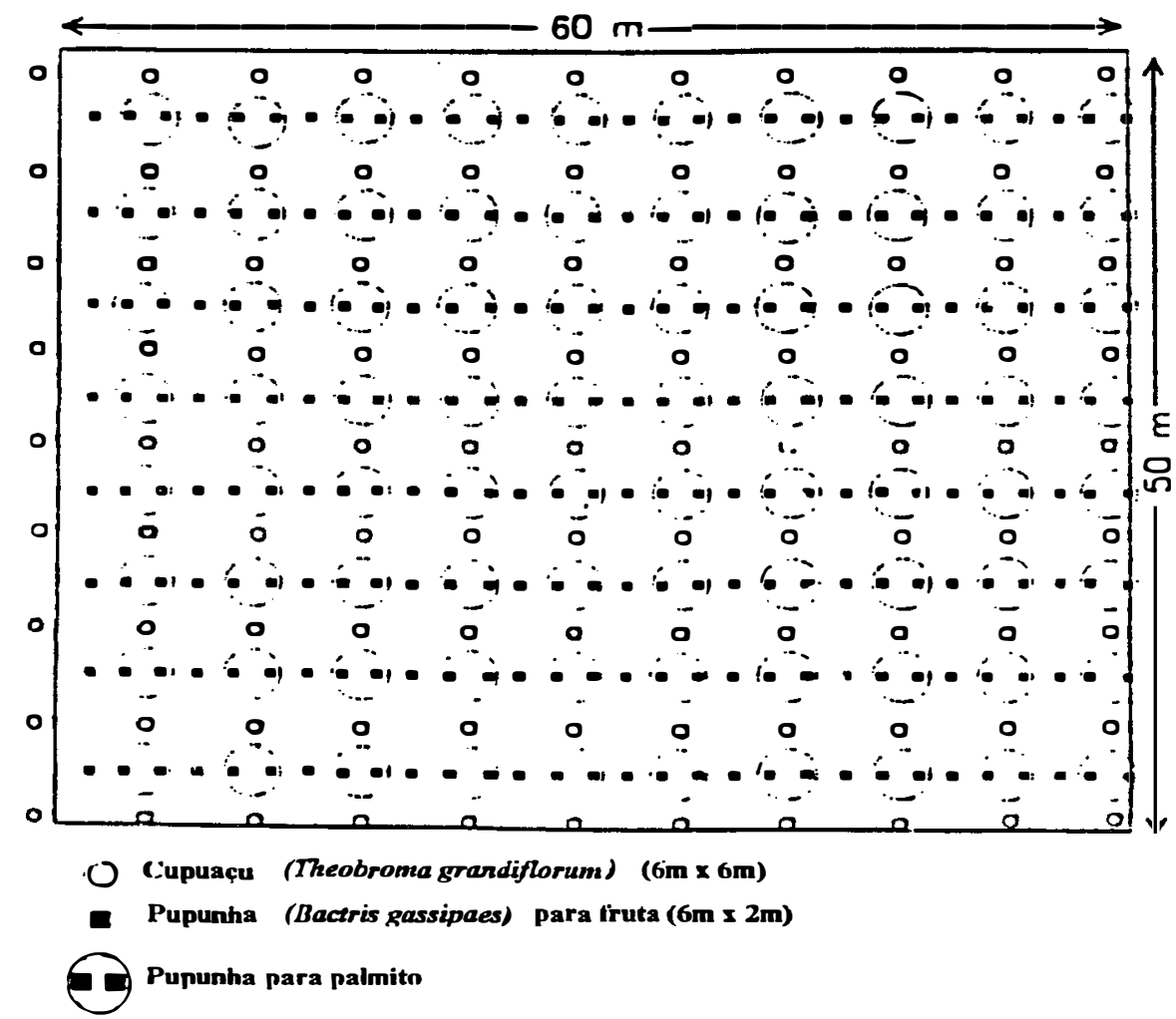

Figura 3 - Detalhe da parcela do Sistema Agrosilvicultural 1 - SAF1

SAF 2 - Sistema Agrosilvicultural II (Figura 3)

O SAF2 foi composto pelas seguintes espécies: Cupuaçu, plantando em maio/1992, Ingá (Inga edulis), plantado em dezembro/1992, Mogno (Swietenia macrophylla King), plantando em fevereiro/1993, Castanha-do-Brasil (Berthollettia excelsa H.B.K.) plantando em março/1993, Acerola (Malphigia emarginata L. ) e Mamão (Carica papaya L.) plantados em maio/1993, Genipapo (Genipa americana L.) e Teca (Tectona grandis) plantados em novembro/1993, Maracujá (Passiflora edulis L.) e Araçá-Boi (Eugenia stipitata McVaugh) plantados em março/1994. As entrelinhas foram ocupadas sequencialmente por arroz, mandioca e mucuna nos mesmos períodos do SAF1. 


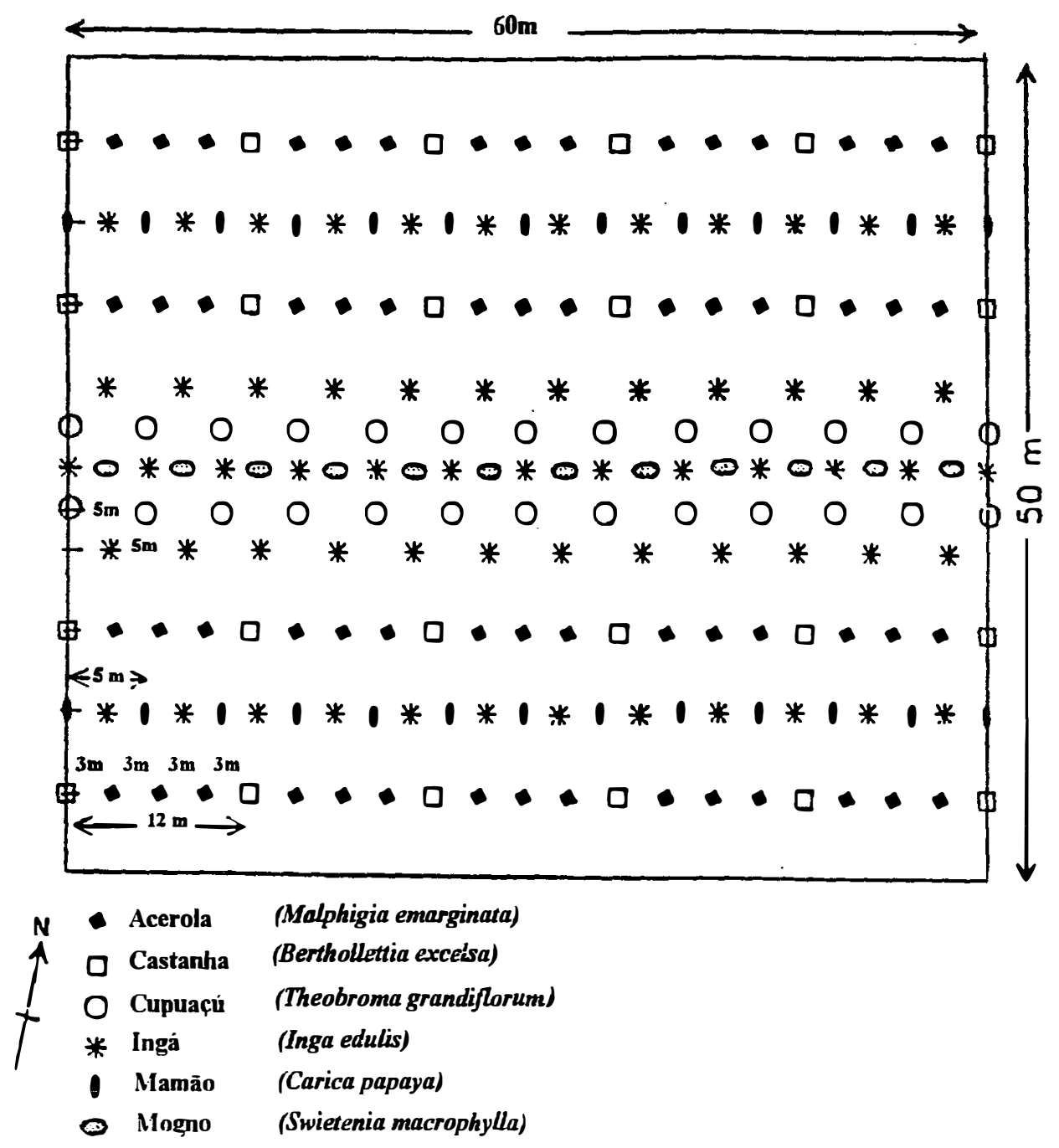

Figura 4 - Detalhe da parcela do sistema agrosilvicultural II - SAF2

SAF 3 - Sistema Agrosilvipastoril I (Figura 4)

No SAF3 o Ingá, Mogno e Paricá (Schizolobium amazonicum Ducke) foram plantados em linhas triplas em janeiro/1993. As faixas entre as linhas foram ocupadas por arroz, mandioca e mucuna, nos mesmos períodos do SAF2. Em janeiro/94 foi estabelecido o Desmodium ovalifolium. Wall. 


\section{SAF 4 - Sistema Agrosilvipastoril II (Figura 4)}

No SAF4 o Ingá, Mogno e Paricá, foram plantados em março/1993, no mesmo arranjo do SAF3. As faixas entre as linhas foram ocupadas com Milho (Zea mays L.), Caupi (Vigna unguiculata (L.) Walp.), Mandioca e Desmodio. O milho plantado em março/1992, não desenvolveu devido a falta de chuvas (fenomeno El niño). O solo ficou coberto com mucuna por um período de 5 meses (junho a novembro/1992), em novembro/92 foi preparado para novo plantio do milho (janeiro/93) e demais componentes.

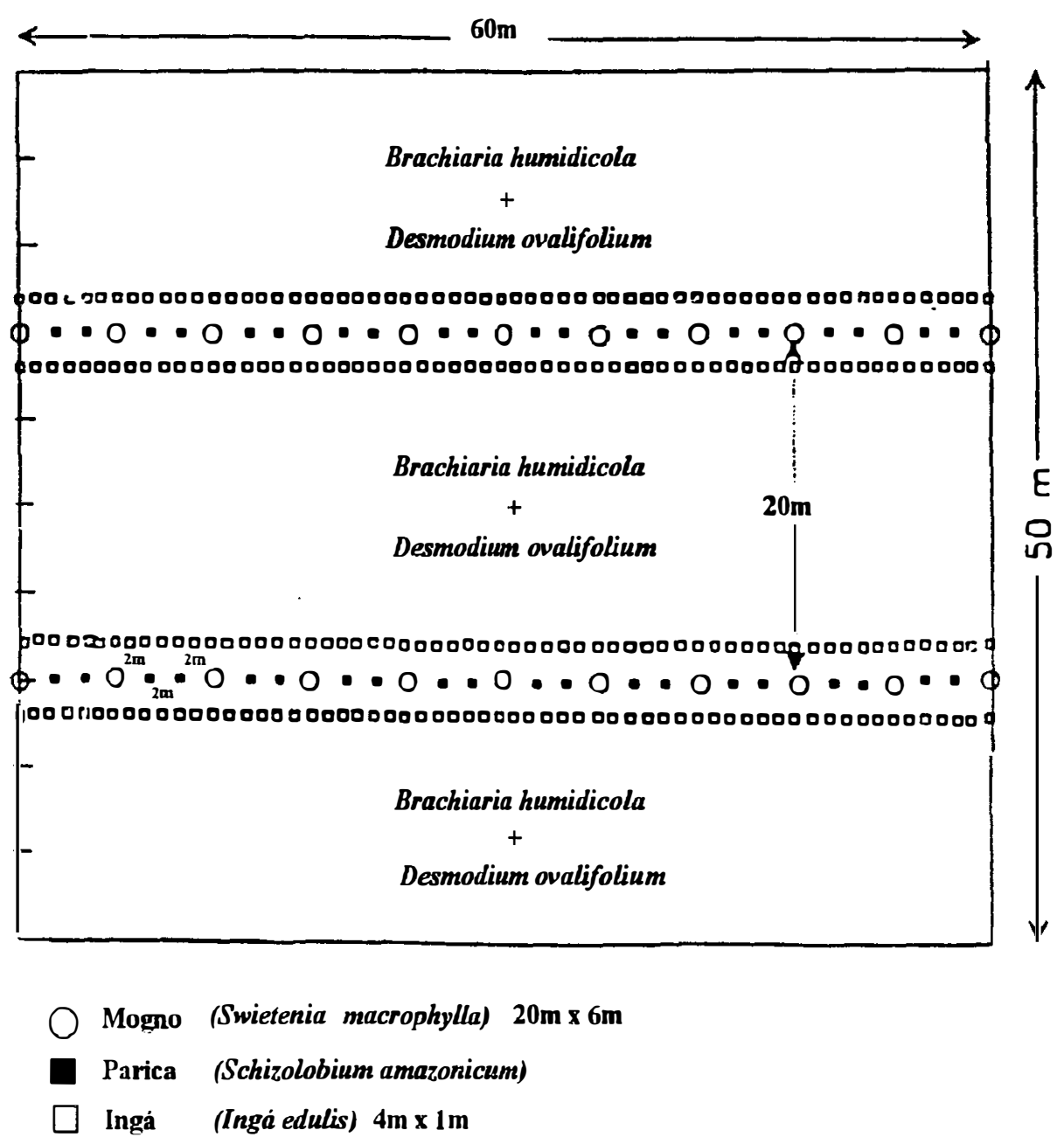

Figura 5 - Detalhe da parcela do sistema agrosilvipastoril - SAF3 e SAF4 
PA - Pastagem abandonada (Testemunha)

Parcela com vegetação secundária (capoeira de pastagem), formada principalmente por Borreria verticillata, Rolandra fruticosa, Vismia spp e Laetia procera.

\subsection{Obtenção dos dados}

\subsubsection{Descrição, demarcação e área de amostragens no campo}

As áreas de amostragens para coleta dos dados das plantas invasoras foram demarcadas dentro das parcelas de cada sistema (tratamento) do ensaio denominado "Sistemas Agroflorestais em Pastagens Degradadas". Para o presente estudo foi o delineamento experimental de blocos ao acaso com 4 tratamentos e 3 repetições, em 5 períodos de coletas. O levantamento na parcela sem cultivo (pastagem) foi realizado somente uma vez, em uma área de $300 \mathrm{~m}^{2}$, entre as parcelas cultivadas e a parcela da pastagem abandonada (borda), cuja vegetação foi cortada e queimada, quando do preparo da área dos sistemas ( Figura 6).

Os dados foram coletados numa áreas de $300 \mathrm{~m}^{2}(30,0 \mathrm{~m} \mathrm{X}$ $10,0 \mathrm{~m})$, onde foram amostrados ao acaso $3 \mathrm{~m}^{2}\left(12 \times 0,25 \mathrm{~m}^{2}\right)$ por parcela num total de 36 amostras $\left(0,25 \mathrm{~m}^{2}\right)$ por sistema e por período (12 amostras $\mathrm{X} 3$ blocos), em 5 coletas ao longo de 18 meses (Figura 6).

As 5 coletas foram realizadas nos meses de março/1993, junho/1993, setembro/1993, março/1994 e setembro/1994. Duas no período chuvoso (março) e duas no período menos chuvoso (setembro), e uma no final do período chuvoso (final de junho) e as coletas coincidiram com as capmas ou plantio dos componentes ou colheita das culturas anuais. 
As 12 amostragens foram distribuídas aleatoriamente dentro da área de $300 \mathrm{~m}^{2}$. Quando o ponto sorteado já tinha sido inventariado, era sorteado outro ponto (Figura 6)

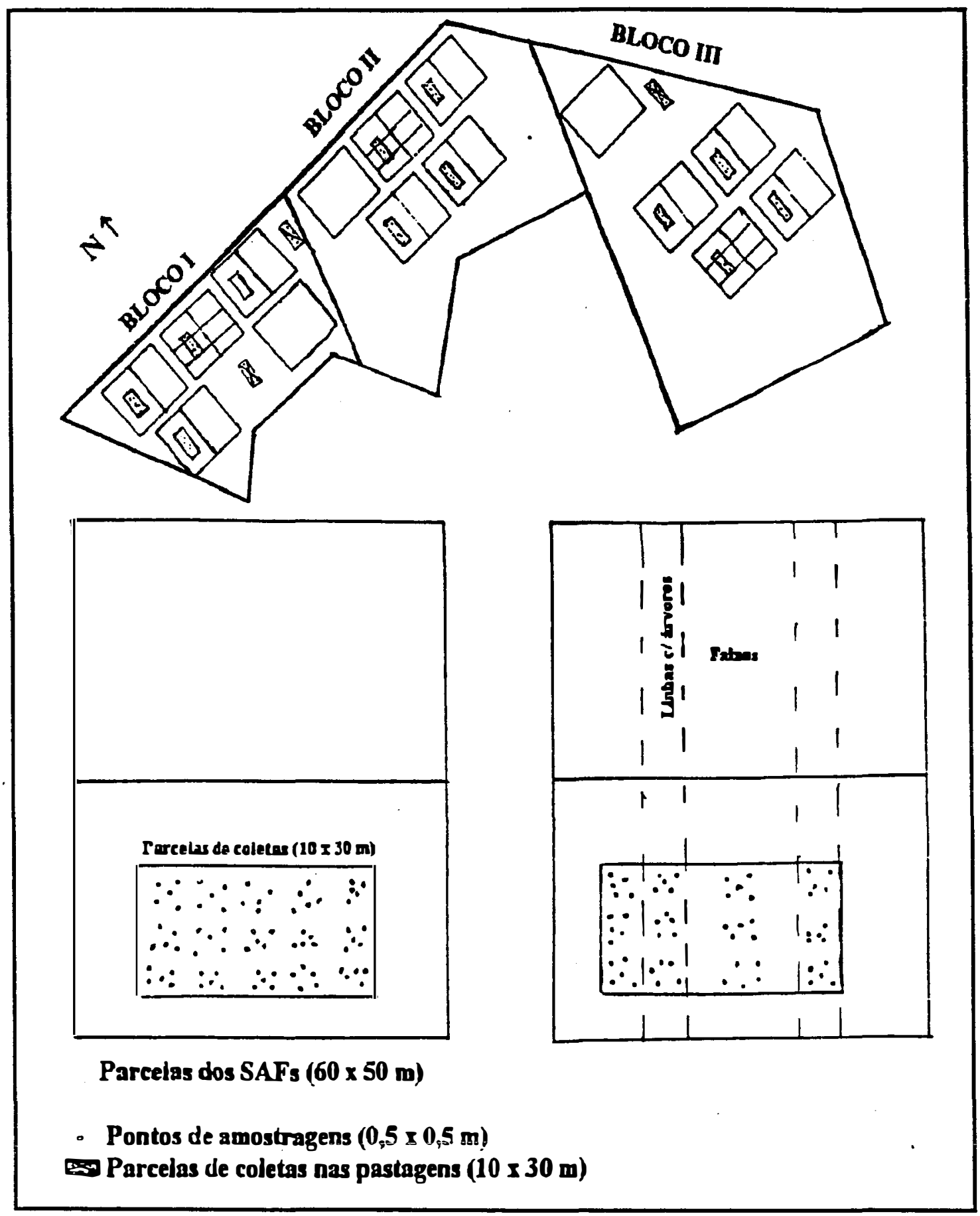

Figura 6 - Detalhe da parcela de coleta dos dados. 


\subsubsection{Coleta dos dados}

Em cada quadrado de $0,25 \mathrm{~m}^{2}(0,5 \times 0,5 \mathrm{~m})$, foram levantados os dados de número de indivíduos, número de espécies, tipo de regeneração (por sementes ou rebroto, originado do caule ou raiz) e estágio de desenvolvimento (plântula, jovem e adulta). Os indivíduos foram separados por espécie, tipo de germinação e estágio de desenvolvimento e registrados na planilha de coleta. Em seguida foram foram embalados por espécie em sacos de papel e levados para estufa a $70^{\circ} \mathrm{C}$ e tomado peso de matéria seca . Posteriormente foram preparadas amostras de cada espécie ou grupos (mono e dicotiledônea) de espécies (quando a amostra era muito pequena e não era possível fazer uma amostra por espécie) e enviados para Laboratório de Solos e Plantas do CPAA/EMBRAPA, para análise de macro nutrientes $(\mathrm{N}, \mathrm{P}, \mathrm{K}, \mathrm{Ca}$ e $\mathrm{Mg})$.

Para efeito de comparação da comunidade de plantas invasoras presentes nos sistemas com a das pastagem, foram coletados dados em uma parcela sem cultivo (pastagem) em uma única coleta, realizada no mês de dezembro de 1993, seguindo os mesmos critérios estabelecidos para os SAFs.

\subsubsection{Determinação do tipo de regeneração}

Foi considerada regeneração vegetativa rebrotando do caule quando o indivíduo apresentava sinais visíveis de poda ou corte raso (proveniente da capina com enxada). Rebroto do sistema radicular, quando era observado que a planta amostrada estava rebrotando de um prolongamento do sistema radicular de uma outra planta matriz. Portanto, antes da retirada da planta, a pessoa que estava fazendo a coleta, informava se a planta estava rebrotando do caule ou da raiz, ou de semente. Em caso de dúvida, a planta era retirada com a raiz para ser analisada se tinha ao não calo resultante do corte raso. Nos casos de rebroto por raiz, era 
observado se estava interligada a outra planta. Quando tinha a pivotante e não apresentava nenhum sinal de rebrotamento era considerada como uma planta originada de semente.

Para as gramíneas, com reprodução por rizomas e estolões e, outras espécies trepadeiras, ou com ramas prostradas, quando o seguimento ou parte vegetativa encontrava-se dentro do quadrado, e a planta matriz fora, cada seguimente (com capacidade de formar um novo indivíduo e completar o ciclo de vida), era considerado como um indivíduo, e um rebroto do caule. No caso da planta principal estar dentro do quadrado, as ramas que estavam fora eram eliminadas e, mesmo que possuísse mais de um seguimento (rizomas), era considerado como um indivíduo originado por semente.

\subsubsection{Determinação do estágio de desenvolvimento}

Para o estágio de desenvolvimento das plantas foram consideradas três fases: plântula, jovem e adulta. A "fase de plântula", refere-se àqueles indivíduos que apresentavam características próprias de uma plântula: folhas tenras, presença da folha primária, e/ou menores que $4 \mathrm{~cm}$ de altura, com ou sem 3 lançamentos foliares (principalmente as trepadeiras). "Plantas jovens" foram consideradas àquelas maiores que $4 \mathrm{~cm}$ de altura, com mais de 4 lançamentos foliares e sem indícios de floração. Para a "fase adulta", foram considerados todos os indivíduos que apresentavam indícios de floração e frutificação. Isto é, todos os indivíduos em fase de floração ou frutificação foram considerados como adultos, independente da altura. 


\subsubsection{Avaliação da fitomassa e análise foliar de macro nutrientes}

Para obtenção do peso da matéria seca de biomassa das invasoras, foi considerado somente a parte aérea da planta, pequenas raízes ou pedaços de rizomas que acompanhavam as amostras, principalmente dos capins e daqueles que se propagam por estolões.

Para a determinação de nitrogênio, foi usado o método volumétrico de Kjeldahl usando-se o aparelho de microdestilação, para extração fósforo, o método de Murphy \& Riley (1962), para o potássio a fotometria de chama, cálcio e magnésio foram determinados por espectrofotometria de absorção atômica. Os resultados das análises foram expressos em porcentagem.

\subsubsection{Identificação das espécies}

Inicialmente foi realizada uma coleta preliminar (junho/92) . das diferentes espécies ocorrentes na área e, com ajuda dos operários rurais (caboclo da região) foram determinados os nomes vulgares. Em seguida foram comparadas com as descrições, monografias e manuais de plantas invasoras como: LORENZI (1986, 1991 e 1994); ARANHA et.al. (1987); ALBUQUERQUE (1978 e 1987); DIAS FILHO (1990); LEITÃO FILHO et al. (1972) e KISSMANN. \& GROTH (1992). As espécies que não foram possíveis de serem identificadas através deste método foram herborizadas e levadas ao INPA (Instituto Nacional de Pesquisa da Amazônia) para serem identificadas pela equipe da curadoria do Herbário. Quando não foi possível a identificação de espécies. estas foram citadas ao nível de gênero ou família.

Em seguida, foi elaborado uma relação com o nome vulgar e nome científico, além de um álbum contendo uma amostra de cada espécie 
ocorrente na área, o qual era levado para o campo durante as coletas. No decorrer das coletas foram aparecendo novas espécies, que eram incorporadas no acervo.

No caso de sinonímia, para a mesma espécie, como as espécies descritas por LORENZI (1986), ou citados por outros autores, ou no herbário do INPA, o nome usado foi aquele aceito ou citado pelos autores da região, como DANTAS \& RODRIGUES (1980); ALBUQUERQUE (1978 e 1987); DIAS FILHO(1990); SILVA et.al. (1977).

Duplicata de todas as espécie foram depositadas no herbário do Departamento de Botânica da ESALQ/USP, e no herbário do CPAA/EMBRAPA/MANAUS-AM.

\subsection{Análise dos dados}

Os dados foram transformados em $\operatorname{Ln}(\mathrm{x})$ e as análise dos parâmetros densidade, fitomassa e frequência das espécies foram obtidos através de análises estatísticas realizadas através do procedimento do GLM do SAS versão 6.04. Também foram calculados os índices de diversidade de Shannon Weaver (H) e de similaridade de Jaccard (ISJ).

O uso do parâmetro densidade, é visto com restrições, para este tipo de vegetação, devido a dificuldade de contar os pequenos indivíduos e devido a variação de tamanho e da forma das gramíneas (OOSTING, 1956). Além disso, ocorre também o problema da heterocedasticidade dos dados, em função da ocorrência de populações numerosas e outras com poucos indivíduos. Diante deste fato é sugerida a transformação dos dados para serem analisados (BANZATTO \& KRONKA, 1992) mas que nem sempre satisfazem as hipóteses básicas para as análises das variâncias. 


\subsubsection{Determinação dos parâmetros fitossociológicos}

A determinação da densidade foi definida como número de indivíduos por metro quadrado. Este indice refere-se ao número de individuos de cada espécie, dentro de uma comunidade vegetal por unidade de área. A "densidade absoluta", indica o número total de indivíduos de uma determinada espécie por unidade de área.

$$
\begin{aligned}
& \mathrm{DAi}=\mathrm{ni} / \mathrm{m}^{2} \\
& \mathrm{DAi}=\text { densidade absoluta }\left(\mathrm{m}^{2}\right) \\
& \mathrm{ni}=\text { número total de indivíduos amostrados de uma dada } \\
& \text { espécie } \mathrm{i} \\
& \mathrm{m}^{2}=\text { metros quadrados }
\end{aligned}
$$

A "densidade relativa", indica a porcentagem do número de indivíduo de uma determinada espécie em relação ao total de indivíduos de todas as espécies identificadas no levantamento da área.

$$
\mathrm{DRi}=\mathrm{DAni} / \mathrm{N} \times 100
$$

$\mathrm{DRi}=$ densidade relativa $(\%)$

DAni $=$ densidade absoluta da especie $\mathrm{i}\left(\mathrm{n} / \mathrm{m}^{2}\right)$

$\mathrm{N}=$ número total de indivíduos amostrados, de todas as

espécies do levantamento por $\mathrm{m}^{2}$

A frequência expressa o conceito estatístico relacionado com a uniformidade de distribuição horizontal de cada espécie na área, caracterizando a ocorrência das mesmas dentro das parcelas em que ela ocorre. A "frequência absoluta", é a porcentagem de parcelas em que cada espécie ocorre.

$$
\mathrm{FAi}=\mathrm{Npi} / \mathrm{Ntp} \times 100
$$


$\mathrm{FAi}=$ frequência absoluta $(\%)$

$\mathrm{Npi}=$ número de parcelas em que ocorre uma dada espécie i

Ntp = número total de parcelas amostradas

A "frequência relativa" é a porcentagem de ocorrência de uma espécie em relação à soma das frequências absolutas de todas as espécies.

$\mathrm{FRi}=\mathrm{FAi} / \Sigma \mathrm{FA} \mathrm{X} 100$

$\mathrm{FRi}=$ frequência relativa da espécie i (\%)

$\mathrm{FAi}=$ frequência absoluta da espécie i $(\%)$

$\Sigma \mathrm{FA}=$ frequência absoluta de todas as espécies

Para o cálculo da "frequência" foi levado em conta 36 parcelas de $0,25 \mathrm{~m}^{2}$

A fitomassa, foi definida como o peso da matéria seca da fitomassa aérea em gramas por metro quadrado. A "fitomassa absoluta" indica o peso em gramas, da matéria seca da fitomassa área de todos os indivíduos de uma determinada espécie por metro quadrado.

$$
\begin{aligned}
& \text { FTAi }=\mathrm{gi} / \mathrm{m}^{2} \\
& \text { FTAi }=\text { fitomassa absoiuta }\left(\mathrm{g} / \mathrm{m}^{2}\right) \\
& \text { gi }=\text { peso total em gramas da fitomassa aérea de uma dada } \\
& \text { espécie } \mathrm{i}
\end{aligned}
$$

A "fitomassa relativa" é a porcentagem do peso da fitomassa de uma determinada espécie em relação ao peso total de todas as espécies registradas no levantamento.

$\mathrm{FTRi}=\mathrm{FTAi} / \mathrm{G} \times 100$

FTRi $=$ fitomassa relativa da espécie i $(\%)$ 
FTAi $=$ fitomassa absoluta da espécie $\mathrm{i}\left(\mathrm{g} / \mathrm{m}^{2}\right)$

$\mathrm{G}=$ peso total de todos os indivíduos amostrados, de todas as espécies do levantamento

O índice de valor de importância (IVI) é um índice que combina os valores relativos dos dados a fim de conferir uma nota global para cada espécie da comunidade vegetal.O I.V.I, foi calculado com base na densidade relativa, fitomassa relativa e frequência relativa.

$I V I i=D R i+F R i+F T R i$

IVIi = indice de valor de importância de uma dada espécie i

$\mathrm{DRi}=$ densidade relativa de uma dada espécie i (\%)

$\mathrm{FRi}=$ frequência relativa de uma dada espécie i (\%)

FTRi $=$ fitomassa relativa de uma dada espécie i (\%)

O padrão de distribuição das espécies foi determinado pelo (Imc) índice de McGinnies (1982)

$\mathrm{IMci}=\mathrm{DRi} / \mathrm{di}$

IMci = índice de McGinnies para uma dada espécie i (\%)

$\mathrm{DRi}=$ densidade relativa de uma dada espécie i (\%)

$\mathrm{di}=\operatorname{Ln}(1 \times \mathrm{FAi} / 100)$

$\mathrm{Ln}=$ logaritmo neperiano

$\mathrm{FAi}=$ frequência absoluta de uma dada espécie $\mathrm{i}(\%)$

Quando IMc for $>=2$ as espécies tem distribuição agrupada, $>=0,5$ e $<2$ distribuição aleatória e $<0,5$ ditribuição uniforme. 
$\mathrm{O}$ índice de diversidade de Shannon Weaver ( $\left.\mathrm{H}^{\prime}\right)$ foi usado para indicar a diversidade de espécies das diferentes comunidades vegetais.

$\mathrm{H}^{\prime}=-\Sigma \mathrm{Pi} \times \operatorname{Ln} \mathrm{Pi}$

$\mathrm{H}^{\prime}=$ indice de diversidade de Shannon Weaver

$\mathrm{Pi}=$ ni / $\mathrm{N}=$ relação entre o número de indivíduos da espécie

(ni) e o número total de indivíduos $(\mathrm{N})$.

$\mathrm{J}=\mathrm{H}^{\prime} / \mathrm{Hmax}$

Onde, $\mathrm{J}=$ equabilidade

$\operatorname{Hmax}=\operatorname{Ln}(S)$

$\mathrm{S}=$ número total de espécies.

$\mathrm{O}$ índice de similaridade de Jaccard (ISJ) foi usado para avaliar a composicão floristica entre as diversas áreas amostradas.

$\operatorname{ISJ}_{(\mathrm{A}, \mathrm{B})}=\mathrm{C} /(\mathrm{A}+\mathrm{B}-\mathrm{C}) \times 100$

$\operatorname{ISJ}_{(A, B)}=$ índice de similaridade de Jaccard entre a área A e $\mathrm{B}$

$\mathrm{C}=$ número de espécies comuns nas áreas $\mathrm{A}$ e $\mathrm{B}$

$\mathrm{A}=$ número de espécies da comunidade $\mathrm{A}$

$\mathrm{B}=$ número de espécies da comunidade $\mathrm{B}$ 


\section{RESULTADOS E DISCUSSÃO}

\subsection{Caracterização da Comunidade de Plantas Invasoras nos Sistemas}

\subsubsection{Composição, estrutura e regeneração da comunidade de plantas invasoras}

\subsubsection{Composição florística da comunidade}

Durante os 18 meses de estudo (mar/93-set/94), nos 5 levantamentos florísticos da comunidade de plantas invasoras ocorrentes em sistemas agroflorestais implantados em pastagens degradadas na Amazônia Ocidental, registrou-se um total de 40 gêneros, distribuídos em 63 espécies e 18 familias botânicas (Tabela 4).

As famílias com maior número de espécies foram as Poaceae (17), Asteraceae (7), Cyperaceae (7), Solanaceae(5) e Euphorbiaceae (5), sendo que as demais famílias apresentaram de 1 a 4 espécies.

Com referência ao hábito de crescimento, $81 \%$ das espécies foram consideradas herbáceas (h), $11 \%$ arbustivas (b); de acordo com ALBUQUERQUE (1978); SILVA et. al.(1977); 3\% cipós e $5 \%$ arbóreas. Quanto às arbóreas, Cecropia sp foi encontrada regenerando por semente, Tabebuia sp por rebrotação da raiz de árvores da antiga capoeira e Vismia cayennensis por sementes e rebrotação.

Do total de 63 espécies, 26 são monocotiledôneas e 37 dicotiledôneas. As familias Asteraceae seguida das Solanaceae e Euphorbiaceae contribuíram com $28 \%$ do total das espécies para o grupo das dicotiledôneas, enquanto que o grupo das monocotiledôneas era formado por 
somente 3 famílias, (Poaceae, Cyperaceae e Commelinaceae), representando $40 \%$ do total das espécies registradas na área de estudo.

Tabela 4- Lista das espécies, com as respectivas familias, nome vulgar e hábito de crescimento.

\begin{tabular}{|c|c|c|c|}
\hline $\begin{array}{l}\text { FAMILIA / } \\
\text { ESPÉCIE } \\
\end{array}$ & NOME VULGAR & $\begin{array}{l}\text { HABT. } \\
\text { CRESC. }\end{array}$ & GRUPO \\
\hline \multicolumn{4}{|l|}{ AMARANTACEAE } \\
\hline Alternanthera ficoidea (L.) R. Br. & Apaga fogo & h & D \\
\hline ASTERACEAE & & $\mathbf{h}$ & \\
\hline Acanthospermum australe (Loefl.) O Kuntze & Carrapicho de carneiro & & D \\
\hline Ageratum conyzoides $\mathrm{L}$. & Catinga de bode & $\mathbf{h}$ & D \\
\hline Erigeron bonariensis L. & Rabo de foguete & $\mathbf{h}$ & D \\
\hline Emilia sagitatta (Vahl.) D.C & Pincel amarelo & $\mathbf{h}$ & D \\
\hline Emilia sonchifolia D.C. & Pincel vermelho & $\mathbf{h}$ & D \\
\hline Orthopappus angustifolius (Sw.) Gleason & Fumo bravo & h & D \\
\hline Rolandra fruticosa (L.) Kuntze & Estripe & $\mathbf{h}$ & D \\
\hline Composita (Asteracea) (sp4) & Verônica & $\mathbf{h}$ & D \\
\hline \multicolumn{4}{|l|}{ BIGNONIACEAE } \\
\hline Tabebuia sp & Pau d'arco & a & D \\
\hline \multicolumn{4}{|l|}{ CECROPIACEAE } \\
\hline Cecropia sp & Embaúba & $\mathbf{a}$ & D \\
\hline \multicolumn{4}{|l|}{ CLUSIACEAE } \\
\hline Vismia cayennensis (Jacq.) Pres & Lacre branco & a & D \\
\hline Vismia sp. & Lacre vermelho & b & D \\
\hline \multicolumn{4}{|l|}{ COMMELINACEAE } \\
\hline Commelina benghalensis L. & Trapoeraba 1 & h & $\mathbf{M}$ \\
\hline Commelina sp. & Trapoeraba.2 & $\mathbf{h}$ & $\mathbf{M}$ \\
\hline \multicolumn{4}{|l|}{ CYPERACEAE } \\
\hline Cyperus diffusus Vahl & Tiririca branca & $\mathbf{h}$ & $\mathbf{M}$ \\
\hline Cyperus distans Vahl & Tiririca & $\mathbf{h}$ & $\mathbf{M}$ \\
\hline Cyperus sp & Tiririca & h & $\mathbf{M}$ \\
\hline Dichromena ciliata Vahl & Capim estrela & h & $\mathbf{M}$ \\
\hline Fimbristylis annua Roem \& Schult & & h & $\mathbf{M}$ \\
\hline Fimbristylis sp. & & $\mathbf{h}$ & $\mathbf{M}$ \\
\hline Scleria secans (L.) Urban & Alpiste do mato & $\mathbf{h}$ & $\mathbf{M}$ \\
\hline \multicolumn{4}{|l|}{ EUPHORBIACEAE } \\
\hline Crotum lobatus $\mathrm{L}$. & & $\mathbf{h}$ & D \\
\hline Euphorbia hyssopifolia (L.) Small & & $\mathbf{h}$ & D \\
\hline Euphorbia pilulifera L. & & $\mathbf{h}$ & D \\
\hline Euphorbia prostrata Ait. & & $\mathbf{h}$ & D \\
\hline Phyllanthus niruri L. & & $\mathbf{h}$ & D \\
\hline \multicolumn{4}{|l|}{ FABACEAE } \\
\hline Calopogonium muconoides Dev. & Calopogonio & c & D \\
\hline Dalbergia sp & Cipo de ferro & c & D \\
\hline FABACEAE (sp5) & & b & D \\
\hline \multicolumn{4}{|l|}{ MALVACEAE } \\
\hline Sida glaziovii K. Schum. & Guanxuma branca & h & D \\
\hline Sida rhombifolia L. & Guanxuma & h & D \\
\hline \multicolumn{4}{|l|}{ MELASTOMATACEAE } \\
\hline $\begin{array}{l}\text { Clidemia hirta L. } \\
\text { MTMOSACEAF }\end{array}$ & & $\mathrm{h}$ & D \\
\hline
\end{tabular}


Mimosa pudica L.

MIRTACEAE

Mirtacia (sp3)

PIPERACEAE

Piper aducam L

POACEAE

Brachiaria humidicola (Rend.) Sch.

Brachiaria plantaginea (L.) Hitch.

Brachiaria sp

Capim (sp1)

Digitaria sanguinalis

Digitaria sp

Digitaria sp 2

Eleusine indica (L.) Gaertn.

verticillata (L.) Beauv.

Eragrostis sp

Sorghum halepense (L.) Pers.

Homolepis aturensis (H.B.K.) Chase.

Paspalum conjugatum Berg.

Paspalum multicaule Poir

Paspalum sp

Paspalum virgatum L.

Digitaria insularis (L.) Mez Xe Ekman

RUBIACEAE

Borreria alata Dc.

Borreria latifolia (Aubl.) K. Schum.

Borreria verticillata (L.) ..G.F.W.Meyer

SOLANACEAE

Physalis angulata L.

Physalis pubescens L.

Solanum grandiflorum Ruiz. \& Pav.

Solanum juripeba Rich.

Solanum rugosum Dunal

VERBENACEAE

Lantana camara L.

Stachvtarpheta cavennensis (J.) Pers.
Malicia

h

D

b $\quad$ D

Pimenteira b

Quicuio da Amazônia h

Capim braquiaria

Capim

Capim digitaria

Capim digitaria 2

Capim pé de galinha

Capim milhã

Capim massambará

Capim pacuam

Capim roxinho

Capinzinho

Capim Taripucu

Capim amargoso

Vassourinha

Erva de lagarto

Vassourinha de botão

Camapu 1

Camapu 2

Jurubebão

Jurubebinha

Coça - coça

Chumbinho

Gervão
M

M

M

M

$\mathbf{M}$

M

M

M

$\mathbf{M}$

M

M

M

M

M

M

M

D

h D

h D

h D

h D

b D

h D

b D

b D

h
M
$M$
$M$
$M$
$M$
$M$
$M$
$M$
$M$
$M$
$M$
$M$
$M$
$M$
D
D
D
D
D
D
D
D
D
D

(D) dicotiledônea, (M) monocotiledônea, (a) arbórea, (b) arbustiva, (c) cipó e (h) herbácea

A presença do número de espécies dicotiledôneas para a composição florística da comunidade invasora foi maior $(60 \%)$ do que das monocotiledôneas, enquanto que para os demais parâmetros, como número de indivíduos por $\mathrm{m}^{2}$, freqüência $\mathrm{e}$ peso da fitomassa aérea, foram as monocotiledoneas que se destacaram. Entretanto, de acordo com a Figura 7, verifica-se uma tendência do aumento no número de espécies dicotiledôneas e uma estabilização das monocotiledôneas. 


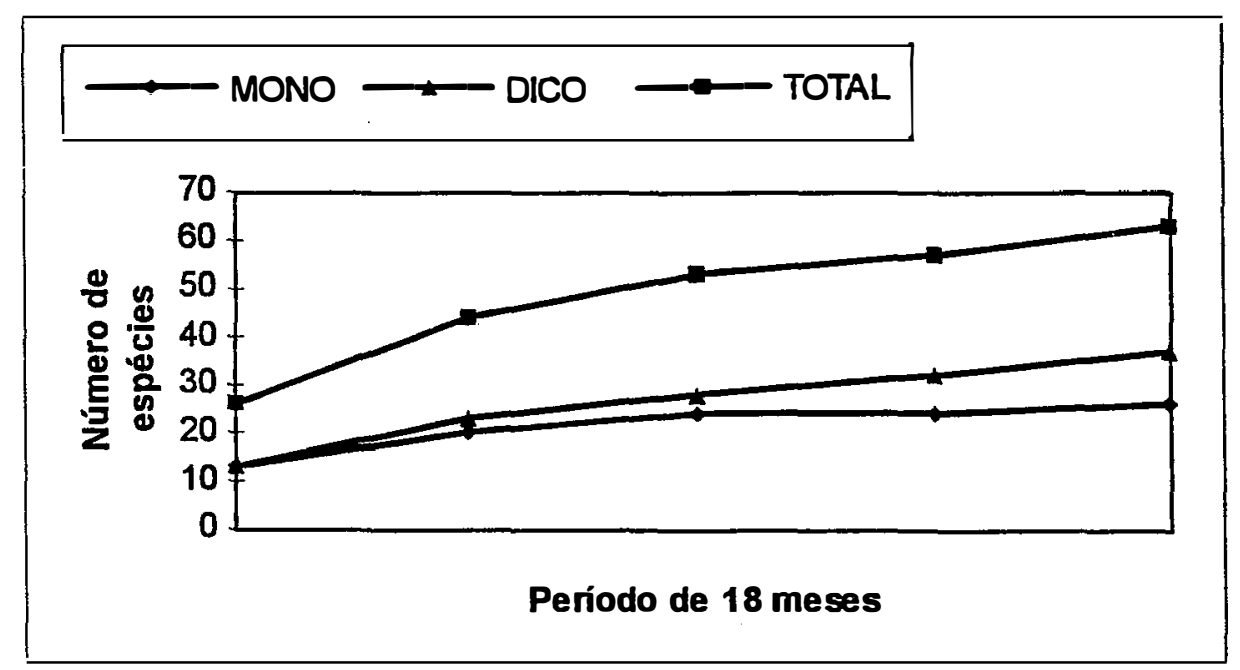

Figura 7 - Número acumulado de espécies (monocotiledôneas e dicotiledôneas) ocorrentes nos sistemas agroflorestais, durante 18 meses de coletas.

O aumento de dicotiledôneas em áreas agrícolas freqüentemente aradas tem sido observada por diversos autores como ALBUQUERQUE (1978), DERKSEN et al. (1993), entre outros. Essa tendência segundo FROUD-WILLIAMS (1983), está associada à maior diversidade de espécies dicotiledôneas, em cujo grupo encontra-se a maioria das famílias botânicas consideradas por ZINDAL (1980) como as mais importantes e agressivas plantas invasoras das áreas cultivadas.

\subsubsection{Estrutura da comunidade}

Na Tabela 5, observa-se os parâmetros de densidade, freqüência. fitomassa absoluta e relativa, Índice de Valor de Importância e padrão de distribuição das espécies segundo o Índice de McGinnnies que caracterizam a estrutura horizontal da vegetação secundária invasora.

De acordo com índice de valor de importância (I.V.I.), verifica-se que as 10 primeiras espécies de maior importância foram das famílias Poaceae, Cyperaceae, Solanaceae, Rubiaceae e Verbenaceae. Sendo a primeira representada por 6 espécies e as demais com somente uma espécie; apresentando $78,43 \%$ do valor de importância do total das espécies registradas. 
Juntas totalizaram $70,00 \%$ da freqüência relativa das espécies, $86,02 \%$ da densidade relativa e acumularam um total de $79,46 \%$ da Fitomassa relativa.

Tabela 5 - Parâmetros fitossociológico; densidade absoluta - DA $\left(\mathrm{m}^{2}\right)$, densidade relativa - DR(\%), freqüência absoluta - FA, freqüência relativa - FR (\%), fitomassa absoluta - FTA $\left(\mathrm{g} / \mathrm{m}^{2}\right)$, fitomassa relativa - FTR (\%), índice de McGinnies - I.Mc (padrão de distribuição das espécies) e índice de valor de importância -. I.V.I.; das espécies presentes nos sistemas.

\begin{tabular}{|c|c|c|c|c|c|c|c|c|}
\hline ESPÉCIES & $\mathrm{DA}\left(\mathrm{m}^{2}\right)$ & $\mathrm{DR}(\%)$ & FA & FR(\%) & FTA $\left(g / \mathrm{m}^{2}\right)$ & \begin{tabular}{|l|}
$\operatorname{FTR}(\%)$ \\
\end{tabular} & I.Mc. & I.V.I \\
\hline Fimbristylis annua & \begin{tabular}{|l|}
16.23 \\
\end{tabular} & 23.56 & 66.67 & 15.98 & 9.54 & \begin{tabular}{|r|}
9.40 \\
\end{tabular} & $(14.02)$ & 16.31 \\
\hline Solanum juripeba & 2.97 & 4.32 & 41.11 & 9.85 & 16.86 & 16.60 & (1.97) & 10.26 \\
\hline Brachiaria humidicola & 4.15 & 6.02 & 36.67 & 8.79 & 16.63 & 16.37 & $(2.60)$ & 10.39 \\
\hline Paspalum multicaule & 15.66 & 22.74 & 17.92 & 4.29 & 5.99 & 5.90 & $(7.63)$ & 10.98 \\
\hline Paspalum conjugatum & 5.03 & 7.31 & 28.61 & 6.86 & 11.09 & 10.92 & $(2.84)$ & 8.36 \\
\hline Borreria verticillata & 1.84 & 2.68 & 40.42 & 9.69 & 5.41 & 5.32 & (1.24) & 5.90 \\
\hline Paspalum sp. & 8.01 & 11.64 & 22.64 & 5.43 & 4.92 & 4.85 & $(4.01)$ & 7.30 \\
\hline Digitaria sp. & 2.67 & 3.88 & 13.61 & 3.26 & 3.40 & 3.35 & (1.12) & 3.50 \\
\hline S. cavennensis & 0.52 & 0.75 & 13.47 & 3.23 & 3.03 & 2.99 & $(0.23)$ & 2.32 \\
\hline Homolepis aturensis & 2.15 & 3.12 & 10.28 & 2.46 & 3.81 & 3.76 & $(0.82)$ & 3.11 \\
\hline Physalis angulata & 0.23 & 0.33 & 11.11 & 2.66 & 1.19 & 1.17 & $(0.10)$ & 1.39 \\
\hline Solanum rugosum & 0.21 & 0.31 & 8.89 & 2.13 & 1.14 & 1.12 & $(0.08)$ & 1.19 \\
\hline Sida rhombifolia & 0.50 & 0.73 & 5.56 & 1.33 & 1.88 & 1.85 & $(0.18)$ & 1.30 \\
\hline C. muconoides & 0.15 & 0.22 & 4.58 & 1.10 & 0.76 & 0.75 & $(0.05)$ & 0.69 \\
\hline Commelina sp & 0.58 & 0.84 & 5.00 & 1.20 & 3.92 & 3.86 & $(0.19)$ & 1.97 \\
\hline Digitaria (sp 2) & 0.73 & 1.06 & 2.41 & 0.58 & 1.42 & 1.40 & $(0.21)$ & 1.01 \\
\hline Capim ( sp 1) & 3.27) & 4.74 & 3.33 & 0.80 & 1.02 & 1.00 & $(0.95)$ & 2.18 \\
\hline C.benghalensis & 0.03 & 0.04 & 4.44 & 1.07 & 0.25 & 0.25 & $(0.01)$ & 0.45 \\
\hline Rolandra fruticosa & 0.25 & 0.36 & 5.83 & 1.40 & 0.98 & 0.97 & $(0.09)$ & 0.91 \\
\hline Brachiaria planiaginea & 0.71 & 1.03 & 7.92 & 1.90 & 0.54 & 0.54 & $(0.26)$ & 1.15 \\
\hline Borreria latifolia & 0.13 & 0.19 & 3.33 & 0.80 & 0.62 & 0.61 & $(0.04)$ & 0.53 \\
\hline Brachiaria sp. & 0.06 & 0.09 & 3.89 & 0.93 & 1.11 & 1.10 & $(0.02)$ & 0.71 \\
\hline Sorghum halepense & 0.62 & 0.90 & +.26 & 1.02 & 0.47 & 0.46 & $(0.19)$ & 0.79 \\
\hline Lantana camara & 0.01 & 0.02 & 0.74 & 0.18 & 0.13 & 0.13 & & 0.11 \\
\hline Tabebuia sp. & 0.01 & 0.01 & 1.67 & 0.40 & 0.62 & 0.61 & -1 & 0.34 \\
\hline Eragrostis sp. & 0.42 & 0.61 & 2.59 & 0.62 & 0.20 & 0.20 & $(0.12)$ & 0.48 \\
\hline Euphorbia prostrata & 0.19 & 0.27 & 2.78 & 0.67 & 0.29 & 0.28 & $(0.05)$ & 0.41 \\
\hline Vismia cavennensis & 0.01 & 0.01 & 1.67 & 0.40 & 0.30 & 0.29 & & 0.23 \\
\hline Emila sonchifolia & 0.07 & 0.11 & 3.06 & 0.73 & 0.37 & 0.36 & $(0.02)$ & 0.40 \\
\hline Physalis pubescens & 0.02 & 0.03 & 3.33 & 0.80 & 0.12 & 0.11 & $(0.01)$ & 0.31 \\
\hline Emilia sagitatta & 0.12 & 0.17 & 3.61 & 0.87 & 0.68 & 0.67 & $(0.03)$ & 0.57 \\
\hline Alternanthera ficoidea & 0.05 & 0.07 & 2.22 & 0.53 & 0.41 & 0.40 & $(0.01)$ & 0.34 \\
\hline Paspalum virgatum & 0.02 & 0.03 & 2.22 & 0.53 & 0.19 & 0.19 & $(0.01)$ & 0.25 \\
\hline Cyperus distans & 0.30 & 0.43 & 1.67 & 0.40 & 0.19 & 0.18 & $(0.08)$ & 0.34 \\
\hline Eleusine indica & 0.03 & 0.05 & 1.48 & 0.36 & 0.16 & 0.15 & $(0.01)$ & 0.19 \\
\hline Euphorbia pilulifera & 0.02 & 0.02 & 1.67 & 0.40 & 0.04 & 0.04 & & 0.15 \\
\hline A. australe & 0.07 & 0.11 & 1.67 & 0.40 & 0.33 & 0.33 & $(0.02)$ & 0.28 \\
\hline
\end{tabular}




\begin{tabular}{|c|c|c|c|c|c|c|c|c|}
\hline Digitaria insularis & 0.03 & 0.04 & 1.11 & 0.27 & 0.18 & 0.18 & $(0.01)$ & 0.167 \\
\hline Fimbristylis sp & 0.29 & 0.42 & 1.81 & 0.43 & 0.03 & 0.03 & $(0.08)$ & 0.29 \\
\hline Borreria alata & 0.04 & 0.06 & 1.67 & 0.40 & 0.17 & 0.17 & $(0.01)$ & $0.2 \mathrm{~T}$ \\
\hline Euphorbia hyssopifolia & 0.04 & 0.05 & 1.39 & 0.33 & 0.24 & 0.23 & $(0.01)$ & 0.21 \\
\hline Setaria verticillata & 0.07 & 0.11 & 1.39 & 0.33 & 0.05 & 0.05 & $(0.02)$ & ग.16 \\
\hline Cyperus diffusus & 0.10 & 0.15 & 1.39 & 0.33 & 0.06 & 0.06 & $(0.03)$ & 0.18 \\
\hline Dichromena ciliata & 0.06 & 0.09 & 1.67 & 0.40 & 0.04 & 0.04 & $(0.02)$ & 0.18 \\
\hline Mimosa pudica & 0.01 & 0.02 & 0.88 & 0.21 & 0.12 & 0.12 & -1 & 0.12 \\
\hline Digitaria sanguinalis & 0.01 & 0.01 & 0.56 & 0.13 & 0.02 & 0.02 & & 0.06 \\
\hline Erigeron bonariensis & 0.02 & 0.03 & 1.67 & 0.40 & 0.16 & 0.16 & $\overline{(0.01)}$ & 0.20 \\
\hline Piper aducam & 0.02 & 0.03 & 1.39 & 0.33 & 0.09 & 0.08 & & 0.15 \\
\hline Scleria secans & 0.01 & 0.01 & 0.56 & 0.13 & 0.05 & 0.05 & & 0.07 \\
\hline Solanum grandiflorum & 0.01 & 0.01 & 0.56 & 0.13 & 0.05 & 0.05 & & 0.06 \\
\hline Cecropia so & 0.00 & 0.00 & 0.56 & 0.13 & 0.04 & 0.04 & & 0.06 \\
\hline Crotum lobatus & 0.04 & 0.06 & 1.30 & 0.31 & 0.04 & 0.04 & $(0.01)$ & 0.14 \\
\hline Phyllanthus niruri & 0.01 & 0.01 & 1.11 & 0.27 & 0.01 & 0.01 & & 0.10 \\
\hline Ageratum convzoides & 0.01 & 0.01 & 0.56 & 0.13 & 0.06 & 0.06 & & 0.07 \\
\hline Cuperus sp & 0.02 & 0.04 & 0.93 & 0.22 & 0.01 & 0.01 & $(0.01)$ & 0.09 \\
\hline Clidemia hirta & 0.00 & 0.00 & 0.56 & $\overline{0.13}$ & 0.00 & 0.00 & & 0.05 \\
\hline Sida glaziovii & 0.00 & 0.00 & 0.56 & $\overline{0.13}$ & 0.02 & 0.02 & & \\
\hline Asteraceae (sp 4) & 0.00 & 0.00 & 0.56 & 0.13 & 0.02 & 0.02 & & 0.05 \\
\hline Dalbergia so & 0.01 & 0.01 & 0.56 & 0.13 & 0.01 & 0.01 & & 0.05 \\
\hline Vismia sp & 0.01 & 0.01 & 0.56 & 0.13 & 0.01 & 0.01 & & \\
\hline O. angustifolius & 0.00 & 0.00 & 0.56 & 0.13 & 0.01 & 0.01 & & \\
\hline Mirtaceae (sp 3) & 0.00 & 0.00 & 0.56 & 0.13 & 0.04 & 0.04 & & 0.06 \\
\hline Fabaceae (SD 5) & 0.00 & 0.00 & 0.56 & 0.13 & 0.01 & 0.01 & & \\
\hline
\end{tabular}

Das 63 espécies, a maior importância coube a $F$. annua (16,31), seguido de P. multicaule (10,98), B. humidicola (10,39) e $S$. juripeba $(10,26)$. As 2 primeiras são monocotiledôneas de ciclo anual. A terceira espécie é uma gramínea perene, introduzida na Amazônia para formação das pastagens, portanto considerada remanescente das pastagens abandonadas. A quarta espécie é uma invasora nativa de pastagens e de acordo com observações de campo, possui ciclo bianual e rebrota facilmente após as capinas tanto pelo caule como através das raízes. Formam pequenos agrupamentos de 4 indivíduos adultos por $\mathrm{m}^{2}$ e até 17 indivíduos jovens e/ou em fase de plântulas por $\mathrm{m}^{2}$.

Classificando as espécies de acordo com a suas densidades relativas, constatou-se que $F$. annua $(23,56 \%)$, P. multicaule $(22,74 \%$ ), Paspalum sp (11,64\%) são dominantes na área e ocupam juntas $57,94 \%$ da 
densidade total. Entretanto, apresentam juntas apenas $19,31 \%$ do total da fitomassa relativa.

Verifica-se também que entre as 10 espécies mais importantes em número de indivíduos por $\mathrm{m}^{2}, 70 \%$, estão representadas pelas familias Cyperaceae e Poaceae, com destaque para as espécies anuais que se reproduzem somente por sementes, $F$. annua e $P$. multicaule, que apresentam elevado número de indivíduos, caracterizando ruderalidade e, com isso grande distribuição geográfica. Nos $30 \%$ restantes, destacam-se, $S$. juripeba $(4,32 \%)$ e B. verticillata $(2,68 \%)$ com 2,97 e 1,84 ind. $/ \mathrm{m}^{2}$ respectivamente, sendo que ambas se reproduzem por semente e rebrotam com facilidade após as capina e rodagens.

Com base nos valores da freqüência relativa, constatou-se que, $F$. annua $(15,98 \%)$, S. juripeba $(9,85 \%)$, B. verticillata $(9,69 \%), B$. humidicola $(8,79 \%)$ e $P$. conjugatum $(8,79 \%)$ são as espécies mais comuns do estrato inferior dos sistemas agroflorestais e apresentaram juntas $51,17 \%$ de freqüência relativa. Estas mesmas espécies acumularam 58,53\% do total da fitomassa relativa, sendo que as espécies mais importantes para este parâmetro (FR), foram: $S$. jurepeba (16,60\%) seguido de $B$. humidicola $(16,37 \%)$ e $P$. conjugatum $(10,92 \%)$. As demais espécies apresentaram fitomassa relativa menor que $9.40 \%$. SOUSA, et al. (1994) no levantamento preliminar realizado nesta mesma área observaram que $B$. verticillata, $F$. annua, $S$. juripeba e $B$. humidicola destacavam-se como as espécies mais importantes e mais freqüentes nos sistemas.

Para avaliação do padrão de distribuição das espécies invasoras nos sistemas agroflorestais, foi utilizado o índice de McGinnies, tendo por base a razão entre os parâmetros, densidade relativa e freqüência absoluta, onde os índices maiores que " 2 " considera-se que a espécie possui distribuição agrupada, valores $\geq 0,5 \mathrm{e}<$ que 2 , distribuição aleatória e valores $<$ que 0,5 distribuição uniforme. Segundo estes critérios, dentre as 10 espécies mais importante 6 apresentaram distribuição agrupada: $F$. annua $(14,02), P$. multicaie (7,63), Paspalum sp (4.01), B. humidicola (2,60), P conjugatum 
$(2,84)$ e $S$. juripeba $(2,00)$. Com distribuição aleatória foram observadas 3 espécies, $B$. verticillata $(1,24)$, Digitaria $s p(1,12)$ e $H$. aturensis $(0,82)$ e uma com distribuição uniforme $S$. cayennensis $(0,23)$. A distribuição das espécies nos sistemas pode estar relacionado com a dispersão de sementes e o tipo de regeneração como foi observado para $S$. juripeba.

Analisando a densidade da comunidade a nível de grupo, verifica-se que as monocotiledôneas foram superiores em relação às dicotiledôneas em número de indivíduos por metro quadrado (Tabela 6). A densidade total das monocotiledôneas $\left(110,26\right.$ ind. $\left./ \mathrm{m}^{2}\right)$ é 8 vezes maior do que a densidade das dicotiledôneas (13.69 ind. $\left./ \mathrm{m}^{2}\right)$. Entretanto, com relação ao peso de matéria seca da fitomassa aérea, as monocotiledôneas $\left(60.56 \mathrm{~g} / \mathrm{m}^{2}\right)$ não chegaram a ser 2 vezes maiores do que as dicotiledôneas $\left(33.24 \mathrm{~g} / \mathrm{m}^{2}\right)$.

Tabela 6 - Densidade (Nr.ind.-número de indivíduos $/ \mathrm{m}^{2}$ ) e fitomassa (Peso em $\left.\mathrm{g} / \mathrm{m}^{2}\right)$ total das mono e dicotiledôneas ocorrente nos sistemas durante as 5 coletas.

\begin{tabular}{|c|c|c|c|c|c|c|}
\hline COLETAS & \multicolumn{2}{|c|}{ DICOTILEDÔNEAS } & \multicolumn{2}{|c|}{ MONOCOTILEDÔNEAS } & \multicolumn{2}{|c|}{ TOTAL } \\
\hline & $\mathrm{Nr}$.ind. $/ \mathrm{m}^{2}$ & $\operatorname{Peso}\left(\mathrm{g} / \mathrm{m}^{2}\right)$ & Nr.ind $/ \mathrm{m}^{2}$ & Peso(g/m²) & $\mathrm{Nr}$.ind $/ \mathrm{m}^{2}$ & $\overline{\operatorname{Peso}\left(\mathrm{g} / \mathrm{m}^{2}\right)}$ \\
\hline $1(\mathrm{mar} / 93)$ & $11.42 \mathrm{a}$ & $23.91 \mathrm{~A}$ & $31.06 \mathrm{c}$ & $13.91 \mathrm{~B}$ & $42.48 \quad \mathrm{c}$ & $37.38 \mathrm{C}$ \\
\hline 2(jun/93) & $13.89 \mathrm{a}$ & $37.39 \mathrm{~A}$ & $92.14 \mathrm{~b}$ & $35.03 \mathrm{~B}$ & $106.03 \mathrm{~b}$ & $72.42 \mathrm{~B}$ \\
\hline $3($ set/93) & $13.42 \mathrm{a}$ & $26.65 \mathrm{~A}$ & $80.11 \mathrm{~b}$ & $33.26 \mathrm{~B}$ & $93.53 \mathrm{BC}$ & $59.91 \mathrm{BC}$ \\
\hline $4(\mathrm{mar} / 94)$ & $18.81 \mathrm{a}$ & $30.68 \mathrm{~A}$ & $175.78 \mathrm{a}$ & $113.90 \mathrm{~A}$ & $194.59 a$ & $144.80 \mathrm{~A}$ \\
\hline $5(\operatorname{set} / 94)$ & $10.92 \mathrm{a}$ & $47.55 \mathrm{~A}$ & $172.19 \mathrm{a}$ & $107.24 \mathrm{~A}$ & $183.11 \mathrm{a}$ & $154.79 \mathrm{~A}$ \\
\hline MÉDIA & 13.69 & 33.24 & 110.26 & 60.56 & 123.95 & 93.80 \\
\hline $\mathrm{CV}$ & 17,25 & 21,28 & 10,83 & 17,45 & 19,93 & 8,33 \\
\hline
\end{tabular}

Médias não transformadas. Médias nas colunas seguidas pelas mesmas letras não diferem significativamente entre si ao nivel de $\mathbf{5 \%}$ de probabilidade pelo teste de Tukey.

De acordo com a densidade das monocotiledôneas e com base na densidade ao nível de espécie, sugere-se que o maior número de indivíduos encontrado para as monocotiledôneas é devido à grande ocortência dos capins anuais, $F$. annua e $P$. multicaule, que possuem um ciclo de vida curto e produzem grande quantidade de sementes prontamente germináveis logo que chegam ao solo. Assim como pelas formas vegetativas (estolões e 
rizomas) das gramíneas, $B$. humidicola, $P$. conjugatum e H.aturensis, estabelecidas na área.

Apesar das monocotiledôneas apresentarem uma maior densidade de, e maior proporção de biomassa verde na cobertura do solo, observa-se que, a nível de peso da matéria seca da fitomassa aérea, foram as dicotiledôneas que apresentaram os indivíduos com maior acúmulo de reserva (fitomassa aérea). Em média cada dicotiledônea pesava $2,42 \mathrm{~g} / \mathrm{m}^{2}$, enquanto que uma monocotiledônea pesava somente $0,55 \mathrm{~g} / \mathrm{m}^{2}$. Devido ao fato das dicotiledôneas geralmente apresentarem-se mais fibrosas e possuírem caule de sustentação semi lenhoso ( mesmo àquelas consideradas herbáceas como as do gênero: Borreria, Sida e Solanum) estas devem acumular maior quantidade de reservas de produção dos agroecossistemas.

Observando a Figura 8, verifica-se que, as dicotiledôneas apresentaram maiores concentrações em todos os nutrientes $(\mathrm{N}, \mathrm{P}, \mathrm{K}, \mathrm{Ca}$ e $\mathrm{Mg}$ ) analisados, com destaque para $\mathrm{Ca}, \mathrm{N}$ e $\mathrm{P}$ que apresentaram uma diferença no acúmulo destes nutrientes na ordem de 77,52 e $47 \%$ respectivamente, em relação aos acumulados pelas monocotiledôneas.

\section{Concentrặăo (\%)}

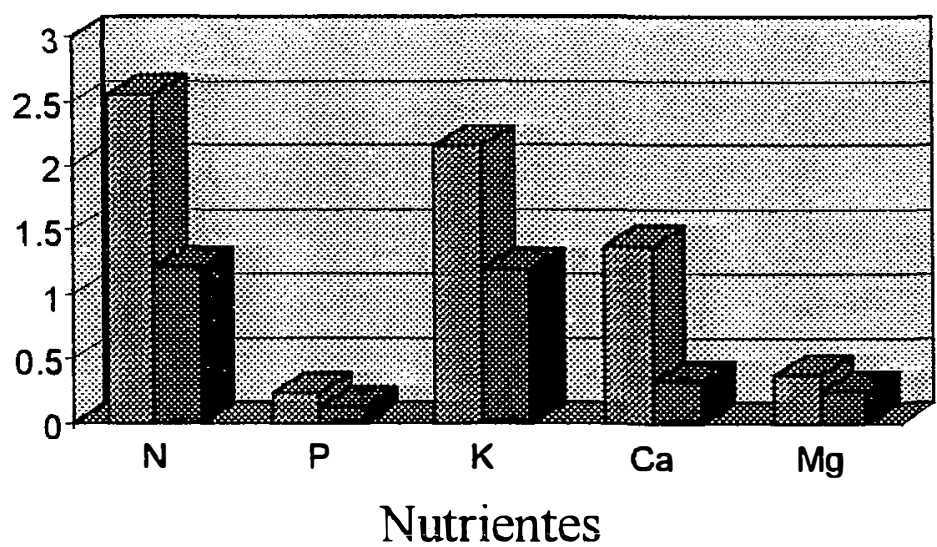

(rientes

Figura 8 - Porcentagem de nutrientes na fitomassa das mono e dicotiledôneas invasoras, ocorrente nos sistemas agroflorestais. 
Considerando-se que os dois grupos de plantas encontravam-se vegetando nas mesmas condições de fertilidade do solo (Tabela 3) pode-se constatar que as dicotiledôneas são mais eficientes do que as monocotiledôneas na absorção de nutrientes. Esse fato torna as dicotiledôneas plantas desejáveis em cobertura morta e áreas de pousio, pois armazenam nutrientes, evitando suas perdas para fora do sistema. Por outro lado, quando encontram-se vegetando em maior densidade nos sistemas podem se tornar mais competitivas com as plantas cultivadas, devendo portanto ser controladas.

\subsubsection{Regeneração e estágio de crescimento 3.1.1.3.1. Regeneração}

A vegetação emergente no extrato inferior dos sistemas podem ser originadas através de sementes (banco de sementes do solo, ou de chuva de sementes, ou chegadas de sementes), e de rebrotamento de plantas que foram cortadas pela ação das capinas ou de outros implementos agricolas.

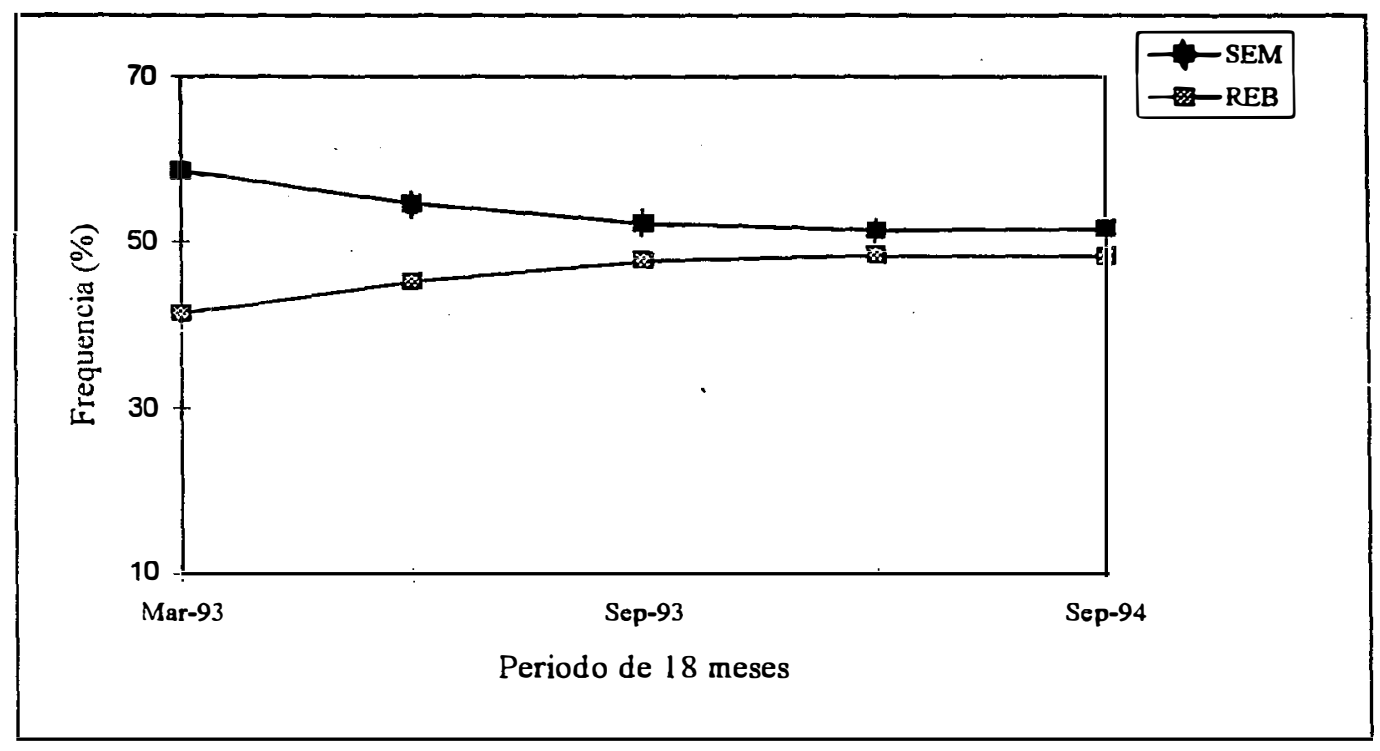

Figura 9 - Freqüência (\%) da ocorrência de plantas invasoras originadas de sementes e rebrotamento ao longo de 18 meses.

De acordo com a Figura 9, observa-se que, ao longo do período de coletas, a freqüência das emergências por sementes sofreram uma pequena redução, de 59 para $52 \%$ do total das ocorrências, e a freqüência de plantas originadas por rebrotamento passaram de 41 para $48 \%$, sugerindo o 
esgotamento do banco de sementes do solo, seguido de uma estabilização na reposição do estoque de sementes produzidas pelas plantas adultas que rebrotaram.

Ao nível dos grupos (mono e dicotiledôneas) e ao longo do período de coletas, constatou-se que o número de plantas dicotiledôneas proveniente da germinação de sementes foi proporcionalmente semelhante (Tabela 7), enquanto que número de plantas originadas por rebroto (regeneração por propagação vegetativa), foram diferentes estatisticamente ao nível de $5 \%$ de probabilidade. Durante a $4^{\mathrm{a}}$ coleta (mar/94), constatou-se um aumento da freqüência dos rebrotos das dicotiledôneas, porém na $5^{\mathrm{a}}$ coleta (set/94), esta ocorrência diminuiu para os níveis da $1^{\mathrm{a}}$ coleta (mar/93).

Tabela 7 - Tipo de regeneração das mono e dicotiledôneas por $\mathrm{m}^{2}$ por período de coleta $(1,2,3,4,5)$.

\begin{tabular}{|l|l|l|l|l|l|l|}
\hline \multirow{2}{*}{ COLETAS } & \multicolumn{2}{|c|}{ DICOTILEDONEAS } & MONOCOTILEDONEAS & \multicolumn{2}{c|}{ TOTAL } \\
\cline { 2 - 7 } & $\begin{array}{c}\text { SEMENTE } \\
\left(\mathrm{m}^{2}\right)\end{array}$ & $\begin{array}{c}\text { REBROTO } \\
\left(\mathrm{m}^{2}\right)\end{array}$ & $\begin{array}{c}\text { SEMENTE } \\
\left(\mathrm{m}^{2}\right)\end{array}$ & $\begin{array}{c}\text { REBROTO } \\
\left(\mathrm{m}^{2}\right)\end{array}$ & $\begin{array}{c}\text { SEMENTE } \\
\left(\mathrm{m}^{2}\right)\end{array}$ & $\begin{array}{c}\text { REBROTO } \\
\left(\mathbf{m}^{2}\right)\end{array}$ \\
\hline l(mar/93) & $11,25 \mathrm{~A}$ & $9,30 \mathrm{~b}$ & $56,83 \mathrm{~B}$ & $5,10 \mathrm{c}$ & $68,07 \mathrm{C}$ & $14,40 \mathrm{c}$ \\
$2(\mathrm{jun} / 93)$ & $17,81 \mathrm{~A}$ & $14,59 \mathrm{ab}$ & $98,49 \mathrm{~B}$ & $38,09 \mathrm{~b}$ & $116,31 \mathrm{~B}$ & $52,68 \mathrm{~b}$ \\
$3(\mathrm{set} / 93)$ & $10,91 \mathrm{~A}$ & $16,28 \mathrm{ab}$ & $66,02 \mathrm{~B}$ & $35,16 \mathrm{~b}$ & $76,94 \mathrm{BC}$ & $51,44 \mathrm{~b}$ \\
$4(\mathrm{mar} / 94)$ & $14,59 \mathrm{~A}$ & $22,65 \mathrm{a}$ & $237,46 \mathrm{~A}$ & $157,59 \mathrm{a}$ & $252,05 \mathrm{~A}$ & $180,24 \mathrm{a}$ \\
$5(\mathrm{set} / 94)$ & $16,78 \mathrm{~A}$ & $9,39 \mathrm{~b}$ & $214,86 \mathrm{~A}$ & $151,41 \mathrm{a}$ & $231,64 \mathrm{~A}$ & $160,80 \mathrm{a}$ \\
\hline Total & 71,34 & 72,21 & 673,67 & 387,36 & 745,00 & 459,57 \\
Media & 14,27 & 14,44 & 134,73 & 77,47 & 149,00 & 91,91 \\
CV & 25,73 & 23,52 & 11,61 & 18,38 & 9,27 & 12,61 \\
\hline
\end{tabular}

médias não transformadas. Médias nas colunas seguidas pelas mesmas letras não diferem significativamente ao nível de $5 \%$ de probabilidade pelo Teste de Tukey.

Para as monocotiledôneas, as freqüências de plantas originadas tanto de sementes como de rebrotos foram significativamente diferentes ao nível de $5 \%$ de probabilidade ao longo dos períodos observados. Sendo que o número de plantas originadas de sementes em março/94 e setembro/94 foi superior ao das coletas de março/93, junho/93 e setembro/93 $\left(1^{\mathrm{a}}, 2^{\mathrm{a}}\right.$ e $3^{\mathrm{a}}$ coletas respectivamente). Resultados semelhantes foram encontrados para as emergências das monocotiledôneas originadas por rebroto em março/94 e setembro/94. 
Entretanto, o número de indivíduos provenientes de rebroto em mar/93 ( $1^{\text {a }}$ coleta) foi inferior as demais coletas. Com referência à propagação sexuada e assexuada, PITELLI (1985), discute que o potencial de propágulos deste ano agrícola, irá se juntar ao potencial remanescente no solo, que enriquecido pelos propágulos importados e os produzidos em ciclos de entre safra, constituirão o potencial de colonização do próximo ano. Portanto justifica-se o aumento de plantas originadas de rebroto para monocotiledôneas.

As gramíneas com capacidade de se estabelecerem por rizomas, estolões, tubérculos e bulbos, são mais difíceis de serem controladas; tanto mecanicamente através de capinas, aração e gradagem, como por produtos químicos; devido ao fato de cada pedaço vegetativo com gemas dormentes seccionado pela ação dos implementos agrícolas possuir capacidade de gerar um novo indivíduo, ou de dificultarem a ação dos herbicidas (KLINGMAN \& ASHTON, 1989). Quanto maior a quantidade de reservas vegetativa maior capacidade de persistência destas plantas.

As plantas originadas de sementes não sofreram influência significativa dos SAFs (Tabela 8), enquanto que, as provenientes de rebrotação apresentaram diferença estatisticamente significativa ao nível de $5 \%$ de probabilidade pelo teste de Tukey. O SAF 4 foi diferente dos demais, apresentando o menor número de indivíduos emergentes por rebrotamento do que os demais, prevalecendo as emergências por sementes. Isto pode ser explicado pelo fato desta parcela ter sido gradeada no início do plantio das culturas anuais. Esta prática pode ter reduzido através do corte e enterrio mais profundo, os restos vegetativos remanescentes das plantas invasoras e com capacidade de formar um novo indivíduo, principalmente $B$. verticillata e $S$. jurpeba, cujas espécies, rebotaram com facilidade e vigorosamente após as primeiras capinas nos sistemas que não foram gradeados (SAF1, SAF2 e SAF3). Entretanto B. humidicola que multiplica-se também assexuadamente, pode ter sido favorecido por esta prática (Figura 15).

Constatou-se ao nível das espécies que, $B$. verticillaia ocorreu durante todo período em média $36 \%$ através de rebrotamento e para 
S. juripeba as maiores ocorrências foram originada de rebrotamento $(95 \%)$, sendo que na última coleta set/94 foi verificado uma pequena redução, nas emergências originadas de rebrotamento (90\%).

Tabela 8 - Regeneração das mono e dicotiledônias por $\mathrm{m}^{2}$ por parcela (SAF1, SAF2, SAF3, SAF4).

\begin{tabular}{|l|c|c|c|c|c|c|}
\hline TRAT & $\begin{array}{c}\text { DICOTILEONEAS } \\
\text { SEMENTE } \\
(\mathbf{m} 2)\end{array}$ & $\begin{array}{c}\text { MEBROTOS } \\
(\mathbf{m} 2)\end{array}$ & $\begin{array}{c}\text { MEMENTEC } \\
(\mathbf{m} 2)\end{array}$ & $\begin{array}{c}\text { REBROTOS } \\
(\mathbf{m} 2)\end{array}$ & $\begin{array}{c}\text { SEMENTES } \\
(\mathbf{m} 2)\end{array}$ & $\begin{array}{c}\text { REBROTOS } \\
(\mathbf{m} 2)\end{array}$ \\
\hline SAF1 & $20.49 \mathrm{~A}$ & $32.14 \mathrm{a}$ & $138.38 \mathrm{~A}$ & $40.45 \mathrm{a}$ & $158.87 \mathrm{~A}$ & $72.58 \mathrm{a}$ \\
SAF2 & $8.41 \mathrm{~A}$ & $19.30 \mathrm{ab}$ & $219.20 \mathrm{~A}$ & $70.81 \mathrm{a}$ & $227.62 \mathrm{~A}$ & $90.11 \mathrm{a}$ \\
SAF3 & $9.78 \mathrm{~A}$ & $18.73 \mathrm{~b}$ & $90.92 \mathrm{~A}$ & $33.45 \mathrm{a}$ & $100.70 \mathrm{~A}$ & $52.18 \mathrm{ab}$ \\
SAF4 & $22.87 \mathrm{~A}$ & $2.97 \mathrm{c}$ & $60.34 \mathrm{~A}$ & $39.25 \mathrm{a}$ & $83.21 \mathrm{~A}$ & $42.23 \mathrm{~b}$ \\
\hline TOT & 61.56 & 73.14 & 508.85 & 183.96 & 570.40 & 257.09 \\
MED & 15.39 & 18.28 & 127.21 & 45.99 & 11.50 & 2.87 \\
\hline CV & 25.73 & 23.53 & 11.61 & 18.38 & 9.27 & 12.61 \\
\hline
\end{tabular}

médias transformadas em log (n), médias nas colunas seguidas pelas mesmas letras não diferem significativamente ao nível de $5 \%$ de probabilidade pelo Teste de Tukey.

\subsection{Estágios de crescimento}

As dicotiledôneas apresentaram uma maior porcentagem de indivíduos jovens (53\%), seguidos de $31 \%$ de indivíduos adultos e $16 \%$ de plântulas. (Tabela 7), ao contrário das monocotiledôneas, cujo perfil no momento da coleta foi de $52 \%$ de indivíduos adultos, $38 \%$ jovens e $10 \%$ plântulas.

A maior ocorrência de plantas monocotiledôneas adultas deve-se a $F$. annua e $P$. multicaule, que são capins considerados anuais, produzem bastante sementes e alta densidade de plantas, juntas apresentam $46,30 \%$ da densidade relativa total e $20,27 \%$ da freqüência relativa total. 


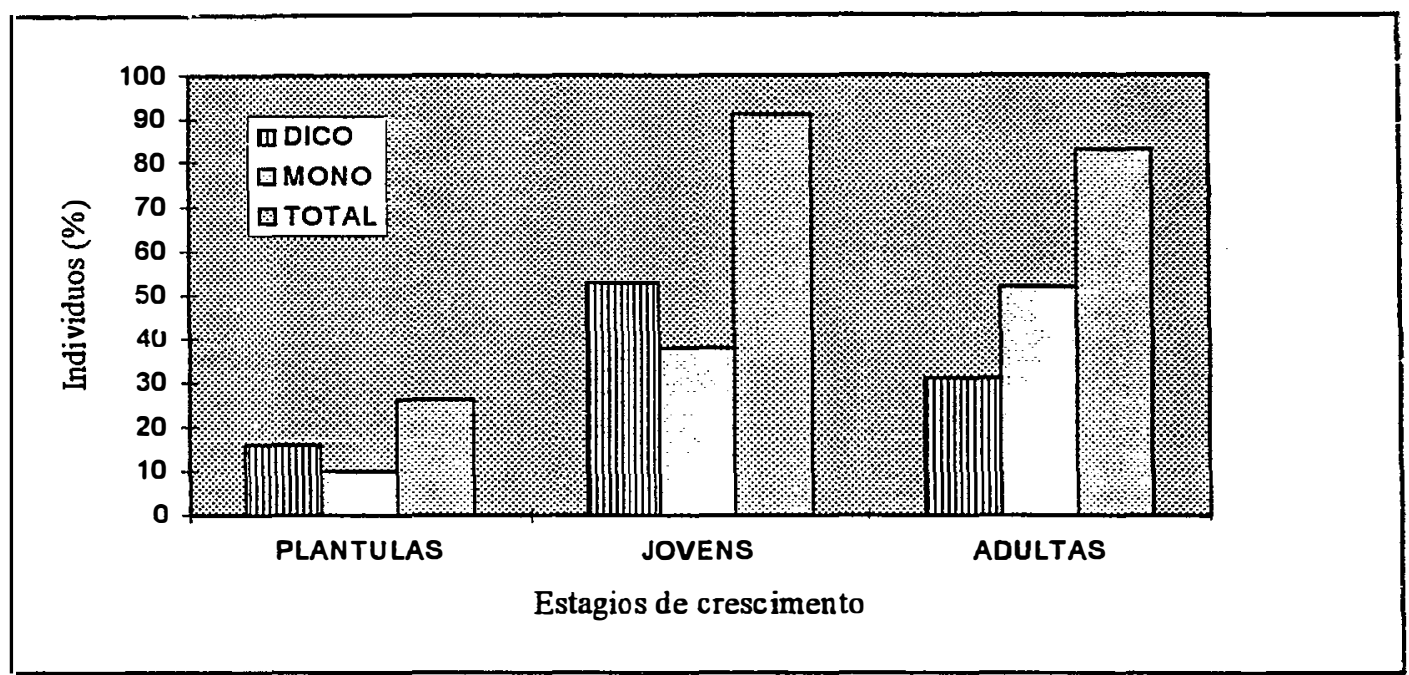

Figura 10 - Distribuição dos indivíduos (\%) em 3 estágios de desenvolvimento (plântulas, jovens e adultas)

As demais monocotiledôneas com capacidade de reprodução vegetativa, depois de estabelecidas, são persistente e dominam as áreas cultivadas através da estratégia da propagação vegetativa, deixando talvez, as sementes produzidas, armazenadas no banco de semente do solo para germinarem em outras condições.

Portanto, de acordo com os parâmetros avaliados, a comunidade de plantas secundárias que invadem os sistemas agroflorestais estudados é formada principalmente pelas monocotiledôneas que apresentaram mais de $50 \%$ das plantas em fase de floração e frutificação (adulta). Predominam em densidade com $88,95 \%$ dos indivíduos por metro quadrado e $64,56 \%$ (da fitomassa aérea) na cobertura da área. As dicotiledôneas ocupam o segundo plano com menor densidade, maior número espécies $(60 \%)$ e indivíduos relativamente mais pesados $\left(2,42 \mathrm{~g} / \mathrm{m}^{2}\right)$ do que das monocotiledôneas $\left(0,55 \mathrm{~g} / \mathrm{m}^{2}\right)$, com destaque para as espécies nativas, gênero Solanum e Borreria, assim como a chegada das, espécimes cosmopolitas, familia Asteraceae e Euphorbiaceae que gradativamente vão se estabelecendo nos sistemas a medida que se intensifica o uso solo. 


\subsection{Variação da Comunidade de Plantas Invasoras em 4 Sistemas Agroflorestais}

\subsubsection{Efeito dos sistemas agroflorestais na composição florística}

\subsubsection{Distribuição das Famílias, Gêneros e Espécies}

Foram registradas, 18 famílias, 63 espécies e 40 gêneros botânicos distribuídos nos diferentes tipos de SAFs (Tabela 9). O SAF3 foi o sistema que contribuiu com o menor número de gêneros e espécies e o SAF2 com o menor número de famílias. Nos demais tratamentos a presença das comunidades foi semelhante, sendo o SAF1 o sistema que contribuiu para maior riqueza de espécies e famílias. Este sistema apresentou $73 \%$ do total das espécies registradas e $77 \%$ do total das famílias presentes nos sistemas.

Tabela 9 - Número de famílias, gêneros, espécies, suas restrições nos quatro sistemas (SAF1, SAF2, SAF3 e SAF4) e porcentagem em relação ao total observado

\begin{tabular}{|l|c|c|c|c|c|}
\hline & SAF1 & SAF2 & SAF3 & SAF4 & TOTAL \\
\hline $\mathrm{N}^{0}$ de famílias & $14(77 \%)$ & $10(55 \%)$ & $13(72 \%)$ & $13(72 \%)$ & 18 \\
\hline $\mathrm{N}^{0}$ de gêneros & $27(66 \%)$ & $28(70 \%)$ & $19(46 \%)$ & $28(70 \%)$ & 40 \\
\hline $\mathrm{N}^{0}$ de espécies & $46(73 \%)$ & $39(61 \%)$ & $29(46 \%)$ & $45(71 \%)$ & 63 \\
\hline $\mathrm{N}^{0}$ de sp. restritas & 4 & 2 & 3 & 4 & - \\
\hline
\end{tabular}

No SAF2 ocorreram 2 espécies restritas a este sistema que foram: Vismia cayennesis e Acanthospermum australe. A primeira espécie é comum nas áreas de pastagens abandonadas. UHL et al. (1988), registraram que os gêneros Vismia e Solanum ocorrem com freqüência na vegetação secundária de pastagens degradadas e abandonadas na Amazônia. Porém, a segunda é ưma espécie cosmopolita ocorrente nos agroecossistemas e deverá aparecer também, nos demais sistemas com o passar do tempo. As espécies restritas do SAF3 foram das famílias Cecropiaceae (Cecropia sp), Melastomataceae (Clidemia hirta) e Bignoniaceae (Tabebuia sp.). Apesar das duas primeiras ocorrem uma única vez durante todos os períodos de coletas, chamam atenção por se tratarem de 
pioneiras de vegetação secundária em pastagens abandonadas e estarem presentes num sistema menos perturbado (agrosilvipastoril de baixos insumos). No SAF1 as espécies restritas foram uma Mirtaceae (espécie não identificada), uma Leguminoseae (espécie não identificada), Digitaria sanguinallis (Poaceae) e Sida glaziovii (Malvaceae). As duas primeiras originaram-se de rebrotos de árvores remanescentes da vegetação secundária das pastagens degradadas e, as 2 últimas, são invasoras tradicionais dos agroecossistemas. Essas espécies, entretanto, são de pouca significância, pois todas as 4 ocorreram somente uma vez durante todas as coletas.

As espécies restritas para o SAF4 foram: Commelina benghalensis, Physalis pubescens, Phyllanthus niruri e uma Asteraceae (espécie não identificada). As duas primeiras espécies, ocorreram durante os 5 periodos de coleta (Tabela 2-apêndice), podendo ser consideradas como exclusivas do SAF4 (sistema agrosilvipastoril - altos insumos) e devem estar ocorrendo neste sistema devido à melhoria das condições físicas e químicas do solo, proporcionados pela gradagem, calagem e aplicação de fertilizantes químicos. As duas últimas espécies apareceram no sistema uma única vez, apesar da terceira trata-se de uma invasora comum de acordo com (LORENZI, 1994).

Observou-se também que das 63 espécies, 15 são comuns a todos os SAFs (Tabela 1-apêndice), com destaque para $F$. annua, S. jurepeba, $B$. humidicola, $B$. verticillata, $P$. conjugatum, $S$. cavennensis e $S$. rugosum, cujas espécies, estão entre as 10 mais importantes pelo I.V.I (Tabela 5).

\subsubsection{Diversidade das espécies invasoras nos sistemas agroflorestais}

Com base no Índice de Diversidade de Shannon Weaver (Tabela i 1) pode-se observar que a diversidade das espécies invasoras nos SAFs é maior do que nas pastagens e que o SAF1, SAF2 e SAF3 foram os sistemas que apresentaram maior diversidade, ao longo do período, com pequena variação para menor diversidade no SAF2 e SAF3, em junho/93 ( $2^{\mathrm{a}}$ coleta). 
Tabela 11 - Índice de diversidade de Shannon Weaver (H') e equabilidade (J) para as comunidades de plantas invasoras, ao longo de 18 meses em sistemas agroflorestais implantados em áreas de pastagens degradadas.

\begin{tabular}{cccccc}
\hline PERÍODO & ÁREA & ESPECIES & INDIVIDUOS & H & J \\
\hline 1 & SAF1 & 16 & 386 & 1.6476 & 0.5948 \\
2 & & 19 & 809 & 1.6967 & 0.5762 \\
3 & & 21 & 688 & 2.1141 & 0.6944 \\
4 & & 28 & 1752 & 2.1271 & 0.6382 \\
5 & & 24 & 1890 & 2.3143 & 0.7282 \\
MEDIA & & & & 1.9799 & $\mathbf{0 . 6 4 6 3}$ \\
1 & SAF2 & 16 & 471 & 1.7246 & 0.6220 \\
2 & & 21 & 1638 & 1.2770 & 0.4194 \\
3 & & 24 & 1465 & 1.3428 & 0.4225 \\
4 & & 28 & 2720 & 1.9167 & 0.5752 \\
5 & & 27 & 3061 & 2.1949 & 0.6659 \\
MEDIA & & & & 1.6912 & $\mathbf{0 . 5 4 1 0}$ \\
1 & SAF3 & 13 & 484 & 1.4316 & 0.5581 \\
2 & & 18 & 1082 & 1.6059 & 0.5556 \\
3 & & 16 & 932 & 1.5872 & 0.5724 \\
4 & & 21 & 1312 & 1.9068 & 0.6266 \\
5 & & 21 & 765 & 2.0491 & 0.6730 \\
MEDIA & & & & 1.7161 & $\mathbf{0 . 5 9 7 1}$ \\
1 & SAF4 & 12 & 188 & 1.7824 & 0.6730 \\
2 & & 27 & 328 & 2.2991 & 0.6975 \\
3 & & 14 & 282 & 1.6329 & 0.6187 \\
4 & & 29 & 1221 & 2.1933 & 0.6513 \\
5 & & 32 & 876 & 1.9934 & 05751 \\
MEDIA & & & & 1.9802 & $\mathbf{0 . 6 4 3 1}$ \\
- & PA* & 18 & 1514 & $\mathbf{0 . 7 0 7 7}$ & $\mathbf{0 . 2 4 4 8}$ \\
\hline
\end{tabular}

(*) Referente a uma coleta no mês de dezembro/93.

No SAF4, a diversidade sofreu alteração durante todo o período de observação, o que já era esperado devido ao nível de perturbação a que foi submetido este sistema. A alteração na diversidade pode estar relacionada com o histórico de manejo do solo e culturas. A comunidade de plantas invasoras do SAF4 sofreu a influência, do manejo do solo (gradagem, calagem e adubação), cultura do milho, da cultura do feijão, da cultura da mandioca e do plantio e estabelecimento do Desmodium. Diferentes autores como ROBERTS (1963); CHANCELLOR (1985) e DERKSEN et al. (1993), têm sugerido e demonstrado que as práticas culturais e intensificação dos cultivos provocam desequilíbrio nas 
populações de invasoras, com aparecimento e desaparecimento de espécies, alterando a diversidade da comunidade de plantas invasoras nos agroecossistemas, fato esse que pode ter ocorrido no SAF4.

O aumento da diversidade de plantas invasoras em cultivo de milho em áreas de pastagens, também foi observado por GARCIA (1988). A autora explica que isto ocorre devido ao aumento da riqueza das espécies invasoras, acompanhada da redução das espécies dominantes das pastagens. Entretanto, esta constatação não é diretamente explicada pelo modelo de MILLER (1982), segundo o qual, áreas que sofrem perturbações intensas e freqüentes, tendem a apresentar menor diversidade, principalmente com monocultivo. Porém, segundo a mesma autora, este período pode representar uma fase transitória ajustando-se ao modelo, após alguns anos.

$O$ índice de equabilidade $(\mathrm{J})$, refere-se a razão entre o índice de diversidade ( $\left.\mathrm{H}^{\prime}\right)$ e número total de espécies de uma comunidade. No SAF1 e SAF4 este índice foi de 0,64 , indicando que esses sistemas apresentaram maior número de espécies, quando comparados com SAF2 e SAF3, 0,54 e 0,59 respectivamente.

\subsubsection{3. Índice de Similaridade de Jaccard - ISJ}

A partir do Índice de Similaridade de Jaccard (Tabela 10), verifica-se a seguinte ordem de similaridade entre as áreas (SAF1 $x$ SAF2) > $(\mathrm{SAF} 1 \times \mathrm{SAF} 4)>(\mathrm{SAF} 1 \times \mathrm{SAF} 3)>(\mathrm{SAF} 1 \times \mathrm{PA})$. Em seguida $(\mathrm{SAF} 2 \times \mathrm{SAF} 4)$ $>(\mathrm{SAF} 2 \times \mathrm{SAF} 3)>(\mathrm{SAF} 2 \times \mathrm{PA})$ e $(\mathrm{SAF} 3 \times \mathrm{SAF} 4)>(\mathrm{SAF} 3 \times \mathrm{PA})$. Este índice é baseado no número de espécies comuns nas áreas avaliadas $\mathrm{e}$ indicou que intensificação do uso do solo das pastagens degradadas alterou a comunidade de plantas invasoras possibilitando a formação de novas comunidades de acordo com cada sistema.

Observou-se que as comunidades de plantas invasoras que ocorreram nos sistemas foram diferentes em relação a comunidade das pastagens em 62 a $74 \%$ e, de maneira geral as comunidades de plantas invasoras que ocorreram no estrato inferior dos SAFs apresentaram uma composição florística 
semelhante em 50 a 63,46\%, com exceção de (SAF3 x SAF4), cuja similaridade foi de $40 \%$.

Tabela 10 - Índice de Similaridade de Jaccard (\%).

\begin{tabular}{|l|llll|}
\hline & SAF1 & SAF2 & SAF3 & SAF4 \\
\hline SAF2 & $\mathbf{6 3 , 4 6}$ & - & - & - \\
SAF3 & 50,00 & 51,11 & - & - \\
SAF4 & $\mathbf{5 9 , 6 5}$ & $\mathbf{5 5 , 6 6}$ & 39,62 & - \\
PA & 30,61 & 32,56 & 38,23 & 26,00 \\
\hline
\end{tabular}

\subsubsection{Efeito dos sistemas agroflorestais na densidade}

$\mathrm{O}$ número de indivíduos por metro quadrado, para os sistemas SAF1 (122,78 ind./m²), SAF2 (207,89 ind./m²), SAF3 $(100,78$ ind./m²) e SAF4 $\left(64,33\right.$ ind. $\left./ \mathrm{m}^{2}\right)$ não apresentou diferenças significativa ao nível de $5 \%$ de probabilidade, apesar das médias absolutas e não transformadas entre SAF2 e SAF4 apresentarem uma grande variação no número de indivíduos por metro quadrado.

Observa-se que existe uma predominância das monocotiledôneas sobre as dicotiledôneas em todos os tratamentos. Porém, o SAF2 (sistema agrosilvicultural) foi o sistema que proporcionou, em média, a maior ocorrência de monocotiledôneas (196 ind. $/ \mathrm{m}^{2}$ ) seguido do SAF1 (sistema agrosilvicultural) com 102,96 ind./m² (Figura 11). 


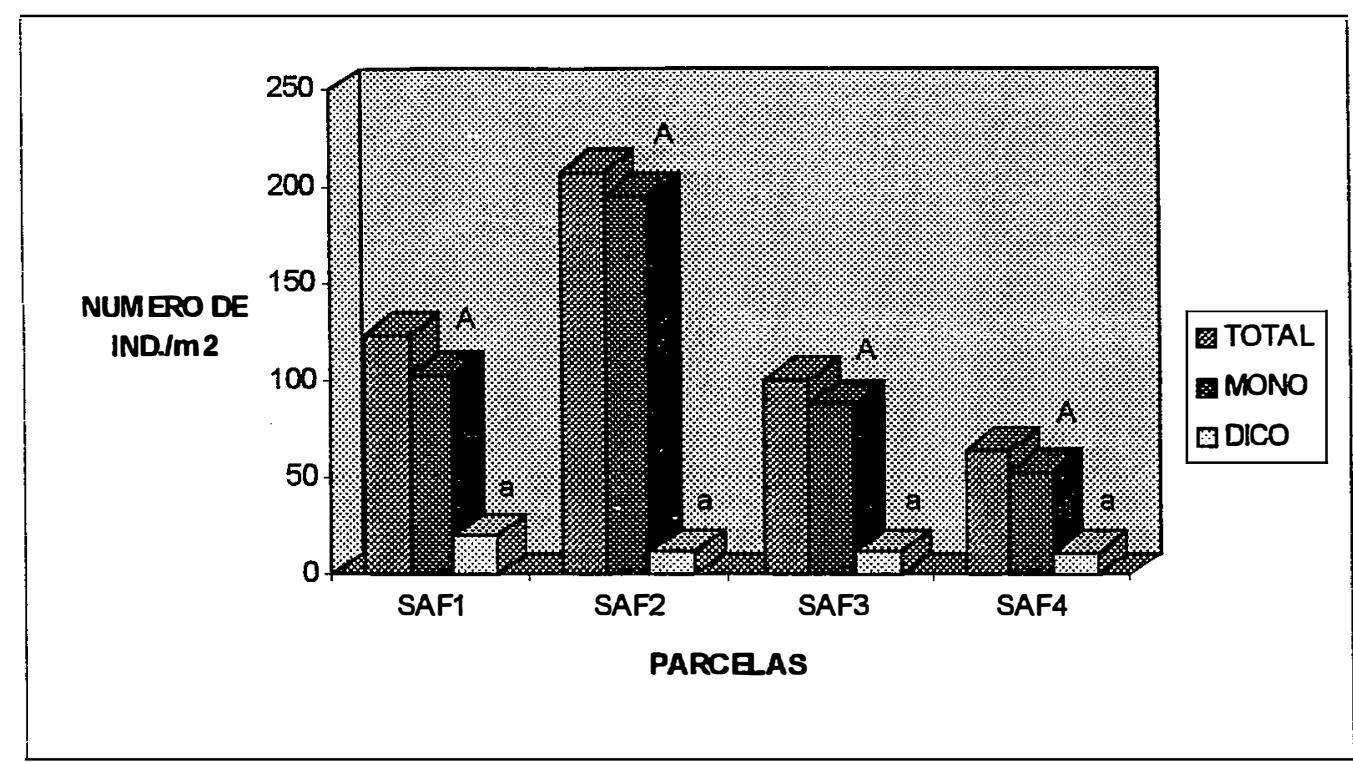

Figura 11 - Densidade (ind. $/ \mathrm{m}^{2}$ ) de mono e dicotiledôneas ocorrentes nas parcelas dos sistemas agroflorestais (SAF1, SAF2. SAF3 e SAF4). As médias seguidas da mesma letra não diferem entre si, ao nível de $5 \%$ de probabilidade pelo teste de Tukey.

Por outro lado, no SAF4 (sistema agrosilvipastoril - altos insumos) e SAF3 (sistema agrosilvipastoril - baixos insumos), as ocorrências foram menores, tanto para dicotiledôneas (SAF4 apresentou 10,93 e SAF3 12,40 ind. $/ \mathrm{m}^{2}$ ) como para monocotiledôneas (SAF4 apresentou 53,33 e SAF3 apresentou 88,38 ind. $\left./ \mathrm{m}^{2}\right)$.

Os efeito dos SAFs na densidade relativa nas 10 espécies mais importantes são apresentadas na Figura 12. Essas espécies representam mais de $90 \%$ da densidade relativa total, com exceção do SAF4, cujo percentual é de 89\%. As espécies $F$. annua e P. multicaule foram as de maior importância para este parâmetro. Estas espécies são consideradas gramíneas anuais, produzem grande quantidade de sementes e reproduzem-se apenas por semente.

No SAF1, as 10 espécies com maior número de indivíduos por $\mathrm{m}^{2}$, totalizam $92,19 \%$ da densidade relativa total, sendo que a $F$. annua sozinha apresentou uma densidade relativa de $38,64 \%\left(41\right.$ ind. $\left./ \mathrm{m}^{2}\right)$, seguido de $S$. juripeba, com $10,06 \%$, B. humidicola $9,35 \%$ e Paspalum sp 9,25\%. As demais espécies apresentaram uma densidade que variaram de 1,55 a $6,83 \%$. Constatouse também que no SAF1, $80 \%$ das 10 primeiras espécies são monocotiledôneas e 
dominam o estrato inferior deste sistema com $76,09 \%$ da densidade relativa total, indicando a existência de fatores ambientais ou biológicos que restringem o número de indivíduos das outras espécies no sistema. Durante as coletas observou-se, maior ocorrência de invasoras nas linhas do cupuaçu do que nas linhas da pupunha, sugerindo que o volumoso sistema radicular superficial da pupunheira esteja funcionando como uma barreira contra o estabelecimento das plantas invasoras.

No SAF2, as primeiras 10 espécies com maior densidade representam $92,89 \%$ da densidade relativa total. A. P. multicaule se destacou como a mais importante, $\left(44,02 \%\right.$ e 79 ind./ $\left./ \mathrm{m}^{2}\right)$, seguida pela $F$. annua $(14,82 \% \mathrm{e}$ 27 ind. $\left./ \mathrm{m}^{2}\right)$, Paspalum sp. $\left(9,21 \%\right.$ e 24 ind. $\left./ \mathrm{m}^{2}\right)$ e uma gramínea (espécie não identificada - capim sp2.) com $6,88 \%$ e 23 ind. $/ \mathrm{m}^{2}$. As demais espécies apresentaram densidades relativas que variaram de $1,37 \%$ a $5,51 \%$, com médias de 4 a $10 \mathrm{ind} . / \mathrm{m}^{2}$. Neste sistema (SAF2), verifica-se que as 4 espécies de maior importância, que representam $74,93 \%$ da densidade relativa total, foram aquelas que se reproduzem somente por sementes, com exceção de Paspalum sp. (capim semelhante a grama seda - Cynodon dactylon) que chega através de sementes e se estabelece por rizomas estolões. As demais espécies (S. juripeba, B. humidicola, P. conjugatum, Digitaria sp. e Commelina sp.), apresentam em comum a reprodução assexuada, exceto a $B$. plantaginea $\left(7^{\mathrm{a}}\right.$ colocada em densidade) que se reproduz por semente.

O SAF2 é um sistema de multiestratos, altamente adensado, composto seqüencialmente por várias espécies arbóreas e arbustiva e entrelinhas ocupadas pelos cultivos de ciclo curto, ao longo dos 18 meses (período observado). Portanto, foi o sistema que sofreu intensidade periódica de perturbação durante este período. A interferência de interações bióticas e abióticas, talvez possa explicar a presença de um conjunto muito pequeno de espécies, com capacidade de recolonizar este sistema através de sementes e a permanência estável de outras que apresentam reprodução vegetativa. 


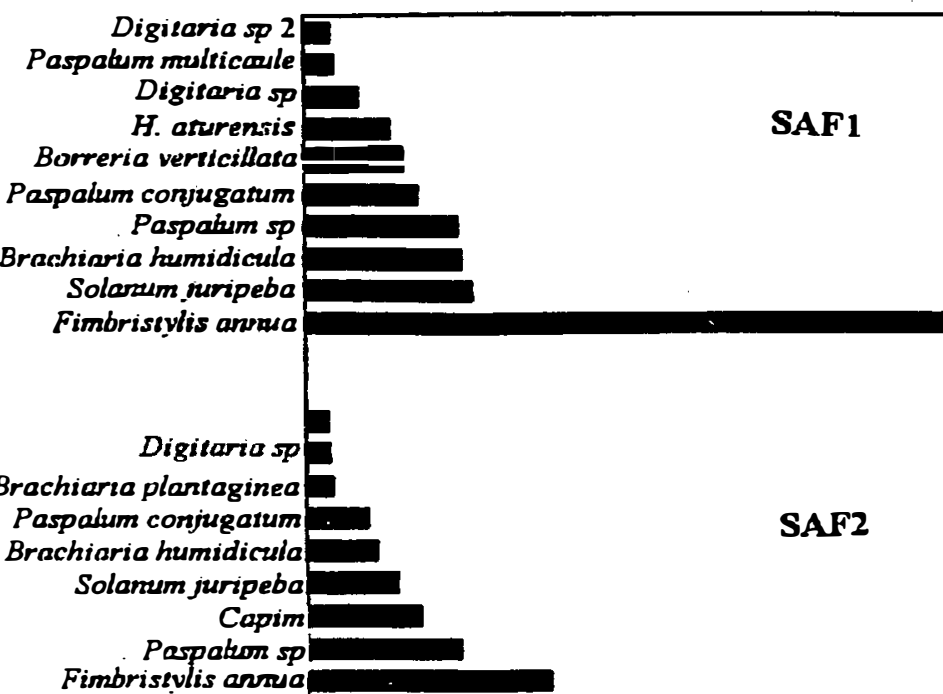

Paspalum meiticaule

Digitaria sp 2

Sida rhombifolia

Paspalum conjugatum

$H$. aswensis

Borreria verticillata

Brachiaria humidinula Solanssm juripeba

Paspalum sp

Fimbristylis annug

Pagalum mosticisulis

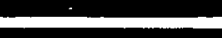

teragrostis sp

Slachiviuphera camnensis Calopogonio miconojdea

Paspalum sp

Phisalis angulara

Digiraria sp

Borrerta verticillato

Brachzaria dzumidicula

Paspaium conjugatum

Fimoristylis anurua
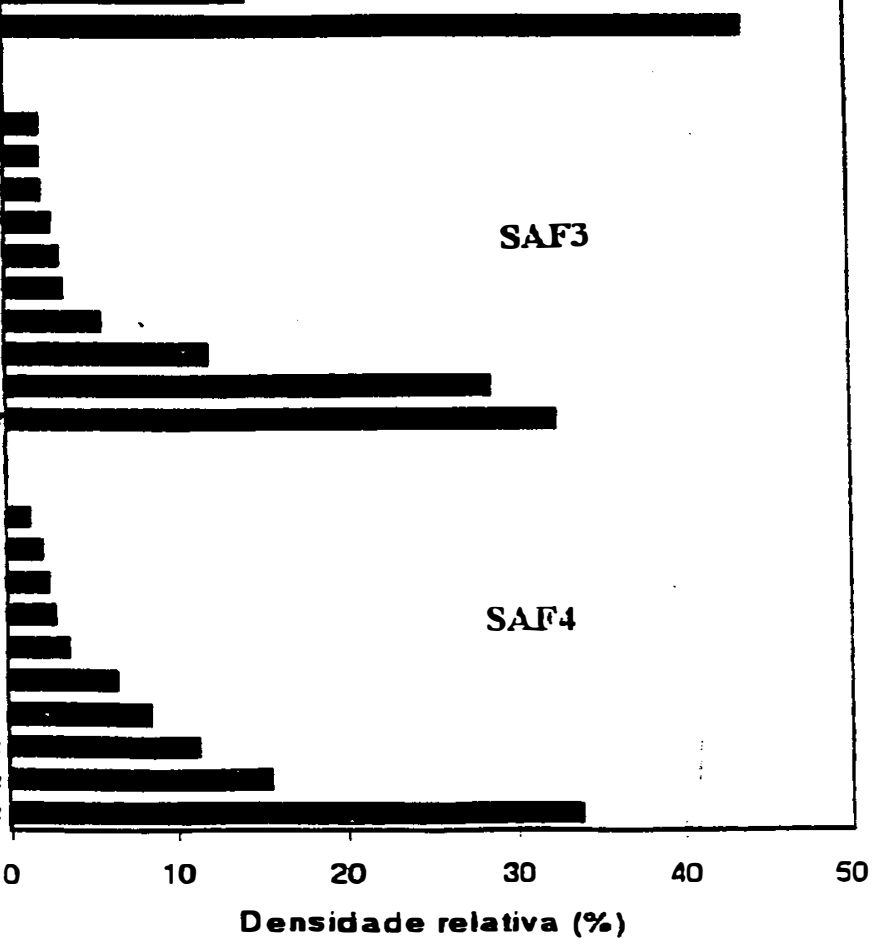

Figura 12 - Densidade relativa (\%) das espécies nos SAF1, SAF2, SAF3 e SAF4. 
No sistema agrosilvipastoril SAF3, as 10 espécies dominantes ocupam 95,39\% da densidade relativa total. As gramíneas (Poaceae e Cyperaceae) P. multicaule participam com $32,60 \%\left(30,38\right.$ ind.$\left./ \mathrm{m}^{2}\right)$ da densidade relativa total, seguido pela $F$. annua, com $28,75 \%\left(30,00\right.$ ind. $\left./ \mathrm{m}^{2}\right)$ e Paspalum sp $12,21 \%$ $\left(14,60\right.$ ind. $\left./ \mathrm{m}^{2}\right)$. Destaca-se também $S$. juripeba com 5 ind. $/ \mathrm{m}^{2}$ e densidade relativa de 5,60\%. As demais apresentaram uma densidade relativa que variou de 2,12 a $3,49 \%$ do total e, em média, 1,86 a 3,00 ind. $/ \mathrm{m}^{2}$.

As 10 principais espécies que ocorreram no SAF3 apresentam em comum a capacidade de colonizar área através de rebrotamento, com exceção de duas ( $F$. annua e $P$. multicaule), cujas espécies propagam-se somente por semente. Neste sistema (agrosilvipastoril - baixos insumos - SAF3) historicamente teve menor nível de perturbação, menor índice de diversidade e o número de espécies praticamente não variaram nas duas últimas coletas.

No SAF4 (sistema agrosilvipastoril - altos insumos) as 10 espécies de maior densidade, representaram $88,80 \%$ densidade relativa total. A espécie de maior importância foi a $F$. annua com 33,92\%, (18,91 ind. $\left./ \mathrm{m}^{2}\right)$, seguido de $P$. conjugatum com $15,75 \%$ (14.04 ind. $\left./ \mathrm{m}^{2}\right)$ e $B$. humidicola $11,32 \%$ $\left(4,33\right.$ ind. $\left./ \mathrm{m}^{2}\right)$ que, juntas, totalizam $61 \%$ do total. As demais espécies variaram entre 1,42 a $8,5 \%$ e apresentaram, em média 1,37 a 4,00 ind. $/ \mathrm{m}^{2}$. Neste sistema a presença de indivíduos proveniente de sementes foi maior do que os de rebrotação. Este fato pode estar relacionado com a gradagem da área para o plantio de milho, feijão e mandioca, que cortou e enterrou os restos vegetativos das plantas que poderiam regenerar-se através de rebrotos.

\subsubsection{Efeito dos Sistemas Agroflorestais na freqüência}

Classificando-se as espécies de acordo com suas freqüências relativas (Figura 13), verifica-se que $F$. annua, $S$. juripeba e $B$. verticillata se destacaram das demais espécies, ocupando as duas primeiras posições desse parâmetro. $F$. апnua foi destaque em todos os tratamentos, apresentando 19,17; 15,$70 ; 20,02$ e $19,39 \%$ da freqüência relativa total, nos SAF1, SAF2, SAF3 e SAF4, respectivamente. Somente no SAF2 sua importância relativa reduziu-se e 
ocorreu uma ampliação do grau de importância para outras espécies, sugerindo trata-se de uma espécie tipicamente ruderal (reprodução por semente, fácil desenvolvimento, ciclo anual e baixa capacidade de competição com outras plantas), pois a medida que aumentou o número de plantas cultivada no sistema a freqüência de $F$. annua diminuiu. Fato este verificado também para $S$. juripeba.

Nos SAF1, SAF2 SAF3, $S$. juripeba aparece como segundo colocado em freqüência, apresentando 13,$68 ; 13,72$ e $16,25 \%$ de freqüência relativa total respectivamente. No SAF4, esta espécie encontra-se em $14^{\circ}$ lugar de importância. A B. verticillata é a terceira espécies mais comum, com 12,48; 13,38 e $11,15 \%$ da freqüência relativa total nos SAFs 1,3 e 4 respectivamente. No SAF2 é a $6^{\mathrm{a}}$ colocada com $6,01 \%$, sugerindo que as freqüentes perturbações podem modificar a estrutura da comunidade, levando à substituição das espécies predominantes (Tabela 4- apêndice) por outro conjunto de espécies, com maior capacidade de regenerar após as perturbações, ou refletir na dinâmica da população de determinada espécie adaptada a ambientes mais estáveis, como as pastagens ou os sistemas com cultivos perenes.

Analisando a freqüência das 10 espécies mais importantes no SAF1, que representaram $84,92 \%$ da freqüência relativa total, observou-se que, as 4 primeiras espécies, $F$. annua, S. juripeba, B. verticillata e B. humidicola, (2 monocotiledôneas e 2 dicotiledôneas), totalizam $57,04 \%$ da freqüência relativa total e, as outras 6 restantes, $27,88 \%$; indicando a existência de poucas espécies com capacidade de colonizar este tipo de sistemas.

Para o SAF2, verifica-se que as 10 espécies mais freqüentes somam, $80 \%$ do total da freqüência relativa. Deste total, $50 \%$ estão representadas pelas 4 primeiras espécies ( $F$. annua, S. juripeba, P. multicaule e B. humidicola), e $70 \%$ das primeiras 10 espécies são monocotiledôneas, sugerindo que este sistema está sendo dominado e coberto pelas gramíneas. 


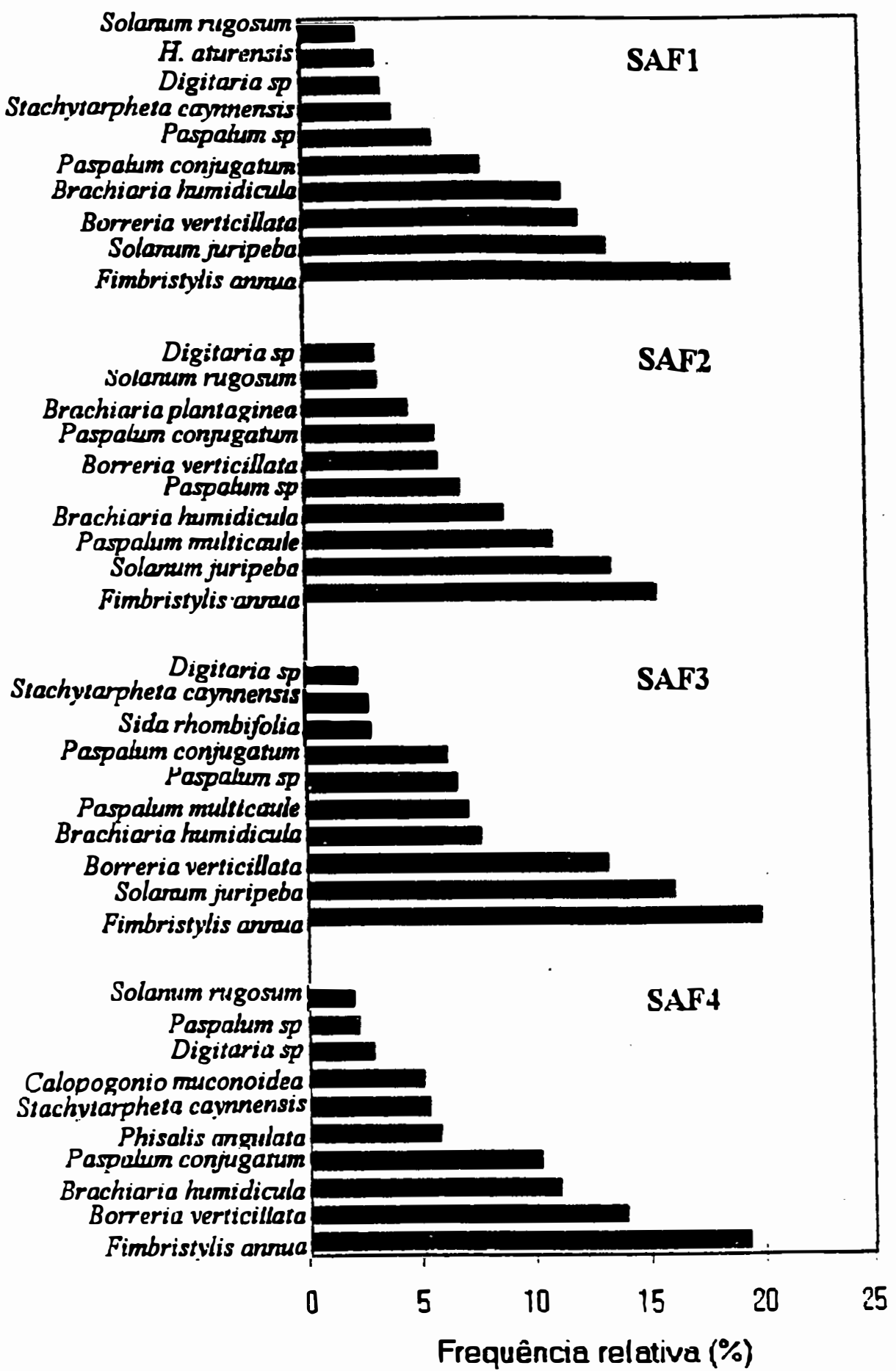

Figura 13 - Freqüência relativa (\%) das 10 espécies mais comuns nos SAF1, SAF2, SAF3 e SAF4. 
No sistema agrosilvipastoril SAF3, as 10 espécies mais importantes ocuparam $86,20 \%$ da freqüência relativa total, sendo que, as 4 primeiras (F. annua, S. juripeba, B. verticillata e B. humidicola) totalizaram $57,43 \%$. Enquanto as demais espécies (seis), representam apenas $29 \%$ da freqüência relativa total. Neste sistema (SAF3), as principais dicotiledôneas ( $S$. juripeba, B. verticillata, S. cayennensis, S. rhombifolia e R. fruticosa), ocorreram com freqüência de 37,95\%. DANTAS \& RODRIGUES (1980) relataram que estas espécies entre outras, são freqüentes nas pastagens cultivadas na Amazônia. Todas as dicotiledôneas tiveram suas freqüências reduzidas neste sistema após o estabelecimento do Desmodium ovalifolium como leguminosa forrageira, com exceção de $S$. juripeba que continua com uma freqüência relativamente alta $\left(14,91 \%\right.$ na última coleta), quando comparada com a $4^{\mathrm{a}}$ coleta $(13,10 \%)$.

Entre as 10 espécies mais freqüentes que ocorreram no SAF4 apareceram $P$. angulatum e $C$. muconoides, cujas espécies, não foram comuns nos outros sistemas (SAF1, SAF2, SAF3). Possivelmente a ocorrência destas duas espécies esteja relacionada com o histórico de manejo do solo e tipo de cultura empregado neste sistema (SAF4).

\subsubsection{Efeito dos Sistemas Agroflorestais na Fitomassa}

A fitomassa (peso da matéria seca da parte aérea das plantas invasoras) é o parâmetro analítico mais importante para avaliar este tipo de vegetação, visto que, juntamente com a freqüência e dados de concentração de nutrientes acumulados por estas plantas, pode-se prever quanto e quando estas espécies podem se tornar indesejáveis nos agroecossistemas, principalmente quando estão competindo diretamente com as plantas cultivadas pelos mesmos nutrientes disponíveis.

A fitomassa acumulada pelas invasoras foi afetada pelos SAFs, conforme mostra a Figura 14. Nota-se que os sistemas agrosilviculturais SAF2 - multiestrato $\left(130,82 \mathrm{~g} / \mathrm{m}^{2}\right)$ e SAF1 $\left(120,20 \mathrm{~g} / \mathrm{m}^{2}\right)$ proporcionaram maior acúmulo de fitomassa/aérea, enquanto que nos sistemas agrosilvipastoris SAF3 - 
baixos insumos e SAF4 - altos insumos, as médias para este parâmetro foram inferiores a $61,63 \mathrm{~g} / \mathrm{m}^{2}$ e $64,75 \mathrm{~g} / \mathrm{m}^{2}$, respectivamente.

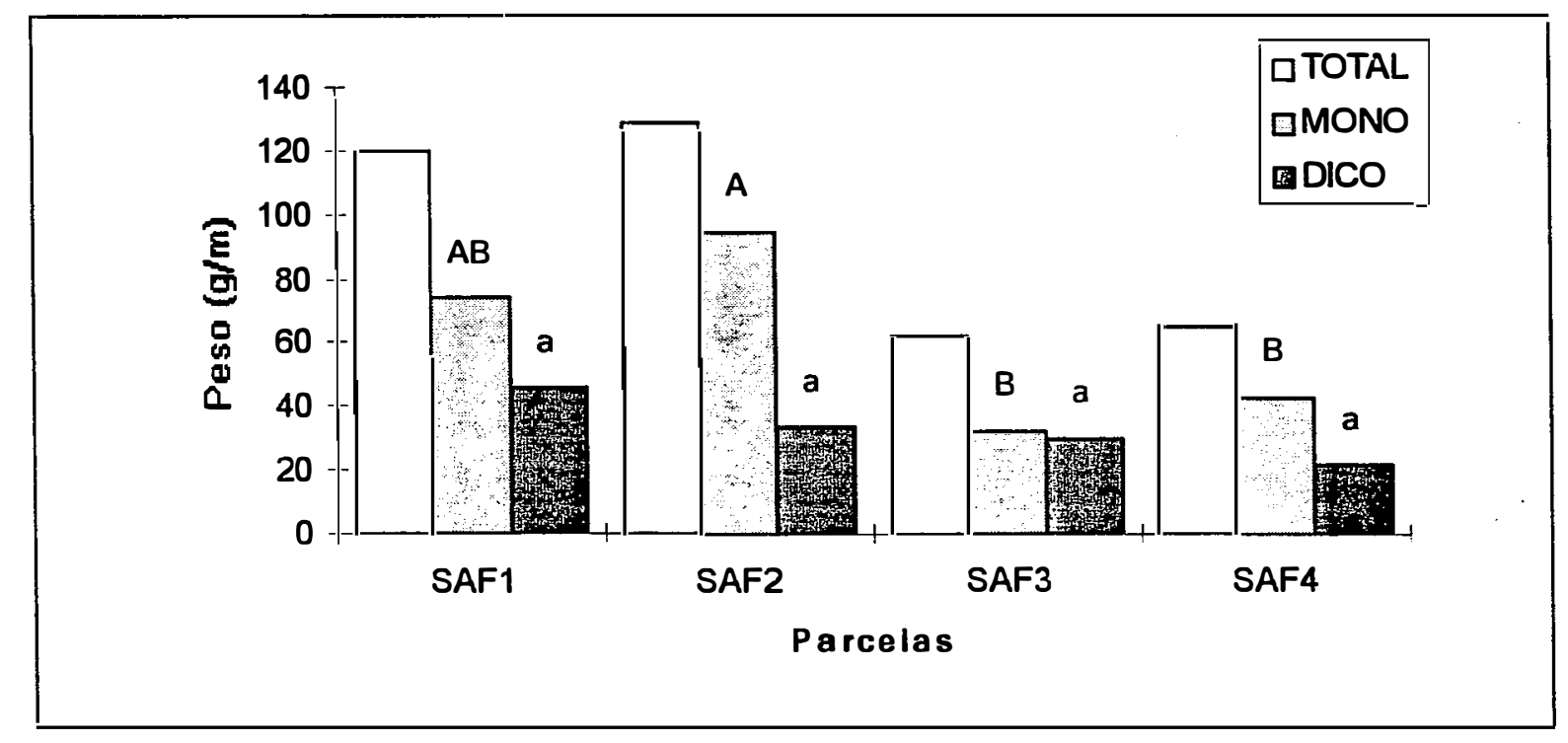

Figura 14 - Fitomassa das plantas invasoras nas parcelas, SAF1=sistema agrosilvicultural 1; SAF2=sistema agrosilvicultural 2multiestrato; SAF3=sistema agrosilvipastoril - baixos insumos e SAF4=sistema agrosilvipastoril - altos insumos. Médias seguidas da mesma letra não diferem significativamente entre si, ao nível de $5 \%$ de probabilidade pelo teste de Tukey.

Estes dados parecem indicar que um conjunto de fatores bióticos e abióticos, como por exemplo mudança nas condições físicas e químicas do solo, histórico do manejo nas parcelas e estratégias de chegada e estabelecimento das espécies invasoras, devem ter influenciado na dinâmica da fitomassa destas plantas nos sistemas. De acordo com Goldeberg \& Kigel (1986), citados por GARCIA (1988), a interferência de interações bióticas, juntamente com variações nas amplitudes de tolerância das espécies componentes da comunidade invasora, podem levar a modificações da estrutura das comunidades e à substituição de espécies predominantes, quando uma nova condição no ambiente é imposta.

No $\mathrm{SAF} 2$ e SAF1, a fitomassa variou da $1^{\mathrm{a}}$ coleta à $5^{\mathrm{a}}$ coleta, ao longo dos 18 meses de observação mostrando, de maneira geral, que a 
intensifícação do uso e manejo dos solos, com culturas agrícolas de ciclo curto proporcionou um aumento no peso de fitomassa aérea das invasoras, principalmente no SAF2, cujo sistema assemelha-se ao sistema (quintal) do pequeno produtor amazônico. Neste sistema procurou-se aumentar, seqüencialmente, o número de plantas cultivadas/ha, enriquecendo o sistema com plantios arbóreos, ocupando as entrelinhas com cultivos de ciclo curto. Esses sistemas proporcionam uma melhoria em relação ao sistema tradicional de produção do pequeno produtor da Amazônia, baseado nas produções das fruteiras perenes e semi-perenes.

A quantificação da fitomassa das invasoras que ocorreram nestes sistemas ao longo do tempo pode, também, indicar a dimensão do problema enfrentado pelos produtores da região, com as plantas invasoras. E deve explicar, em parte, por que os produtores que não têm condições de arcar com mão-de-obra ou custear as despesas com manejo das plantas invasoras, aliado ao alto custo dos fertilizantes químicos, abandonam suas áreas de produção. PLEASANT et al. (1990) estudando a dinâmica de espécies invasoras em Yurimaguas no Peru, concluíram que a produção intensiva nessa região é possível somente com um programa de controle efetivo das plantas invasoras. Porém, isso pode ser economicamente inviável, devido aos custos com insumos e mão-deobra.

A Figura 15 mostra dados de fitomassa relativa das 10 espécies mais importantes do SAFs 1, 2, 3, e 4. Através desse parâmetro pode-se observar com maior clareza a importância de cada espécie ou conjunto de espécies que poderão se tornar espécie-problema nos sistemas e, estas informações ampliam as possibilidades de manejar estas plantas em sistemas agroflorestais a custos mais reduzidos, visto que pode-se concentrar maior esforço nas espécies mais problemáticas. As 10 espécies de maior importância em fitomassa relativa, acumularam, em média, durante os 18 meses de observação, $93,75 \%, 88,20 \%, 90,10 \%$ e $90,19 \%$ nos SAF1, SAF2, SAF3 e SAF4, respectivamente. 
A espécie $S$. juripeba foi a invasora de maior importância para os SAF1, SAF2 e SAF3, sendo mais problemática no SAF3, cuja fitomassa relativa foi de $31,06 \%$ do total. No SAF1 acumulou $27,73 \%$ e no SAF2 $23,22 \%$, da fitomassa relativa total. No SAF4 esta espécie aparece em $13^{\circ}$ lugar de importância, neste parâmetro e, isto deve ter sido provocado pela gradagem realizada neste sistema para o plantio do milho, feijão e mandioca, que pode ter reduzido os propágulos vegetativos desta planta, quebrando o seu potencial de infestação através deste mecanismo. DIAS FILHO (1990) relaciona a gradagem como um método de controle de plantas invasoras para melhorar o estabelecimento das pastagens.

No SAF1 as 3 primeiras espécies (S. juripeba, B. humidicola e F. annua) acumularam $61,23 \%$ da fitomassa relativa total do sistema. As outras 7 espécies acumularam 32,52\%, indicando que as 10 espécies são dominantes neste sistema. Embora B. humidicola, F. annua, Paspalum sp, Digitaria sp e $S$. cayennensis e $S$. rugosum estejam entre as 10 mais importantes, elas apresentam tendência a diminuírem sua ocorrência neste sistema visto que, na $4^{\mathrm{a}}$ coleta foi verificada uma fitomassa relativa de $67,16 \%$ para estas espécies e em set/94 ( $5^{\mathrm{a}}$ coleta) somavam apenas $34,94 \%$.

Por outro lado, a $S$. juripeba, $P$. conjugatum e $H$. aturensis tiveram suas participações aumentadas de $19,00 \%$ para $52,46 \%$ da fitomassa relativa total, neste mesmo período. $B$. verticillata permaneceu com sua freqüência estável e sua fitomassa relativa em torno de $6,9 \%$. A volta de $B$. humidicola e a chegada de $P$. conjugatum e $H$. aturensis (gramíneas nativa) pode ser encarada com pouca preocupação, visto que, este sistema permite que esta vegetação possa ser utilizada por pequenos animais, tipo ovinos e caprinos, que poderão manter sob controle estas invasoras, ou passarem a ser controladas por roçagem, que é uma tarefa mais fácil de ser executada do que as capinas. OLADUKUN (1989) sugere o pastejo de ovinos, caprinos e bovinos nas entrelinhas dos SAFs para manter a vegetação invasora sob controle. 


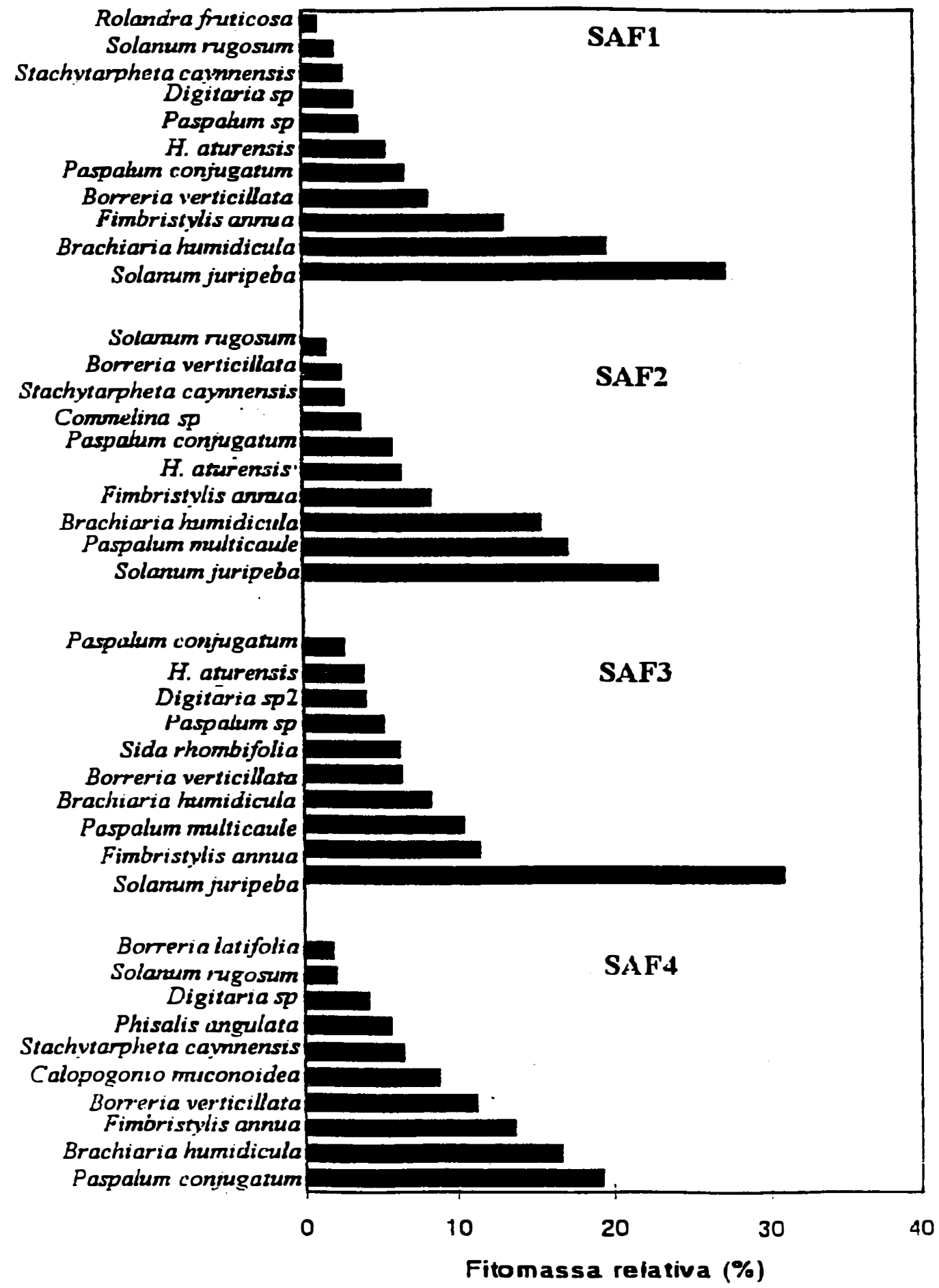

Figura 15 - Fitomassa relativa (\%) das 10 principais espécies nos SAFs. 
As espécies $S$. juripeba, $P$. multicaule e $B$. humidicola são as mais importantes do sistema em termos de fitomassa e concentraram juntas $56,45 \%$ da fitomassa relativa total. Deste total, $23,22 \%$ foram acumulados pela espécie $S$. juripeba, que apesar de ter sido registrado um aumento do peso da matéria seca em set/94 $\left(4,91 \mathrm{~g} / \mathrm{m}^{2}\right)$, apresenta redução gradativa no SAF2 a medida que a densidade das plantas cultivadas aumentam no sistema.

Apesar do nível de perturbação que ocorre nesta parcela (SAF2) $S$. juripeba, juntamente $\operatorname{com} B$. humidicola, Paspalum sp, $P$. conjungatum e Commelina sp, que possuem a estratégia de se estabelecerem através de rebrotamento, parece representar uma comunidade madura, com menor número de indivíduos adultos, porém vigorosos. GARCIA (1988) considera que as espécies que apresentam uma certa uniformidade no tempo, em função da grande capacidade de recolonização após as perturbações apresentaram "resiliência" de acordo com o conceito de Leps et al. (1982) citado pela autora. Tais estratégias de adaptação permite que essas espécies respondam prontamente às perturbações provocada pelo homem nos agroecossientamas.

$\mathrm{O}$ aumento da fitomassa relativa das 10 principais invasoras, em set/94 ( $5^{\mathrm{a}}$ coleta) no SAF2 (com exceção de Paspalum sp, $F$. annua $e$ Paspalum multicaule que apresentaram uma redução em suas fitomassas neste período) deve ser encarado com muita preocupação, visto que, a maioria das plantas frutíferas de porte baixo, tipo araçá-boi e acerola, estão em fase de crescimento e necessitam serem mantidas no limpo.

Para o SAF2, a médio e longo prazos, acredita-se que o sombreamento provocado pelas espécies arbóreas (castanha-do-brasil, teca e mogno) possam exercer influência negativa na ocorrência das plantas invasoras, pois a maioria dessas não toleram sombreamento.

Para os 2 sistemas agrosilvipastoris SAF3 e SAF4, o aumento da fitomassa das plantas consideradas invasoras, principalmente das monocotiledôneas, pode ser encarado como um aspecto positivo, visto que o objetivo do sistema é a formação de pastagens com gramíneas e outras forrageiras. Entretanto, a fitomassa nestes dois sistemas, foi bem menor do que 
nos sistemas agrosilviculturais (SAF1 e SAF2). O SAF3 apresentou $61,63 \mathrm{~g} / \mathrm{m}^{2} \mathrm{de}$ matéria seca da fitomassa aérea das invasoras e o SAF4 $64,75 \mathrm{~g} / \mathrm{m}^{2}$, contra 120,2 $\mathrm{g} / \mathrm{m}^{2}$ do SAF1 e $130,83 \mathrm{~g} / \mathrm{m}^{2}$ do SAF2.

No SAF3, das 10 espécies mais importantes que acumularam $90,10 \%$ da fitomassa relativa total, $80 \%$ são monocotiledôneas e, juntas, aumularam 52,63\% da fitomassa relativa total. Entretanto, a espécie de maior importância deste parâmetro, é $S$. juripeba que, acumulou 31,06\% da fitomassa relativa total. O aumento da fitomassa verificada na $S$. juripeba, sugere que o Desmodium ovalifolium implantado nas faixas mais largas do sistema (linhas triplas arbóreas), não interferiu na freqüência e redução da fitomassa desta espécie. Contudo, foi observado uma redução na biomassa das demais dicotiledôneas como, B. verticillata e $S$. rhombifolia. A B. humidicola apesar de aparecer entre as 4 espécies mais importantes, com $8,45 \%$ do total da freqüência relativa, após o estabelecimento do $D$. ovalifolium, teve sua fitomassa reduzida acentuadamente no decorrer do período. Em mar/94 ( $4^{\mathrm{a}}$ coleta), foi registrado $23,82 \%$ de fitomassa relativa e, set/94 somente $4,94 \%$. Em compensação as gramíneas nativas (Digitaria sp2, $H$. aturensis e $P$. conjugatum) aumentaram sua participação representando juntas $10,54 \%$ da fitomassa relativa total neste sistema.

Nas linhas triplas de ingá $\mathrm{x}$ mogno $\mathrm{x}$ paricá do SAF3 o crescimento das invasoras foi gradativamente sendo reduzido, à medida que as árvores foram crescendo e sombreando o estrato inferior do sistema (Figura 16) enquanto que nas faixas entre as linhas de plantio dos componentes arbóreos a fitomassa, a partir de set/93 ( $3^{\mathrm{a}}$ coleta) passou de $61,37 \mathrm{~g} / \mathrm{m}^{2}$ para $157,06 \mathrm{~g} / \mathrm{m}^{2}\left(4^{\mathrm{a}}\right.$ coleta). Este fato decorreu no intervalo da colheita, plantio novamente da mandioca, inicio da germinação e estabelecimento do $D$. ovalifolium, nas entrelinhas da mandioca. Todavia, logo após o estabelecimento da leguminosa forrageira, a fitomassa das invasoras caiu para $97,70 \mathrm{~g} / \mathrm{m}^{2}$.

O estudo da dinâmica das invasoras no sistema Agroflorestal (SAF3), indica a importância na definição dos arranjos espaciais dos sistemas agroflorestais como forma de maximizar as pressões bioticas sobre as invasoras 
no sistema. $\mathrm{O}$ estabelecimento de espécies arbóreas, de rápido crescimento em SAFs para recuperação das pastagens degradadas na Amazônia pode ser uma alternativa viável e de baixo custo, com o manejo das plantas invasoras. Isto porque, as faixas entre as linhas dos componentes arbóreos poderá ser utilizada pelos produtores para cultivos de ciclo curto por um período mais prolongado, em vez do plantio simultâneo das forrageiras, como num sistema de cultivos em faixas (Alley cropping).

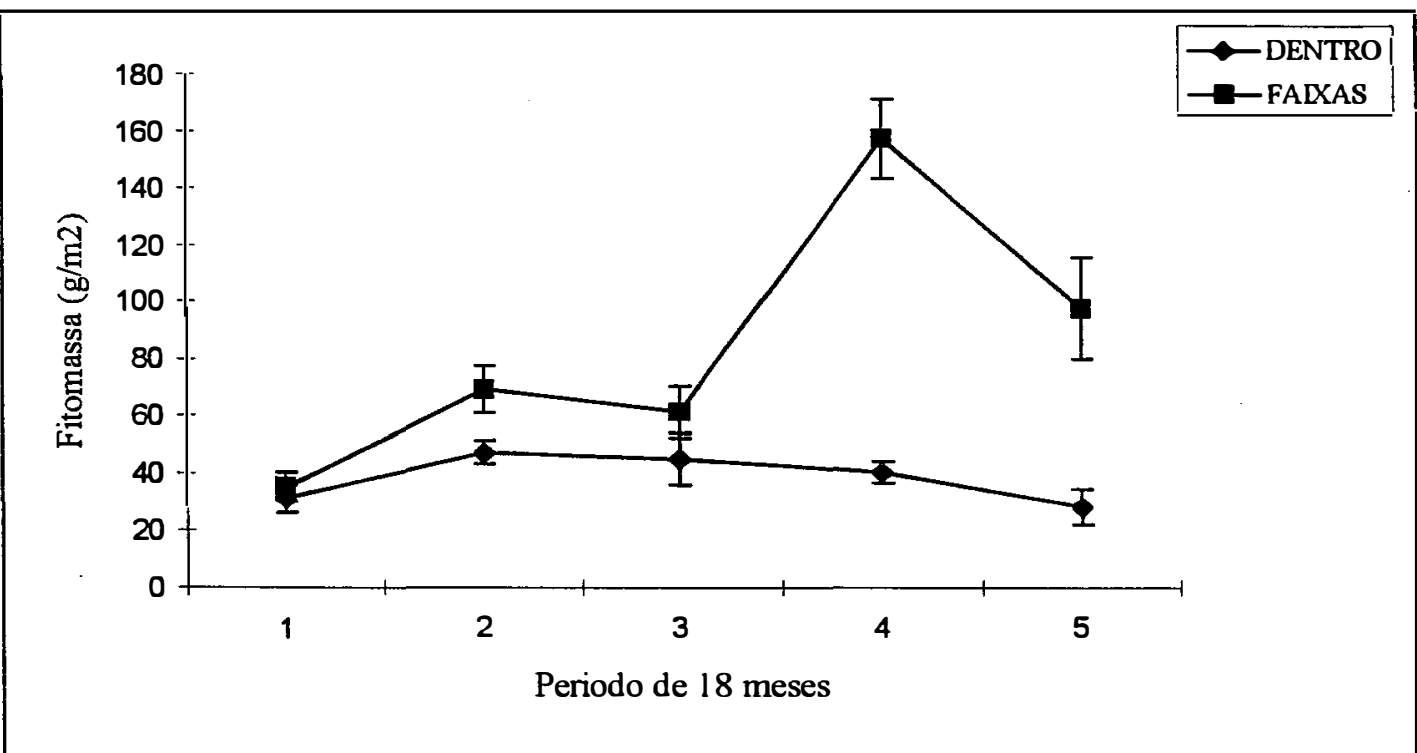

Figura 16 - Fitomassa das invasoras em $\left(\mathrm{g} / \mathrm{m}^{2}\right)$, dentro e nas faixas entre as linhas dos componentes arbóreos do SAF3 ao longo de 18 meses em 5 coletas.

O (SAF3) possui vantagens em relação aos tradicionais consórcios com espécies arbóreas, os quais apresentam um uso limitado das estrelinhas, pelo fechamento da copa das árvores. Para o pequeno produtor que não deseja formar pastagens, as linhas triplas poderiam ser compostas por espécies, frutíferas, madeireiras e leguminosas (para incremento de matéria orgânica no solo) e, as faixas ocupadas por culturas de ciclo curto em determinado período e com pousio de leguminosas herbáceas.

No SAF4 as 3 primeiras espécies de maior importância foram as gramíneas $P$. conjugatum, $B$. humidicola, $F$. annua, que acumularam 49,80\% da fitomassa relativa total. Em seguida aparece $B$. verticillata com $11,34 \%$ que 
apresentou uma tendência a decrescer no sistema, após o estabelecimento do $D$. ovalifolium. As demais 6 espécies totalizam 38,90\% da fitomassa relativa e, dentre estas, encontram-se 4 dicotiledôneas (15,93\%), consideradas invasoras tradicionais dos agroecossistemas $(S$. cayennensis, $P$. angulatum $S$. rugosum e $B$. latifolia) que merecem atenção para não se tornarem pragas.

Destaca-se, no SAF4, a presença da leguminosa forrageira Calopogonio muconoides que, junto com $D$. ovalifolium e as demais gramíneas, devem ser mantidas no sistema.

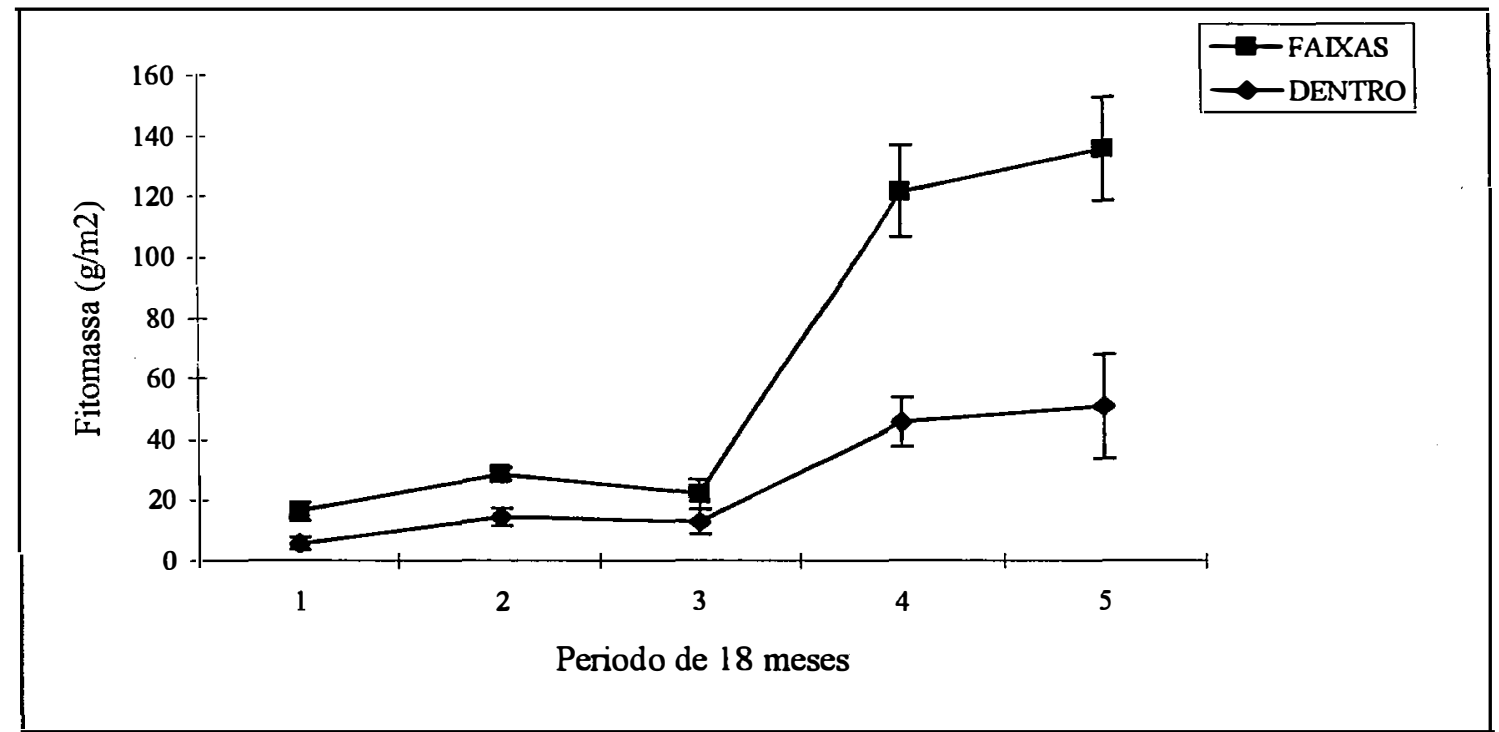

Figura 17 - Fitomassa das invasoras em $\left(\mathrm{g} / \mathrm{m}^{2}\right)$, dentro e nas faixas entre as linhas dos componentes arbóreos do SAF4 ao longo de 18 meses em 5 coletas.

Dentro das linhas das arbóreas (de ingá $\mathrm{x}$ mogno $\mathrm{x}$ paricá), do SAF4 (Figura 17), até a $3^{a}$ coleta, a dinâmica da fitomassa das invasoras foi semelhante $\left(12,7 \mathrm{~g} / \mathrm{m}^{2}\right)$, nas faixas e $9,22 \mathrm{~g} / \mathrm{m}^{2}$ nas linhas. Entretanto, após a poda da "saia" (ramos baixos) do ingá, e a colheita e replantio da mandioca, início da germinação e estabelecimento do $D$. ovalifolium nas entrelinhas da mandioca, ocorreu um aumento acentuado da fitomassa das invasoras, registrado na $4^{\mathrm{a}}$ coleta, tanto dentro das linhas $\left(45,32 \mathrm{~g} / \mathrm{m}^{2}\right)$, como nas faixas $\left(75,94 \mathrm{~g} / \mathrm{m}^{2}\right)$. Porém na $5^{a}$ coleta verificou-se uma redução no incremento da fitomassa das invasoras, tanto dentro das linhas de plantio $(5,29 \%)$, como nas faixas entre as linhas $(8,58 \%)$ registrando-se, neste período, um peso da matéria seca da fitomassa aérea 
das invasoras dentro das linhas de $50,81 \mathrm{~g} / \mathrm{m}^{2}$ e de $84,52 \mathrm{~g} / \mathrm{m}^{2}$ nas faixas. Entretanto, consideramos que, se o Desmodium fosse plantado com maior antecedência nas entrelinhas da mandioca, teria maior capacidade de competição e nas faixas ocorreriam menos invasoras.

Portanto, considerando a quantidade de fitomassa de invasoras acumulada neste sistema $\left(64,75 \mathrm{~g} / \mathrm{m}^{2}\right)$ no decorrer do período (18 meses), quando comparada aos SAF1 e SAF2, que apresentaram $\left(120,20 \mathrm{~g} / \mathrm{m}^{2}\right.$ e $130,83 \mathrm{~g} / \mathrm{m}^{2}$ respectivamente), é possível que os produtores devam ter menores custos com a mão-de-obra para controlar as invasoras neste sistema.

Porém, o SAF4, como modelo de sistema Agroflorestal, é limitado para determinados tipos de produtores, dado o elevado uso de insumos.

\subsubsection{Dinâmica das 5 espécies mais comuns nos sistemas agroflorestais}

As espécies Borreria verticillata, Brachiaria humidicola, Fimbristylis annua, Paspalum conjugatum e Solanum juripeba, são as plantas invasoras mais comuns dos sistemas agroflorestais implantados sobre pastagens degradadas na Amazônia central. Nestas condições, tais ecótipos, produziram quantidades diferentes de fitomassa ao longo de 18 meses que variaram de acordo com o tipo de manejo de cada sistema (Figura 18). Nas primeiras coletas (mar/93 e jun/93) apresentaram em comum aumento na fitomassa aérea, com exceção de P.conjugatum no SAF1 e SAF2, B. humidicola no SAF3 e B. verticillata no SAF4. Continuaram apresentando esta capacidade de aumento no incremento da fitomassa no decorrer do período da terceira para quarta coletas, com exceção de S.juripeba no SAF1 e P. conjugatum no SAF3.

Durante a segunda (jun/93) para terceira (set/93) coleta ocorreu uma diminuição na produção de fitomassa dessas 5 espécies, com exceção de B. humidicola e F.annua no SAF4, possivelmente devido o menor tempo compreendido entre as capina.Entretanto no decorrer da quarta (mar/94) para quinta (set/94) coleta observou-se que as variações para maior ou para menor produção de fitomassa foram influenciadas pelo tipo de manejo e estratégias de 
cada espécie (ecótipo) em colonizar e recolonizar os ambientes perturbados (HARPER, 1977; CHANCELLOR, 1985 e DERKSEN et al., 1993).

No sistema agrosilvicultural SAF $1, B$. humidicola e $F$. annua apresentaram uma tendência a diminuir suas presenças neste sistrema. No SAF2, $B$. verticillata apresentou comportamento semelhante. Enquanto que $B$. conjugatum, apresenta uma tendência a aumentar a fitomassa nestes sistemas.

Nos sistemas agrosilvipastoris SAF3 e SAF4, as espécies $B$. verticillata, B. humidicola e F.annua, plantas típicas de ecossistema de pastagens, apresentaram comportamento semelhante (redução de fitomassa na $5^{\text {a }}$ coleta). Em $\mathrm{mar} / 94$ somavam $42 \mathrm{~g} / \mathrm{m}^{2}$, no SAF3 e $4 \mathrm{~g} / \mathrm{m}^{2}$, no SAF4, em set/94 apresentavam somente $11 \mathrm{~g} / \mathrm{m}^{2}$ e $13 \mathrm{~g} / \mathrm{m}^{2}$ respectivamente, indicando a baixa capacidade de competição e característica ruderal principalmente da primeira e terceira espécie nas condições dos sistemas agroflorestais.

A espécie $B$. verticillata permaneceu estável ao longo dos primeiros 7 meses da coleta (até $3^{\text {a }}$ coleta) e aumentou a sua produção de fitomassa na $4^{a}$ coleta em todos os sistemas, já durante a quinta coleta variou para menor acumulo fitomassa nos SAF2, SAF3 e SAF4. No SAF1 a permanência desta espécie foi tolerada, devido a menor densidade de plantas cultivadas neste sistema.

A espécie S.juripeba, foi a que apresentou produção de fitomassa relativamente alta (Tabela 12) nos SAF1, SAF2 e SAF3. No SAF4 devido o manejo do solo (gradagem) para o plantio das culturas de ciclo curto (milho, feijão e mandioca) a sua presença foi notada na quinta coleta quando o sistema estava entrando numa fase mais equilíbrada com o plantio permanente das plantas forrageiras e as árvores formando copa.

No SAF3 devido a sua frequência e produção de fitomassa pode ser considerada espécie-problema que poderá ser encarada de duas maneira: a primeira como uma planta invasora capaz de trazer prejuízo ao homem e nesta situação deverá ser eliminada do sistema. Entretanto, quando observamos a capacidade e quantidade de nutrientes que este ecótipo possui (Tabela12), podemos tomar a decisão de mantê-los no sistema como uma fonte de material 
orgânico no solo e nitrogênio. Esta produção de fitomassa pode ser redistribuida no sistema em benefício das plantas cultivadas. DENICH (1991) sugere o uso desta forma de biomassa nos sistemas do pequeno produtor como forma de manter a fertilidade dos solos em condições de produções estáveis ecológica e econômica.

As 5 espécies acumularam juntas $74,54,59$ e $63 \%$ do total da fitomassa produzida nos SAF1, SAF2, SAF3 e SAF4 respectivamente (Tabela 12). Dentre as cinco observa-se que $S$. Juripeba e $B$. verticillata, destacaram-se na concentração e acúmulo de N, P e Ca. Para potassio (K), somente S. juripeba apresentou em todos os sistemas percentuais relativamente bem definidos, enquanto, para magnésio $(\mathrm{Mg})$ foi P.conjugatum que apresentou percentuais definidos nos SAF1, SAF2 e SAF4.

As quantidades de nitrogênio acumulado pelas 5 espécies foram na ordem de 15,$33 ; 11,56 ; 7,685,05 \mathrm{~kg} / \mathrm{ha}$ por capina para os SAF1, $\mathrm{SAF} 2, \mathrm{SAF} 3$ e SAF4 respectivamente. Estes resultados indicam a capacidade destas espécies em acumularem diferentes níveis de nutrientes e pode representar vantagens econômicas para o produtor na hora de adquirir fertilizantes químico, principalmente para nitrogênio e fósforo. A espécie $S$. juripeba, sozinha apresentou um conteúdo de $\mathrm{N}$ no SAF1, de $7,32 \mathrm{~kg} / \mathrm{ha}$. Considerando que o produtor faça duas capinas por ano os recursos em nitrogênio nesta biomassa duplicam para $14 \mathrm{~kg} / \mathrm{ha} /$ ano.

Portanto a produção de fitomassa das plantas invasoras com estoque de nutrientes elevados não pode ser desperdiçadas. Após cada capina a fitomassa das invasoras deverá ser redistribuida para as linhas das plantas cultivadas como uma fonte de nutriente, evitando assim, que esta fitomassa permaneça sobre as partes vegetativas das plantas invasoras favorecendo a reinfestação da espécie na área. A distribuição deste material deve funcionar como uma forma de controle das plantas invasoras, além de representar uma fonte de nutrientes que possui um valor econômico, que deve ser compensados entre os custos de capinas e compra de fertilizantes. 


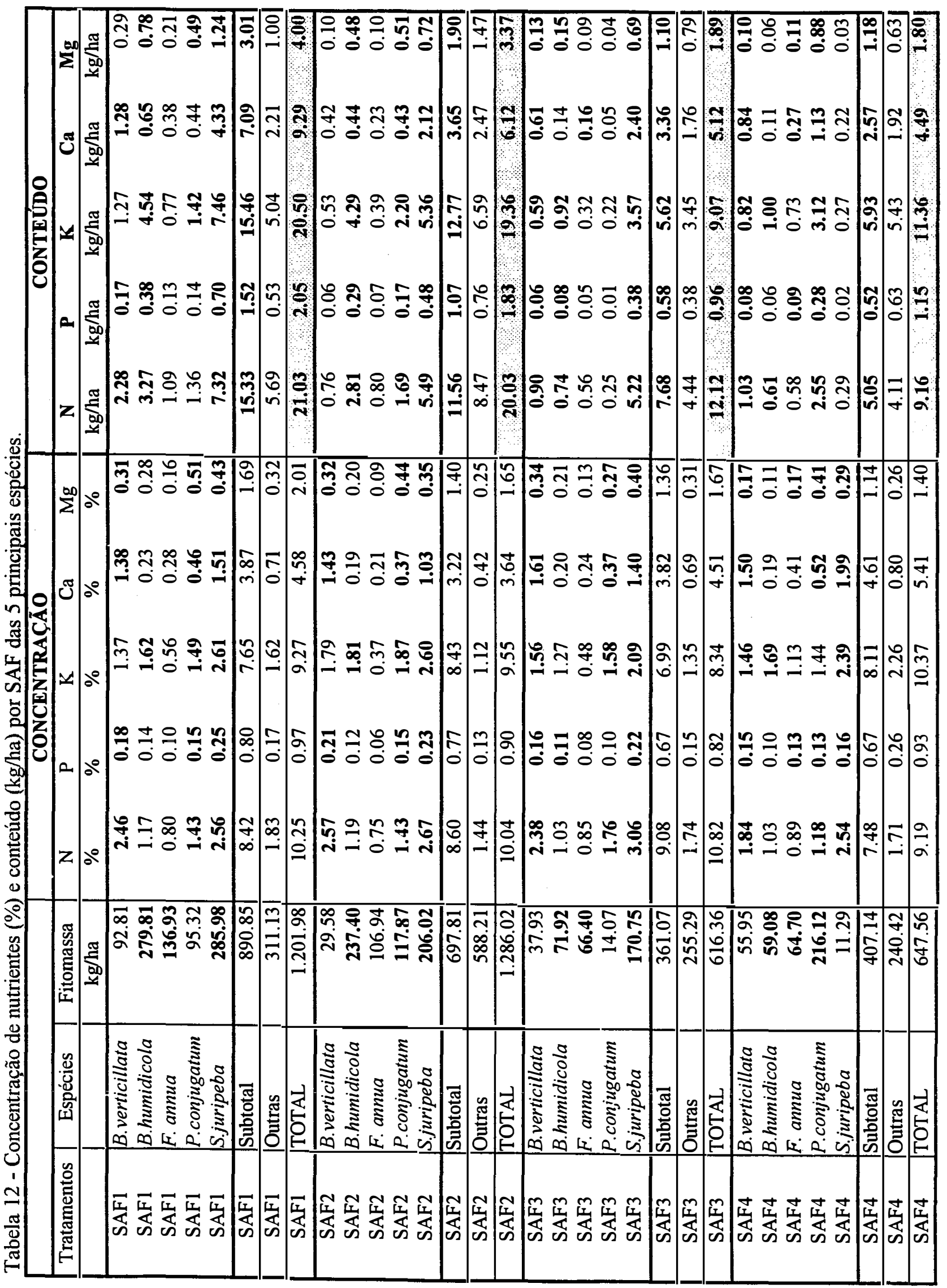



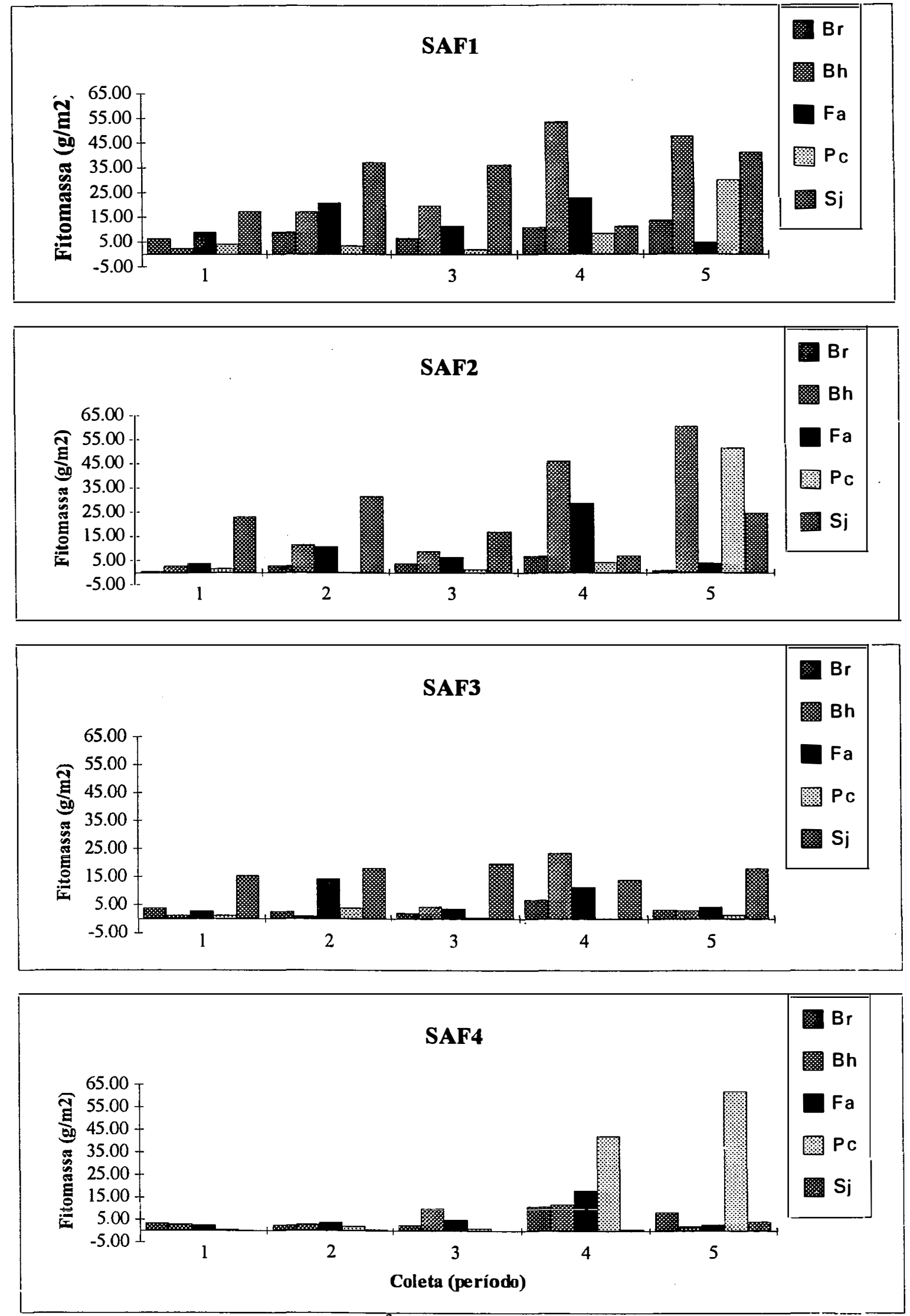

Figura 18 - Dinâmica da fitomassa $\left(\mathrm{g} / \mathrm{m}^{2}\right)$ das 5 espécies mais comuns $\mathrm{Br}$ (Borreria verticillata), $\mathrm{Bh}$ (Brachiaria humidicola), Fa (Fimbristylis annua), Pc (Paspalum conjugatum) e Sj (Solanum juripeba). 


\section{CONCLUSÕES}

De acordo com o levantamento florístico, as comunidades de plantas invasoras que ocorrem no estrato inferior dos sistemas agroflorestais são formadas por 63 espécies, distribuídos em 40 gêneros e 18 famílias botânicas. As monocotiledôneas formadas pelas famílias Poaceae, Cyperaceae e Commelinaceae foram dominantes na área em densidade, frequência e fitomassa. As dicotiledôneas ocuparam o segundo plano com menor densidade, maior diversidade de espécies, indivíduos mais pesados e concentraram maiores porcentagens de macro nutrientes ( $\mathrm{N}, \mathrm{P}, \mathrm{K}, \mathrm{Ca}$ e $\mathrm{Mg}$ ).

As comunidades de plantas invasoras nos sistemas foram originadas principalmente por sementes, apesar do número de rebrotos terem aumentado significativamente ao longo dos 18 meses, principalmente das monocotiledôneas.

As monocotiledôneas apresentaram mais de $50 \%$ dos indivíduos em fase de floração e frutificação e, as dicotiledôneas apresentaram uma comunidade com indivíduos mais jovens ( sem floração e frutificação).

As familias Poaceae, Cyperaceae, Solanaceae, Rubiaceae e Verbernaceae, representadas pelas dez primeiras espécies de maior índice de valor de importância (IVI), formaram a base das comunidades de invasoras.

Entre as 10 primeiras espécies de maior IVI destacaram-se: Solanum juripeba, Fimbristylis annua, Brachiaria humidicola, Paspalum multicaule, Borreria verticillata e Paspalum conjugatum, que apresentaram valores acima da média para densidade, ou frequência, ou fitomassa. 
As comunidades mais semelhantes foram (SAF1 x SAF2), (SAF1 x SAF4) e (SAF2 x SAF4), com índices de similaridade maiores que 56\%. As comunidades de plantas invasoras presentes nos sistemas agroflorestais apresentaram semelhanças com as das pastagens em apenas 26 a 38\% pelo Índice de Similaridade de Jaccard..

Os sistemas agroflorestais não influenciaram na densidade de plantas invasoras que ocorreram no estrato inferior, porém observou-se uma maior densidade no SAF2.

A fitomassa aérea acumulada pelas plantas invasoras no SAF2 foi superior a dos SAFs 3 e 4 . As espécies que mais contribuíram para o aumento da fitomassa aérea nos sistemas foram Solanum juripeba, Paspalum conjugatum e Brachiaria humidicola. No SAF4 devido o manejo do solo (gradagem, calagem e adubação), as densidades e fitomassa de Solanum juripeba foram menos intensivas.

Os SAF3 e SAF4 contribuíram para uma menor densidade e fitomassa das plantas invasoras, indicando a importância dos arranjos espacias na definição dos sistemas agroflorestais, com vista a uma menor ocorrência de plantas invasoras.

O estudo da dinâmica da comunidade de plantas invasoras esclareceu relativamente como esta vegetação está ocorrendo, que direção está tomando o que possibilita as tomadas de decisões para o manejo de sistemas agroflorestais a serem implantados, em áreas semelhantes às estudadas.

\subsection{Perspectivas para o manejo de plantas invasoras em sistemas agroflorestais na Amazônia}

$\mathrm{Na}$ Amazônia, os sistemas agroflorestais deverão se adotados tanto pelo produtor que pratica agricultura itinerante, como pelo produtor que derruba a floresta para implantação de pastagens. Portanto, tais sistemas deverão responder à objetivos imediatos do agricultor descapitalizado e de subsistência, 
com produções mínimas de alimentos para sua sobrevivência e colheitas periódicas a médio e longo prazo na mesma área, visando melhorar sua qualidade de vida, sem a necessidade de provocar novos desmatamentos na floresta.

Para o médio e grande produtores, principalmente os pecuaristas, os sistemas agroflorestais deverão responder por colheitas que possam pagar os investimentos iniciais de implantação desses sistemas e permitir o manejo mais adequado das pastagens, em consonância com os componentes arbóreos, objetivando garantir a produtividade a médio e longo prazos numa determinada área, sem a necessidade de abandoná-la e provocar novos desmatamentos.

Entretanto, os sistemas agroflorestais, não estão isentos da interferência das plantas invasoras que, aliada aos elevados custos para recuperação da fertilidade dos solos, constituem-se em problemas sérios para implantação dos sistemas na região.

$\mathrm{Na}$ Amazônia, PLEASANT et al. (1990) relatam que as condições físicas e sócio econômicas são fatores limitantes que afetam o manejo das plantas invasoras na tradicional agricultura nos trópicos úmidos. Por outro lado, práticas e conhecimentos desenvolvidos em regiões temperadas não são totalmente transferíveis, visto que, na maior parte da Bacia Amazônica, água e temperatura não são fatores limitantes no crescimento das plantas em qualquer época do ano. Consequentemente as plantas invasoras crescem continuamente intensificando os problemas para seu controle. A produção intensiva das culturas agrícolas na região é possível, desde que haja um programa de controle efetivo das plantas invasoras.

O controle efetivo dessas plantas, depende da integração entre fertilidade do solo, manejo da disponibilidade de água, práticas culturais (preparo do solo, espaçamento, plantitio, controle das pragas e doenças, entre outros), rotação dos cultivos, seqüência dos plantios, escolha dos cultivares, capacitação da mão-de-obra, tração e investimento de capital (BANTILAN et al., 1974). Em sistemas agroflorestais, o manejo das plantas invasoras pode envoiver o uso de vários tipos de métodos de controle e combinações entre eles. No 
entanto, com base na literatura atual e nos resultados obtidos no presente estudo, sugere-se que, o controle preventivo em combinação com vários métodos (de acordo com a disponibilidade de mão-de-obra e potencialidade da propriedade), o tipo de sistema de cultivo e a cobertura permanente do solo, devem proporcionar o controle efetivo das plantas invasoras em sistemas agroflorestais.

O controle preventivo é uma medida que objetiva evitar a chegada de novas espécies invasoras e reduzir a capacidade de reinfestação das plantas residentes. PITELLI (1986) considera as medidas preventivas sob dois aspectos: primeiro, impedindo que as populações de plantas daninhas presentes, incrementem suas populações e, segundo, evitando a introdução de novos diásporas. Para ser evitada a entrada de novas plantas invasoras é necessário o uso de sementes e de mudas certificadas livres de qualquer estrutura reprodutiva de plantas invasoras.

Na Amazônia, estas recomendações são pouco observadas. Desta forma o produtor terá que obter sementes de fontes conhecidas ou fazer a limpeza através da catação manual (nos pequenos lotes) ou através de uma peneira, que deverá eliminar as sementes menores ou maiores do que as da cultura. Entretanto, no caso do arroz vermelho e outros casos semelhantes este último método não funciona.

Nas mudas de espécies arbóreas e arbustivas, o produtor deverá utilizar terriço (terra preta para encher as sacos) obtido em locais com vegetação conhecida e isentos de plantas invasoras. Deverä manter os viveiros sempre limpos e livre de invasoras, para evitar a contaminação por diásporos, nas sacolas com as mudas, principalmente por euphorbiaceas, ciperaceas, poaceas e asteraceas, como foi observado no viveiro de mudas da Estação Experimental da EMBRAPA (no km 54

da BR 174).

As propriedades que dispõem de máquinas e implementos agrícolas e florestais devem evitar o tráfego desses equipamentos de uma área para outra sem a devida limpeza. As rodas do tratores, arados, grades, sulcadores, enxadas, roçadeiras, entre outros, deverão estar livres dos torrões de terra e 
freqüentemente, se possível, lavados quando forem transferidos de uma área para outra.

Os estercos e outros compostos devem estar bem curtidos e livres de diasporas. Também deve ser considerado como controle preventivo a aração, gradagem e calagem, como forma de reduzir os propágulos das invasoras que se reproduzem vegetativamente. A gradagem reduz a densidade de certas espécies do gênero Solanum, Vismia, Borreria e Cyperus. A calagem por sua vez reduz a germinação de sementes de plantas que têm suas emergências influenciadas negativamente após a correção dos solos como, Imperata brasiliensis, Pteridium aquilium e Andropogon bicornes, comuns na região.

A eliminação ou erradicação de plantas invasoras tóxicas e persistentes, que ocorrem isoladamente ou em pequenas colônias nos sistemas agroflorestais, é um meio de prevenção da infestação e estabelecimento destas plantas na área, como é o caso do Paspalum virgatum e Paspalum maritimo, Cyperus, Lantana Câmara, Solanum rugosum, Solanum grandiflorum e Palicourea sp.

Nos sistemas de baixos insumos, em áreas de vegetação secundária, a queima da fitomassa no início da implantação contribui para destruição dos propágulos e sementes de espécies invasoras, reduzindo a biomassa dessas plantas na área. Esse tipo de manejo, em combinação com a cobertura viva (leguminosa de crescimento rápido como a mucuna, centrosema, feijão de porco, feijão caupi, amendoim ou guandu plantado adensado) implantada logo após as queimadas (no intervalo compreendido entre as queimadas e plantio dos componentes agroflorestais, por um período de 3 à 5 meses), impedem as germinação e rebrotos de plantas que sobreviveram ao fogo. Além disso, essa cobertura contribui para o armazenamento dos nutrientes disponíveis no solo (provenientes das cinzas), diminuindo suas perdas por lixiviação e fixando nitrogênio do ar.

Capinas e roçagens são as práticas mais usadas pelos produtores da região, principalmente, as realizadas manualmente. Nos sistemas agroflorestais, dos pequenos produtores, essas práticas deverão ser recomendadas 
em combinação com a cobertura morta ou viva e de acordo com sua capacidade de mão-de-obra familiar. Para os demais produtores a adoção dessas práticas depende da disponibilidade de mão-de-obra e de recursos financeiros destinados para este fim.

A cobertura morta proveniente das capinas, restos de culturas e de fitomassa de plantas(mantidas no sistema, destinadas para este fim) deverá ser uma rotina nos sistemas agroflorestais, objetivando manter as emergências das plantas invasoras sobre controle e incrementar a matéria orgânica no solo.

A fitomassa para cobertura morta poderá ser obtida através de plantas cultivadas dentro dos sistemas (ingá, gliricídea, acácia siamea, entre outras) ou de plantas da vegetação secundária em áreas mantidas próximas dos sistemas, (DENICH, 1991), como por exemplo as capoeiras de Vismias das pastagens abandonadas como ocorre na Amazônia Central

De acordo com a finalidade dos sistemas, o produtor poderá lançar mão da combinação de diferentes tipos de manejo que deverão ser realizados de forma eficiente e em beneficio das plantas cultivadas. Em sistemas de policultivos, com espécies arbóreas e perenes e uso temporário das entrelinhas com cultivos de ciclo curto, as recomendações preconizadas por CARVALHO \& TORRES (1994) que são baseadas na rotação dos cultivos anuais, cobertura do solo e sombreamento das árvores, na fase adulta, são eficientes e de fundamental importância em sistemas agroflorestais na Amazônia.

Porém, estes sistemas apresentam un período limitado de uso das entrelinhas, devido ao fechamento das copas das árvores, qué é uma desvantagem para o produtor que sobrevive e necessita de colheitas anuais de grãos e raízes como arroz, feijão, mandioca, batata doce, entre outros. A vista dessa necessidade o agricultor é obrigado a continuar desmatando a floresta, para fazer a sua roça (sistema de produção baseado no corte e queima da floresta, plantio de culturas anuais, abandono para o pousio e regeneração da floresta) e continuar produzindoatravés sistema denominado de agricultura itinerante.

Os cultivos em faixas, com linhas triplas de espécies arbóreas e faixas para produção contínua de pastagens ou culturas anuais, oferecem 
vantagens em relação aos tradicionais consórcios com plantas perenes, tanto para pequenos produtores, como para os pecuaristas que precisam de áreas permanentes para o cultivo de pastos ou cultivos anuais. Tais sistemas, apresentam vantagens de uso da terra por um período mais longo, diminuindo assim, a pressão de desmatamento sobre a floresta, além de contribuirem para menor produção de fitomassa de plantas invasoras. DEUBER (1991) menciona que as fileiras de árvores utilizadas como quebra-vento, nos agroecossistemas convencionais, apresentam benefícios adicionais por reduzirem a disseminação de diásporos e ocorrência de plantas invasoras. No presente trabalho, as fileiras triplas de componentes arbóreos, nos sistemas SAF3 e SAF4, reduziram de 30 à $50 \%$ a produção de biomassa das invasoras. Nesses sistemas, o manejo das invasoras deverá estar associado: ao arranjo espacial das espécies arbóreas e arbustivas, ao manejo preventivo, à cobertura permanente do solo e também ao manejo recomendado por CARVALHO \& TORRES (1994), constituindo-se numa forma eficiente de diminuir a ocorrência de plantas invasoras, à custo mais reduzidos.

Diante do exposto, conclui-se-se que o manejo das plantas invasoras em sistemas agroflorestais, não deve ser encarado isoladamente, mas sim como parte do planejamento para implantação dos sistemas, cujas relações custo-benefício, de acordo com cada sistema, deverá ser avaliado, no sentido de otimizar a produção e minimizar os investimentos financeiros que envolvem a implantação e manutenção dos sistemas. 


\section{REFERÊNCIAS BIBLIOGRÁFICAS}

AKOBUNDU, I. O. Weed control strategies for multiple cropping systems of the humid and sudhumid tropcs. In: Okobundu, I. O., ed. Weeds and their control in the humid and subumid tropics., Ibadan, IITA, 1980. p.80-100.

ALBUQUERQUE, J. M. Estudo morfológico da semente e sua germinação até à fase de plântula, principalmente de plantas invasoras de culturas e de essências florestais da Amazônia. Manaus, 1987. 137 p. (Doutorado Instituto Nacional de Pesquisa daAmazônia/Fundação Universidade do Amazonas).

ALBUQUERQUE, J. M. Identificação de plantas invasoras de culturas da região de Manaus. Manaus, 1978. 124 p. (Mestrado - Instituto Nacional de Pesquisa daAmazônia/Fundação Universidade do Amazonas).

ALMEIDA, N. N. \& RODRIGUES, M. Z. Guia de herbicidas; contribuição para o uso adequado em plantio direto e convencional. Londrina, IAPAR, 1985. $468 p$.

ALTIERI, M. A. Agroecologia; as bases cientificas da agricultura alternativas. Rio de Janeiro, PTA/FASE, 1989. 240 p.

ALTIERI, M. A. Weed manegement in agroecosystems; ecological approaches. Florida, CRC Press, 1988. 216p. 
ALTIERI, M. A. \& LIEBMAN, M. Insect, weed and plant disease management in multiple cropping systems. In: FRANCIS, C., ed. Multiple cropping systems. New York, Macmillan Publ., 1986. p.183-218.

AZEVEDO, D. M. P. \& COSTA, N. L. Plantas daninhas na cultura da seringueira, em Rondônia. In: CONGRESSO BRASILEIRO DE HERBICIDAS E PLANTAS DANINHAS, 18., Brasilia, 1991. Resumos. Brasilia, SBHED, 1991.

BANZATTO, D. A. \& KRONKA, S. N. Experimentação agrícola. Jaboticabal, FUNEP, 1992. $247 \mathrm{p}$.

BENITES, J.R. \& SANCHEZ, P.A. Central experiment; transition to other technologies. In: SANCHEZ, P. A., coord. TropSoil technical report 1986-1987. Raleigh, North Carolina State University/Department of Soil Science/Tropical Soils Research Program, 1989.

BLANCO, H. G. A importância dos estudos ecológicos nos programas de controle das plantas daninhas. O Biológico, São Paulo, 38 (10) : 345-50, 1972.

BLANCO, H. G. Ecologia das plantas daninhas; competição de plantas daninhas em culturas brasileiras. In: MARCONDES, D.A.S. et al. Controle integrado de plantas daninhas. São Paulo, CREA-SP, 1985. p.43-74.

BLANCO, H. G. Manejo de plantas daninhas; uma abordagem ecológica. In: SIMPÓSIO DE AGRICULTURA ECOLÓGICA,1., Campinas, 1993. Anais.. Campinas, Fundação Cargill, 1993. p. 67-76.

BRANDÃO, M.; GAVILANES, M. L.; CUNHA, L.H.S.; LUCA-BUENDIA, J. P. ;CARDOSO, C. Plantas daninhas como fonte de nectar e pólen. In: CONGRESSO BRASILEIRO DE HERBICIDA E PLANTRA DANINHA, 15., Belo Horizonte, 1984. Resumos. Belo Horizonte, AUBERGRAF, 1984. p.9. 
BRANDÃO, M.; LUCA-BUENDIA, J. P.; GAVILANES, M.L.; ZURLO, M. A. ; CUNHA, L. H. S.; CARDOSO, C. Novos enfoque para plantas consideradas daninhas. Informe Agropecuário, Belo Horizonte, 129: 3-12, 1985.

BRANDI, R. M.; BARROS, N. F.; CANDIDO, J. F. Comparação de métodos de limpeza na formação de Eucalyptus alba (Blume) Reinw. E saligna e E brotyoides. Revista. Ceres, São Paulo, 21 (118): 427-33, 1974.

CARVALHO, E. F. de \& TORRES, L. G. Manejo de malas hierbas en sistemas agroforestales de Amazonia Agroforestería en las Américas Turrialba, 3 (jul-set) 6 - 9, 1994.

CHANCELLOR, R. J. Changes in the weed flora of an arable field cultivated for 20 years. Journal of Applied Ecology, London, 22: 491 - 502, 1985.

DANTAS, M. Ecossistemas de pastagens cultivadas; algumas alterações ecológicas. Belém, EMBRAPA/CPATU, $1980 . \quad 19$ p. (EMBRAPA/CPATU. Miscelâneal).

DANTAS, M. Studies on succession cleared areas of Amazonian rain forest, Oxford. 1989 395p. (PhD Oxford University).

DANTAS, M.; RODRIGUES, I. A. Plantas invasoras de pastagens cultivadas na Amazônia. Belém, EMBRAPA/CPATU, 1980. 23 p. (EMBRAPA/CPATU. Boletim de Pesquisa, 1).

DENICH, M. Estudo da importância de uma vegetação secundária nova para o incremento da produtividade do sistema de produção na Amazônia oriental brasileira. , 1989. (Doutorado - Universidade Georg August de Gottingen Alemanha. 1989). EMBRAPA/CPATU, Belém. 1991, 284 p. 
DERKSEN D. A.; LAFOND, G. P.; THOMAS, A. G.; LOEPPKY, H. A.; SWANTON, C. J. Impact of agronomic practices on weed communities: Tillage systems. Weed Science,Champaign,41 (3): 409-17, 1993.

DEUBER, R. Ciências das plantas daninhas; fundamentos. Jaboticabal, FUNEP, 1992. 431p.

DIAS FILHO, M. B. Plantas invasoras em pastagens cultivadas da Amazônia estratégias de manejo e controle. Belém, EMBRAPA-CPATU., 1990. 103 p. (EMBRAPA-CPATU. Documentos,52).

DIAS FILHO, M. B. \& SERRÃO, E. A .S. Limitações de fertilidade do solo na recuperação de pastagem degradada de capim colonião (Panicum maximum Jacq) em Paragominas, na Amazônia oriental. Belém, EMBRAPA-CPATU, 1987. 19p. (EMBRAPA-CPATU. Boletim de Pesquisa, 87)

DOMinGeS, E. P.; VElline, R. A.; PITElli, R. A.; PACHeCO, P. A. C. Efeito do matocompetição sobre a produtividade da cultura do arroz de sequeiro (Oryza sativa L.); em diferentes condições de espaçamento e de fertilização nitrogenada em cobertura. In: CONGRESSO BRASILEIRO DE HERBICIDA E PLANTAS DANINHAS, 6., Campinas, 1982. Resumos. Campinas, ALAM/SBHED, 1982. 33p.

FEARNSIDE, P. M. The effects of cattle pasture on soil fertility in the Brazilian Amazon: consequences for beef production sustainnability. Tropical Ecology, Allahabad, 21: 123-36, 1980.

FERNANDES, E. C. M.; NEVES, E. J. M.; MATOS, J. C. S. Agroflorestas, capoeiras manejadas e plantações florestais para reabilitação de áreas desmatdas na Amazônia Brasileira. In: CONGRESSO FLORESTAL PANAMERICANO, 1.; CONGRESSO FLORESTAL BRASILEIRO, 7., Curitiba, 1993. Anais. Curitiba, EMBRAPA-CNPF, 1994a. v.3, p. 
FERNANDES, E. C. M.; COOLMAN, R.; McKERROW A. J.; MATOS, J. S.; ARCOVERDE, M.; SOUSA, S. G. A.; PERIN, R. A. Dinâmica do solo, da vegetação e efeito ambientais sob sistemas agroflorestais em pastagens degradadas. Subprojeto de Pesquisa - 08.0.94.009-01. EMBRAPA/CPAA, Manaus, 1994b, $12 \mathrm{p}$.

FLORES, M. X.; QUIRINO, T. R.; NASCIMENTO, J. C.; RODRIGUES, G. S.; BUSCHINELLI, C. Pesquisa para agricultura auto-sustentável; perspectivas de políticas e organização na EMBRAPA. Brasilia, EMBRAPA/SEA, 1991. p. (EMBRAPA/SEA. Documentos, 5).

FORNARI, E. Pequeno manual de agricucltura alternativa. São Paulo, Sol Nascente, , 1983. 138p.

FREITAS, R. R. Dinâmica do banco de sementes em uma comunidade de plantas daninhas com aspectos da germinação e dormência de sementes de capimmarmelada (Brachiaria plantaginea (L.) Hitc. Lavras, 1990. 118 p. (Mestrado - Escola de Agricultura de Lavras).

FROUD-WILLIAMS, R. J.; CHANCELLOR, R. J.; DRENNAN, D. S. H. Influence of cultivation regime upon buried seeds in arable cropping systems. Journal of Applied Ecology, London, 20: 199-208, 1983.

GARCIA, M. A. Comunidades de plantas e artrópodes invasores em cultura de milho. Campinas, 1988. 272p. (Doutorado-UNICAMP).

GENTRY, A. H. Changes in plant community diversity and floristic composition on environmental and geographical gradients. Annals of Missouri Botanical Garden, New York, 75 (1): 1-34, 1988.

HARPER, J. L. Population biology of plants. London, Academic Press, 1977. 892p. 
IPEAAOc. Convênio para levantamento da área do Distrito Agropecuário da SUFRAMA, IPEAN e IPEAAOc. Solos do Distrito Agropecuário da SUFRAMA, Manaus, IPEAAOc, 1971, 99p.

KELLMAN, M. Geographic patteming in tropical weed communities and early secondary successions. Biotropica, Laurence, 12 (suppl.): 34-9, 1980.

KISSMANN, K. G. \& GROTH, D. Plantas infestantes e nocivas. São Paulo, BASF Brasileira S.A.., 1992. 798p. t2.

KLINGE, H.; RODRIGUES, W. A.; BRUNIG, E. F.; FITTKAU, E. J. Biomass and structure in a Central Amazonian rain forest. In: GOLLEY, F. F.; MEDINA, E. ed. Ecological studies; II Tropical Ecological Systems. New York, Springer-Verlag, 1975. p.115-22.

KLINGMAN, G. C. \& ASHTON, F. M. Weed science; principles and pratices. New York, John Wiley, 1975. 430p.

KOEPF, H. H.; PETERSON, B. D.; SCHAUMANN, W. Agricultura biodinâmica. 2.ed. São Paulo, Nobel, 1984. 316p.

LEITÃO FILHO, .; ARANHA, C.; BACCHI, O. Plantas invasoras de culturas no Estado de São Paulo. São Paulo, Hucitec, 1972. 2v.

LORENZI, H. Manual de identificação e controle de plantas daninhas: plantio direto e convencional. 2.ed. Nova Odessa, Plantarum, 1986. 440p.

LORENZI, H. Manual de identificação e controle de plantas daninhas: plantio direto e convencional. 4.ed. Nova Odessa, Plantarum, 1994. 299p.

LORENZI, H. Plantas daninhas da cultura do milho. Divulgação Agronômica Shell, São Paulo, (47): 1-9, 1980.

LORENZI, H. Plantas daninhas do Brasil: terrestres, aquáticas, parasitas, tóxicas e medicinais. 2.ed. Nova Odessa, Plantarum, 1991. 439p. 
LUIZÃO, K. C. C. \& LUIZÃO, F. J. Liteira e biomassa microbiana do solo no ciclo da matéria orgânica e nutrientes em terra firme na Amazônia central. In: VAL A. L.; FIGLIUOLO R. e FELDBERG E. Bases cientificas para estratégias de preservação e desenvolvimento da Amazônia: Fatos e perspectivas. Manaus, INPA 1991 p.65 - 75.

McKEEEOW, A. J. Nutrient stocks in adandoned pastures of the central Amazon Basis prior to and following cutting and burning. Raleigh, 1992. 116p. (MS - North Carolina State University).

MILLER, T. E. Community diversity and interactions between the size and frequency of disturbance. American Naturalist, Lancaster, 120: 533-36, 1982.

MURPHEY, J. \& RILEY, J. P. A modified single solutioun method for determination of phosphate in natural waters. Analytica Chemica Acta 27: $31-36,1962$.

NAIR, P. K. R. An introduction to Agrofloretry. Dordrecht, Kluwer, 1993. $499 p$.

ODUN, E. P. Ecologia. 3ed. Rio de Janeiro, Guanabara, 1988. 434p.

OLADOKUN, M. A. O. Weed control in agroforestry systems. In ICRAF ed. Report of a study carried out at the International Council for Research in Agroforestry-ICRAF, Nairobi, ICRAF, 1989, 25 p.

OOSTING, H. J. The study of plant communities. 2.ed. San Francisco, Freeman, 1956. 440p.

PALM, C. A. Mulch quality and nitrogen dynamics in an alley cropping system in the Peruvian Amazon. Raleigh, 1988. 120p. (PhD - North Caroline State University). 
PITELLI, R. A. Interferência de plantas daninhas em culturas agrícolas. Informe Agropecuário, Belo Horizonte, 129: 3-12, 1985.

PITELLI, R. A. \& DURIGAN, J. C. Terminologia para periodos de controle e de convivência das plantas daninhas em culturas anuais e bianuais. In : CONGRESSO BRASILEIRO DE HERBICIDAS E PLANTAS DANINHAS, 15., Belo Horizonte, 1984. Resumos. Piracicaba, AUGEGRAF, 1984. $27 \mathrm{p}$.

PITELLI, R. A. \& MARCHI, S. R. Interferência das plantas invasoras nas áreas de reflorestamento. In: SEMINARIO TECNICO SOBRE PLANTAS DANINHAS E USO DE HERBICIDAS EM REFLORESTAMENTO, 6., Belo Horizonte. Anais. Jaboticabal, FUNEP, 1991. 90p.

PLEASANT, J. M.; McCOLLUM, R. E.; COBLE, H. D. Weed population dynamics and weed control in the Peruvian Amazon. Agronomy Journal, Madison, 82(1): 102-12, 1990.

PLUCKNETT, D. L. \& SMITH, N. J. H. Historical perspectives on multiple cropping. In: FRANCIS, C., ed. Multiple cropping systems. New York Macmillan Pubp. 1986 p.20-39.

POWLSON, D. S. ; BROOKES, P. C. e CHRISTENSEN, B. T. Measurement of soil microbial biomass provides an early indication of change in total soil organic matter due to straw incorporation. Soil Biology Biochemical, 19 (2): 159-164, 1987.

PRIMAVESI, A. Agricultura sustentável, São Paulo, Nobel, 1992, $141 \mathrm{p}$.

PRIMAVESI, A Manejo ecologico de pastagens, São Paulo, Nobel, 1992, 95p.

REDFORD, K. H. ; KLEIN, B.; MURCIA, C . Incorporation of game animals into small-scale agroforestry systems in the Neotropics In: REDFORD, K.H.; PADOCH, C. ed Conservation of neotropics forests; working from 
traditional resource use. New York. Columbia University Press, 1992. p.333-358.

ROBERTS, H. A. Seed bank in soil. Advances in Applied Biology. New York, 6(1): 1-55, 1981.

ROBERTS, H. A. Studies on the weeds of vegetable crops III. Effect of different primary cultivations on the weed seeds in the soil. Journal of Ecology, Oxford, 1963 p.51: 83-95.

RODRIGUES, B. N. Controle biológico de plantas daninhas. Informe Agropecuário, Belo Horizonte, 129: 83-6, 1985.

SALOMON, M. E. Dinâmica de populações. São Paulo, EPU, 1980. 78p.

SANCHEZ, P. A. Properties and management of soils in the tropics. New York John Wiley, 1976. 618p.

SANCHEZ, P. A.\& BENÍTES, J. R. Cultivos de bajos insumos para suelos acidos de los tropicos humedos In: SMYTH T.J.; RAUN, W.R.; BERTSCH, F. ed. Manejo de suelos tropicales en latinoamerica. Raleigh, NCSU-Soil Science Dep, 1991 p.48-57.

SCHONINGH, E.; BURGER, D.; STOLBERG-WERNIGERODE, A. G. Z.; LENTHE, H. R. Efeito da cobertura morta em Latossolo Amarelo da Amazônia oriental. In: EMBRAPA/CPATU. Pesquisas sobre utilização e conservação do solo na Amazônia oriental Belém, 1986 p. 187-202 .(EMBRAPA/CPATU. Documento, 40).

SERRÃO, E. A. S. \& HOMMA, A. K. O. Agriculture in the Amazon; the question of sustainability In: Committee for agriculture sustainability and environment in the humid tropics. Washington, World Bank, 1991. 100p. 
SERRÃO, E. A. S.; FALESI, I. C.; VIEGAS, J. B. de; TEIXEIRA NETO, J.F. Productivity of Cultivated Pastures on Low Fertility Soils of Amazon Basis. In: SANCHEZ, P. A.; TERGAS, L. E., ed. Pasture production in acid soils of the tropics. Cali, CIAT. 1979 p.195 -225.

SILVA, M. F. da; LISBOA, P. L. B. e LISBOA, R. C. Nomes vulgares de plantas Amazônicas. Manaus, CNPq/INPA. 1977, 222p.

SOUSA, S. G. A.; VIANA, V.M.; FERNANDES, E.C.M. Ocorrência de plantas secundárias em sistemas agroflorestais na recuperação de pastagens degradadas na Amazônia ocidental. In: CONGRESSO BRASILEIRO SOBRE SISTEMAS AGROFLORESTAIS 1. Porto Velho, Anais. Colombo, EMBRAPA-CNPF, 1994 p.475.

UHL, C.; BUSCHBACHER, R.; SERRÃO, E. A. S. Abandoned pastures in Eastern Amazonia. I. Patterns of plant succession. Journal of Ecology Oxford, 76: 663-81, 1988.

UHL, C.; NEPSTAD, D.; BUSCHBACHER, R.; CLARK, K.; KAUFFMAN, B.; SUBLER S. Studies in ecosystem response to natural and anthropogenic disturbances provide guidelines for designing sustainable land-use systems in Amazonia. In: ANDERSON, A., ed. Alternatives to deforestation. New York, Columbia Univ. Press, 1990, p.24-42.

KAGEYAMA, P. Y. \& VIANA, V. M. Tecnologia de sementes e grupos ecológicos de espécies arbóreas tropicais. In: Simpósio brasileiro sobre tecnologia de sementes florestais 2, São Paulo Anais São Paulo, Instituto Florestal, 1989, p. p.1-19

VIANA, V. M. Ecologia de populações florestais colonizadoras e recuperação de áreas degradadas. In: Simpósio sobre ecossistemas da costa sul e sudeste brasileira. São Paulo, Academia de Ciências do Estado de São de Paulo, 54 (1) 1987, p.29 - 39 . 
VIANA V. M.\& SIQUEIRA E. Sistemas agroflorestais para o programa hortos florestais do Estado do Espirito Santo. In: Seminário sobre Alternativas Econômicas, Linhares, 1992 Anais. Vitoria, BNDS/ESR 1-10p.

VICTORIA FILHO, R. Manejo integrado de plantas daninhas em pastagens In: SIMPÓSIO INTERNACIONAL DE MANEJO INTEGRADO DE PRAGAS, DOEÇAS E PLANTAS DANINHAS 1. Campinas, 1988, Anais, Campinas, CATI, 1988 p.189-197.

WALKER, R. H. \& BUCHANAN, G. A. Crop manipulation in integrated weed management systems, Weed Science, Champaighn, 30 (suppl.): 17-24, 1982.

WILLLIAMS, E. D. Changes during 3 years in the size and composition of the seed bank beneath a long-term pasture as influenced by defoliation and fertilizer regime. Journal of Applied Ecology, London, 21: 603-15, 1984.

YORINORI, J.T. Controle Biológico de ervas daninhas. In: REUNIÃO ANUAL SOBRE CONTROLE BIÓLOGICO DE DOENÇAS E PLANTAS, II, Piracicaba, 1987, Anais. Piracicaba, 1987. p.20-29.

ZEN. S. Influência da mato competição em plantas de Eucalyptus gradis In: SEMINARIO SOBRE HERBICIDAS EM REFLORESTAMENTO, Piracicaba, 1986. Série Técnica IPEF 4 (12): 25-35, 1987.

ZINDAHL, R. L. Weed-crop competition - a review. Corvallis, Oregon State University, 1980, $195 \mathrm{p}$. 
APÊNDICE 
Tabela 1 - Lista da presença das espécies nos sistemas e pastagem.

\begin{tabular}{|c|c|c|c|c|c|c|}
\hline FAMílIA & GÊNERO E ESPĖCIE & SAF1 & SAF2 & SAF3 & SAF4 & PA \\
\hline ASTERACEAE & Acanthospermum australe & - & $\mathrm{X}$ & - & - & \\
\hline ASTERACEAE & Ageratum conyzoides & $\bar{X}$ & - & - & $\bar{X}$ & \\
\hline AMARANTACEAE & Alternanthera ficoidea & $\mathrm{X}$ & - & - & $\bar{X}$ & \\
\hline RUBIACEAE & Borreria alata & $\mathrm{X}$ & $\mathrm{X}$ & $\mathrm{X}$ & $\mathrm{X}$ & \\
\hline RUBIACEAE & Borreria latifolia & $\bar{X}$ & $\bar{X}$ & $\bar{X}$ & $\bar{X}$ & $\bar{X}$ \\
\hline RUBIACEAE & Borreria verticillata & $\bar{X}$ & $\bar{X}$ & $\bar{X}$ & $\bar{X}$ & $\bar{X}$ \\
\hline POACEAE & Brachiaria humidicola & $\mathrm{X}$ & $\mathrm{X}$ & $\mathrm{X}$ & $\mathrm{X}$ & $\mathrm{X}$ \\
\hline POACEAE & Brachiaria plantaginea & $\bar{X}$ & $\bar{X}$ & $\bar{X}$ & $\bar{X}$ & \\
\hline POACEAE & Brachiaria sp & - & $\mathrm{X}$ & - & - & \\
\hline FABACEAE & Calopogonio muconoides & $\bar{X}$ & $\mathrm{X}$ & $\mathrm{X}$ & $\mathrm{X}$ & \\
\hline POACEAE & Capim (sp 1) & $\bar{X}$ & $\bar{X}$ & & $\bar{X}$ & \\
\hline CECROPIACEAE & Cecropia sp & - & - & $\bar{X}$ & - & \\
\hline MELASTOMATACEAE & Clidemia hirta & - & - & $\bar{X}$ & - & \\
\hline COMMELINACEAE & Commelina benghalensis & - & - & - & $\bar{X}$ & \\
\hline COMMELINACEAE & Commelina sp & - & $\mathrm{X}$ & - & $\mathrm{X}$ & \\
\hline ASTERACEAE & Compositae/Asteraceae (sp 4) & - & - & - & $\bar{X}$ & \\
\hline EUPHORBIACEAE & Crotum lobatus & $\bar{X}$ & & $\bar{X}$ & $\bar{X}$ & \\
\hline CYPERACEAE & Cyperus diffusus & $\bar{X}$ & $\mathrm{X}$ & $\bar{X}$ & $\mathrm{X}$ & \\
\hline CYPERACEAE & Cyperus distans & $\bar{X}$ & $\mathrm{X}$ & $\mathrm{X}$ & $\mathrm{X}$ & \\
\hline CYPERACEAE & Cyperus sp & $\bar{X}$ & $\bar{X}$ & - & $\bar{X}$ & \\
\hline FABACEAE & Dalbergia $s p$ & $\mathrm{X}$ & $\mathrm{X}$ & - & - & $\bar{X}$ \\
\hline CYPERACEAE & Dichromena ciliata & $\bar{X}$ & $\bar{X}$ & $\bar{X}$ & $\mathrm{X}$ & \\
\hline POACEAE & Digitaria insulares & $\mathrm{X}$ & - & - & - & \\
\hline POACEAE & Digitaria sanguinallis & - & - & - & $\bar{X}$ & \\
\hline POACEAE & Digitaria $s p$ & $\bar{X}$ & $\bar{X}$ & $\bar{X}$ & $\bar{X}$ & \\
\hline POACEAE & Digitaria (sp. 2) & $\mathrm{X}$ & $\bar{X}$ & $\bar{X}$ & - & \\
\hline POACEAE & Eleusine indica & $\mathrm{X}$ & $\mathrm{X}$ & - & $\bar{X}$ & \\
\hline |ASTERACEAE & Emilia sagitatta & $\bar{X}$ & $\bar{X}$ & - & - & \\
\hline ASTERACEAE & Emilia sanchifolia & $\mathrm{X}$ & $\mathrm{X}$ & - & - & \\
\hline POACEAE & Eragrostis sp & $\mathrm{X}$ & $\bar{X}$ & - & - & \\
\hline ASTERACEAE & Erigeron bonariensis & $\mathrm{X}$ & $\mathrm{X}$ & - & $X$ & \\
\hline |EUPHORBIACEAE & Euphorbia hyssopifolia & $\mathrm{X}$ & - & - & $\mathrm{X}$ & \\
\hline EUPHORBIACEAE & Euphorbia pilulifera & - & - & - & $\bar{X}$ & \\
\hline EUPHORBIACEAE & Euphorbia prostrata & $\bar{X}$ & - & - & $\bar{X}$ & \\
\hline CYPERACEAE & Fimbristylis annua . & $\mathrm{X}$ & $\mathrm{X}$ & $X$ & $\mathrm{X}$ & $\bar{X}$ \\
\hline CYPERACEAE & Fimbristylis $s p$ & $\bar{X}$ & $\mathrm{X}$ & $\mathrm{X}$ & $\mathrm{X}$ & \\
\hline POACEAE & Homolepis aturensis & $\bar{X}$ & $\mathrm{X}$ & $\mathrm{X}$ & $\mathrm{X}$ & $\bar{X}$ \\
\hline VERBENACEAE & Lantana camara & $\mathrm{X}$ & $X$ & - & $\mathrm{X}$ & $\bar{X}$ \\
\hline MIMOSACEAE & Mimosa pudica & $\bar{X}$ & - & - & $\bar{X}$ & $\bar{X}$ \\
\hline MIRTACEAE & Mirtaceae (sp 3) & $\bar{X}$ & - & - & - & \\
\hline ASTERACEAE & |Orthopappus angustifolius & - & - & - & $\bar{X}$ & \\
\hline POACEAE & Paspalum conjugatum & $\mathrm{X}$ & $\mathrm{X}$ & $\mathrm{X}$ & $\mathrm{X}$ & \\
\hline POACEAE & Paspalum multicaule & $\bar{X}$ & $\bar{X}$ & $\bar{X}$ & $\mathrm{X}$ & \\
\hline POACEAE & Paspalum sp & $\mathrm{X}$ & $\mathrm{X}$ & $\mathrm{X}$ & $\mathrm{X}$ & \\
\hline POACEAE & Paspalum virgatum & - & - & - & $\bar{X}$ & \\
\hline SOLANACEAE & Physalis angulata & $\bar{X}$ & - & - & $\bar{X}$ & \\
\hline SOLANACEAE & Physalis pubescentes & - & - & - & $\mathrm{X}$ & \\
\hline
\end{tabular}




\begin{tabular}{|l|l|c|c|c|c|c|}
\hline \multicolumn{1}{|c|}{ FAMILIA } & \multicolumn{1}{|c|}{ GËNERO E ESPECIES } & SAF1 & SAF2 & SAF3 & SAF4 & PA \\
\hline EUPHORBIACEAE & Phyllanthus niruri & - & - & - & $\mathrm{X}$ & \\
\hline PIPERACEAE & Piper aducam & $\mathrm{X}$ & - & $\mathrm{X}$ & - & \\
\hline IASTERACEAE & Rolandra fruticosa & $\mathrm{X}$ & $\mathrm{X}$ & $\mathrm{X}$ & $\mathrm{X}$ & $\mathrm{X}$ \\
\hline CYPERACEAE & Scleria secans & - & $\mathrm{X}$ & - & - & $\mathrm{X}$ \\
\hline POACEAE & Setaria verticillata & - & $\mathrm{X}$ & $\mathrm{X}$ & - & \\
\hline MALVACEAE & Sida glaziovii & $\mathrm{X}$ & - & - & - & \\
\hline MALVACEAE & Sida rhombifolia & $\mathrm{X}$ & $\mathrm{X}$ & $\mathrm{X}$ & $\mathrm{X}$ & $\mathrm{X}$ \\
\hline SOLANACEAE & Solanum grandiflorum & $\mathrm{X}$ & - & $\mathrm{X}$ & - & $\mathrm{X}$ \\
\hline SOLANACEAE & Solanum juripeba & $\mathrm{X}$ & $\mathrm{X}$ & $\mathrm{X}$ & $\mathrm{X}$ & $\mathrm{X}$ \\
\hline SOLANACEAE & Solanum rugosum & $\mathrm{X}$ & $\mathrm{X}$ & $\mathrm{X}$ & $\mathrm{X}$ & $\mathrm{X}$ \\
\hline POACEAE & Sorghum halepense & $\mathrm{X}$ & - & - & $\mathrm{X}$ & \\
\hline VERBENACEAE & Stachytarpheta caynnensis & $\mathrm{X}$ & $\mathrm{X}$ & $\mathrm{X}$ & $\mathrm{X}$ & $\mathrm{X}$ \\
\hline BIGNONIACEAE & Tabebuia sp & - & - & $\mathrm{X}$ & - & \\
\hline CLUSIACEAE & Vismia cayennensis & - & $\mathrm{X}$ & - & - & $\mathrm{X}$ \\
\hline CLUSIACEAE & Vismia sp & $\mathrm{X}$ & - & - & $\mathrm{X}$ & $\mathrm{X}$ \\
\hline FABACEAE & Legurninosa/Fabaceae (sp 5) & $\mathrm{X}$ & - & - & - & \\
\hline FALCOURTIACEAE & Laetia procera & - & - & - & - & $\mathrm{X}$ \\
\hline
\end{tabular}


Tabela 2 - Lista de presença das espécies nos períodos.

\begin{tabular}{|c|c|c|c|c|c|c|}
\hline FAMILIA & GËNERO E ESPĖCIE & P1 & P2 & P3 & P4 & P5 \\
\hline ASTERACEAE & Acanthospermum australe & - & - & $\mathrm{X}$ & $\mathrm{X}$ & $\mathrm{X}$ \\
\hline ASTERACEAE & Ageratum conyzoides & - & - & $\mathrm{X}$ & - & $\bar{X}$ \\
\hline AMARANTACEAE & Alternanthera ficoidea & - & $\mathrm{X}$ & $\mathrm{X}$ & $\mathrm{X}$ & $\mathrm{X}$ \\
\hline RUBIACEAE & Borreria alata & - & $\mathrm{X}$ & $\mathrm{X}$ & $\mathrm{X}$ & $\bar{X}$ \\
\hline RUBIACEAE & Borreria latifolia & $\bar{X}$ & $\mathrm{X}$ & $\mathrm{X}$ & $\mathrm{X}$ & $\bar{X}$ \\
\hline RUBIACEAE & Borreria verticillata & $\bar{X}$ & $\bar{X}$ & $\mathrm{X}$ & $\mathrm{X}$ & $\mathrm{X}$ \\
\hline POACEAE & Brachiaria humidicola & $\mathrm{X}$ & $\bar{X}$ & $\mathrm{X}$ & $\mathrm{X}$ & $\bar{X}$ \\
\hline POACEAE & Brachiaria plantaginea & $\bar{X}$ & $\mathrm{X}$ & $\mathrm{X}$ & $X$ & $\bar{X}$ \\
\hline POACEAE & Brachiaria $s p$ & $\mathrm{X}$ & - & - & - & - \\
\hline FABACEAE & Calopogonio muconoides & $\mathrm{X}$ & $\bar{X}$ & $\bar{X}$ & $\bar{X}$ & $\bar{X}$ \\
\hline POACEAE & Capim (sp 1) & - & - & $\mathrm{X}$ & - & $\bar{X}$ \\
\hline CECROPIACEAE & Cecropia sp & $\bar{X}$ & - & - & - & - \\
\hline MELASTOMATACEAE & Clidemia hirta & - & - & - & - & $\bar{X}$ \\
\hline COMMELINACEAE & Commelina benghalensis & $\mathrm{X}$ & $\mathrm{X}$ & - & $\mathrm{X}$ & - \\
\hline COMMELINACEAE & |Commelina sp & - & $\mathrm{X}$ & $\mathrm{X}$ & $\mathrm{X}$ & $\mathrm{X}$ \\
\hline ASTERACEAE & |Compositae/Asteraceae (sp 4) & - & - & - & - & $\bar{X}$ \\
\hline EUPHORBIACEAE & Crotum lobatus $L$. & - & - & - & $\bar{X}$ & $\mathrm{X}$ \\
\hline CYPERACEAE & Cyperus diffusus & - & - & $\bar{X}$ & $\bar{X}$ & $\mathrm{X}$ \\
\hline CYPERACEAE & Cyperus distans & - & $\mathrm{X}$ & $\mathrm{X}$ & $\mathrm{X}$ & $\mathrm{X}$ \\
\hline CYPERACEAE & Cyperus sp & - & - & - & - & $\mathrm{X}$ \\
\hline FABACEAE & Dalbergia $s p$ & - & - & $\bar{X}$ & - & $\bar{X}$ \\
\hline CYPERACEAE & Dichromena ciliata & - & $\mathrm{X}$ & - & $\mathrm{X}$ & $\bar{X}$ \\
\hline POACEAE & Digitaria insulares & - & - & $\bar{X}$ & - & - \\
\hline POACEAE & Digitaria sanguinallis & - & - & $\bar{X}$ & - & - \\
\hline POACEAE & Digitaria $s p$ & $\mathrm{X}$ & $\bar{X}$ & $\mathrm{X}$ & $\bar{X}$ & $\bar{X}$ \\
\hline POACEAE & Digitaria (sp 2) & $\mathrm{X}$ & $\bar{X}$ & $\mathrm{X}$ & $\bar{X}$ & $\bar{X}$ \\
\hline POACEAE & Eleusine indica & $\mathrm{X}$ & - & $\bar{X}$ & $\bar{X}$ & - \\
\hline ASTERACEAE & Emilia sagitatta & - & $\mathrm{X}$ & $\bar{X}$ & - & $\bar{X}$ \\
\hline ASTERACEAE & Emilia sanchifolia & $\mathrm{X}$ & $\mathrm{X}$ & $\bar{X}$ & $\bar{X}$ & $\bar{X}$ \\
\hline POACEAE & Eragrostis sp & - & - & - & - & $\bar{X}$ \\
\hline ASTERACEAE & Erigeron bonariensis & $\mathrm{X}$ & $\mathrm{X}$ & $\mathrm{X}$ & $\mathrm{X}$ & - \\
\hline EUPHORBIACEAE & |Euphorbia hyssopifolia & - & - & - & $\mathrm{X}$ & $\mathrm{X}$ \\
\hline EUPHORBIACEAE & Euphorbia pilulifera & - & $\bar{X}$ & - & $\mathrm{X}$ & - \\
\hline EUPHORBIACEAE & Euphorbia prostrata & - & $\bar{X}$ & - & $\mathrm{X}$ & $\bar{x}$ \\
\hline CYPERACEAE & Fimbristylis annua & $\mathrm{X}$ & $\mathrm{X}$ & $\mathrm{X}$ & $\mathrm{X}$ & $\mathrm{X}$ \\
\hline CYPERACEAE & Fimbristylis sp & - & - & - & - & $\bar{X}$ \\
\hline POACEAE & Homolepis aturensis & - & $\bar{X}$ & $\mathrm{X}$ & $\bar{X}$ & $\bar{X}$ \\
\hline VERBENACEAE & Lantana camara & - & $\mathrm{X}$ & - & $\mathrm{X}$ & $\mathrm{X}$ \\
\hline MIMOSACEAE & Mimosa pudica & - & - & $\mathrm{X}$ & - & $\mathrm{X}$ \\
\hline MIRTACEAE & Mirtaceae (sp 3) & - & - & - & - & $\mathrm{X}$ \\
\hline ASTERACEAE & Orthopappus angustifolius & - & - & - & - & $\mathrm{X}$ \\
\hline POACEAE & Paspalum conjugatum & $\mathrm{X}$ & $\mathrm{X}$ & $\mathrm{X}$ & $\mathrm{X}$ & $\mathrm{X}$ \\
\hline POACEAE & Paspalum multicaule & $\mathrm{X}$ & $\mathrm{X}$ & $\mathrm{X}$ & $\mathrm{X}$ & $\mathrm{X}$ \\
\hline POACEAE & Paspalum sp & $X$ & $\mathrm{X}$ & $X$ & $\mathrm{X}$ & $\mathrm{X}$ \\
\hline POACEAE & Paspalum virgatum & - & $\bar{X}$ & - & $\mathrm{X}$ & $\mathrm{X}$ \\
\hline SOLANACEAE & Physalis angulata & $\mathrm{X}$ & $\bar{X}$ & $\bar{X}$ & $\mathrm{X}$ & - \\
\hline SOLANACEAE & Physalis pubescentes & - & $\mathrm{X}$ & $\mathrm{X}$ & $\mathrm{X}$ & - \\
\hline
\end{tabular}




\begin{tabular}{|l|l|c|c|c|c|c|}
\hline FAMIIIA & GËNERO E ESPÉCIES & $\mathrm{P} 1$ & $\mathrm{P} 2$ & $\mathrm{P} 3$ & $\mathrm{P} 4$ & $\mathrm{P} 5$ \\
\hline EUPHORBIACEAE & Phyllanthus niruri & - & - & - & - & $\mathrm{X}$ \\
\hline PIPERACEAE & Piper aducam & - & - & - & $\mathrm{X}$ & $\mathrm{X}$ \\
\hline ASTERACEAE & Rolandra fruticosa & $\mathrm{X}$ & $\mathrm{X}$ & $\mathrm{X}$ & $\mathrm{X}$ & $\mathrm{X}$ \\
\hline CYPERACEAE & Scleria secans & $\mathrm{X}$ & - & - & - & - \\
\hline POACEAE & Setaria verticillata & - & $\mathrm{X}$ & $\mathrm{X}$ & $\mathrm{X}$ & - \\
\hline MALVACEAE & Sida glaziovii & - & $\mathrm{X}$ & - & - & - \\
\hline MALVACEAE & Sida rhombifolia & $\mathrm{X}$ & $\mathrm{X}$ & $\mathrm{X}$ & $\mathrm{X}$ & $\mathrm{X}$ \\
\hline SOLANACEAE & Solanum grandiflorum & $\mathrm{X}$ & - & - & - & - \\
\hline SOLANACEAE & Solanum juripeba & $\mathrm{X}$ & $\mathrm{X}$ & $\mathrm{X}$ & $\mathrm{X}$ & $\mathrm{X}$ \\
\hline SOLANACEAE & Solanum rugosum & $\mathrm{X}$ & $\mathrm{X}$ & $\mathrm{X}$ & $\mathrm{X}$ & $\mathrm{X}$ \\
\hline POACEAE & Sorghum halepense & $\mathrm{X}$ & $\mathrm{X}$ & $\mathrm{X}$ & $\mathrm{X}$ & - \\
\hline VERBENACEAE & Stachytarpheta caynnensis & $\mathrm{X}$ & $\mathrm{X}$ & $\mathrm{X}$ & $\mathrm{X}$ & $\mathrm{X}$ \\
\hline BIGNONIACEAE & Tabebuia sp & - & $\mathrm{X}$ & $\mathrm{X}$ & - & $\mathrm{X}$ \\
\hline CLUSIACEAE & Vismia cayennensis & $\mathrm{X}$ & $\mathrm{X}$ & - & - & - \\
\hline CLUSIACEAE & Vismia sp & - & $\mathrm{X}$ & - & - & $\mathrm{X}$ \\
\hline FABACEAE & Leguminosa/Fabaceae (sp 5) & - & - & - & $\mathrm{X}$ & - \\
\hline
\end{tabular}


Tabela 3 - Índice de Valor de Importância (\%) das espécies no SAF1 por período.

\begin{tabular}{|c|c|c|c|c|c|c|}
\hline & \multicolumn{5}{|c|}{ PERÍODO } & \multirow[b]{2}{*}{ TOTAL } \\
\hline ESPECIES & 1 & 2 & 3 & 4 & 5 & \\
\hline Fimbristylis annua & 31.82 & 31.66 & 20.91 & 20.30 & 14.07 & 23.75 \\
\hline Solanum juripeba & 20.56 & 19.82 & 24.57 & 9.40 & 11.42 & 17.15 \\
\hline Brachiaria humidicola & 3.45 & 14.14 & 16.88 & 18.11 & 16.11 & 13.74 \\
\hline Borreria verticillata & 13.23 & 8.85 & 10.03 & 6.98 & 5.90 & 9.00 \\
\hline Paspalum coniugatum & 8.32 & 6.36 & 4.93 & 4.38 & 12.25 & 7.25 \\
\hline Paspalum $s p$ & - & 3.63 & 7.94 & 13.49 & 6.25 & 6.26 \\
\hline H. aturensis & - & 1.02 & 3.52 & 6.81 & 12.20 & 4.71 \\
\hline Digitaria $s p$ & 2.49 & 0.74 & - & 6.56 & 7.30 & 3.42 \\
\hline S. cayennensis & 4.55 & 4.10 & 1.79 & 2.02 & 1.37 & 2.76 \\
\hline Solanum rugosum & 3.87 & 1.42 & 1.24 & 1.95 & 0.21 & 1.74 \\
\hline Digitaria (sp 2) & 0.87 & - & - & 1.12 & 3.41 & 1.08 \\
\hline Rolandra fruticosa & 1.94 & 1.86 & 0.35 & 0.48 & 0.58 & 1.04 \\
\hline Paspalum multicaule & - & 0.84 & 0.93 & 0.24 & 2.92 & 0.99 \\
\hline Sida rhombifolia & - & 2.00 & 1.25 & 0.67 & - & 0.78 \\
\hline Emilia sanchifolia & 1.39 & 0.97 . & - & 0.26 & 0.90 & 0.71 \\
\hline Brachiaria plantaginea & - & - & 1.70 & 0.83 & 0.25 & 0.55 \\
\hline Eleusine indica & 2.59 & - & - & - & - & 0.52 \\
\hline Solanum rugosum & 1.05 & - & - & 1.41 & - & 0.49 \\
\hline Physalis pubescentes & 1.07 & 0.73 & 0.61 & - & - & 0.48 \\
\hline Borreria latifolia & 2.29 & - & - & - & - & 0.46 \\
\hline Fimbristylis $s p$ & - & - & - & - & 2.05 & 0.41 \\
\hline Digitaria insulares & - & - & 1.28 & - & - & 0.26 \\
\hline Borreria alata & - & - & 0.38 & 0.85 & - & 0.25 \\
\hline Emilia sagitatta & - & 0.63 & 0.44 & - & - & 0.22 \\
\hline Erigeron bonariensis & - & - & 0.32 & 0.70 & - & 0.20 \\
\hline Dichromena ciliata & - & 0.63 & - & 0.21 & - & 0.17 \\
\hline Euphorbia prostrata & - & - & - & 0.68 & - & 0.14 \\
\hline Eragrostis sp & - & - & - & - & 0.62 & 0.12 \\
\hline Alternanthera ficoidea & - & - & - & - & 0.55 & 0.11 \\
\hline Agerantum conyzoides & - & - & 0.54 & - & - & 0.11 \\
\hline Cyperus distans & - & - & - & 0.53 & - & 0.11 \\
\hline C. muconoides & - & - & - & 0.52 & - & 0.10 \\
\hline Solanum grandiflorum & 0.49 & - & - & - & - & 0.10 \\
\hline Crotum lobatum & - & - & - & 0.47 & 0.00 & 0.10 \\
\hline Capim (sp 1) & - & - & - & - & 0.41 & 0.08 \\
\hline Cyperus diffusus & - & - & 0.40 & - & - & 0.08 \\
\hline Piper aducam & - & - & - & 0.19 & 0.21 & 0.08 \\
\hline Lantana camara & - & - & - & 0.37 & - & 0.07 \\
\hline Mimosa pudica & - & - & - & - & 0.36 & 0.07 \\
\hline Sida glaziovi & - & 0.30 & - & - & - & 0.06 \\
\hline Vismia $s p$ & - & 0.29 & - & - & - & 0.06 \\
\hline Cyperus sp & - & - & - & 0.06 & 0.21 & 0.05 \\
\hline Mirtaceae $(\mathrm{sp} 3)$ & - & - & - & - & 0.24 & 0.05 \\
\hline Euphorbia hvssopifolia & - & - & - & 0.23 & - & 0.05 \\
\hline Dalbergia $s p$ & - & - & - & - & 0.21 & 0.04 \\
\hline Fabaceae (sp 5) & - & - & - & 0.20 & - & 0.04 \\
\hline
\end{tabular}


Tabela 4 - Índice de Valor de Importância das espécies no SAF2 por período.

\begin{tabular}{|c|c|c|c|c|c|c|}
\hline & \multicolumn{5}{|c|}{ PERÍODO } & \\
\hline ESPECIES & 1 & 2 & 3 & 4 & 5 & TOTAL \\
\hline Paspalum multicaule & 16.92 & 32.61 & 34.43 & 17.87 & 5.20 & 21.41 \\
\hline Solanum juripeba & 26.73 & 18.66 & 13.71 & 5.34 & 6.30 & $\overline{14.15}$ \\
\hline Fimbristvlis annua & 16.58 & 15.13 & 10.73 & 15.60 & 7.24 & 13.05 \\
\hline Brachiaria humidicola & 5.71 & 10.17 & 8.33 & 11.67 & $\overline{12.44}$ & 9.66 \\
\hline Paspalum $s p$ & 6.74 & 0.31 & 4.86 & 17.65 & 8.42 & 7.59 \\
\hline Paspalum conjugatum & 7.27 & 3.58 & 5.76 & 3.98 & 14.19 & 6.96 \\
\hline Capim (spl) & - & - & 0.48 & 0.47 & 15.09 & 3.21 \\
\hline Borreria verticillata & 0.82 & 4.07 & 5.47 & 3.17 & 1.92 & 3.09 \\
\hline Brachiaria plantaginea & 1.81 & 2.40 & 0.98 & 3.54 & 3.35 & 2.42 \\
\hline Commelina $s p$ & - & 0.32 & 1.91 & 4.03 & 5.78 & 2.41 \\
\hline Digitaria $s p$ & 0.57 & 0.67 & 0.91 & 4.52 & 3.34 & 2.00 \\
\hline Lantana camara & 2.48 & 0.52 & 2.60 & 1.16 & 3.12 & 1.98 \\
\hline S. cavennensis & 5.20 & 0.96 & 0.96 & 0.72 & 2.04 & 1.98 \\
\hline Solanum rugosum & 3.92 & 2.38 & 2.10 & 0.47 & 0.27 & 1.83 \\
\hline Rolandra fruticosa & - & 3.54 & 0.60 & 0.44 & 0.71 & 1.06 \\
\hline Sorghum halepense & - & 0.30 & 3.00 & 1.32 & - & 0.92 \\
\hline Brachiaria sp & 1.20 & 1.30 & 0.34 & 1.06 & - & 0.78 \\
\hline H. aturensis & - & 0.66 & 0.21 & 1.20 & 1.78 & 0.77 \\
\hline Emilia sagitatta & - & - & - & - & 2.94 & 0.59 \\
\hline Vismia cavennensis & 1.81 & 0.31 & - & - & - & 0.42 \\
\hline Eragrostis $s p$ & - & 0.62 & - & - & 1.42 & 0.41 \\
\hline Cyperus distans & - & - & - & 1.47 & 0.38 & 0.37 \\
\hline Borreria latifolia & - & 0.43 & 0.41 & 0.27 & 0.66 & 0.36 \\
\hline Digitaria (sp 2) & 0.74 & 0.71 & - & 0.21 & - & 0.33 \\
\hline Sida rhombifolia & - & - & - & 0.59 & 0.88 & 0.29 \\
\hline Eleusine indica & 0.80 & - & 0.37 & 0.25 & - & 0.28 \\
\hline A. australe & - & - & 0.52 & 0.52 & 0.22 & 0.25 \\
\hline Cvperus diffusus & - & - & 0.38 & 0.63 & - & 0.20 \\
\hline Setaria verticillata & - & - & 0.32 & 0.64 & - & 0.19 \\
\hline Dichromena ciliata & - & - & - & - & 0.83 & 0.17 \\
\hline Scleria secans & 0.75 & - & - & - & - & 0.15 \\
\hline Borreria alata & - & 0.35 & - & 0.38 & - & 0.15 \\
\hline Emilia sanchifolia & - & - & 0.28 & - & 0.38 & 0.13 \\
\hline Erigeron bonariensis & - & - & - & 0.58 & - & 0.12 \\
\hline Fimbristvlis $S D$ & - & - & - & - & 0.44 & 0.09 \\
\hline Cvperus sp & - & - & - & - & 0.39 & 0.08 \\
\hline Dalbergia $s p$ & - & - & 0.35 & - & - & 0.07 \\
\hline Ageratum conyzoides & - & - & - & - & 0.28 & 0.06 \\
\hline C. muconoides & - & - & - & 0.26 & - & 0.05 \\
\hline
\end{tabular}


Tabela 5 - Índice de Valor de Importância das espécies no SAF3 por período.

\begin{tabular}{|c|c|c|c|c|c|c|}
\hline & \multicolumn{5}{|c|}{ PERIODO } & \multirow[b]{2}{*}{ TOTAL } \\
\hline ESPÉCIES & 1 & 2 & 3 & 4 & 5 & \\
\hline Fimbristylis annua & 14.43 & 31.41 & 13.15 & 18.58 & 23.10 & 20.14 \\
\hline Solanum juripeba & 26.30 & 16.88 & 18.99 & 10.32 & 16.03 & 17.70 \\
\hline Paspalum mu!ticaule & 25.49 & 14.22 & 28.87 & 11.36 & 4.04 & 16.80 \\
\hline Paspalum sp & - & 4.12 & 10.93 & 16.59 & 8.68 & 8.06 \\
\hline Borreria verticillata & 12.80 & 5.91 & 7.27 & 6.82 & 5.62 & 7.68 \\
\hline Brachiaria humidicola & 3.10 & 3.25 & 8.07 & 13.14 & 5.31 & 6.57 \\
\hline Sida rhombifolia & 3.18 & 2.78 & 3.30 & 6.21 & 3.59 & 3.81 \\
\hline Paspalum conjugatum & 5.13 & 7.51 & 2.58 & 0.55 & 2.80 & 3.71 \\
\hline H. aturensis & - & - & - & 4.07 & 11.07 & 3.03 \\
\hline Digitaria (sp 2) & - & 0.33 & 0.67 & 0.26 & 10.16 & 2.28 \\
\hline S. cavennensis & 1.86 & 2.20 & 2.46 & 2.07 & 0.51 & 1.82 \\
\hline Digitaria $s p$ & - & 3.01 & - & 3.49 & 2.18 & 1.74 \\
\hline Rolandra fruticosa & 1.81 & 2.36 & 1.09 & 2.40 & - & 1.53 \\
\hline Solanum rugosum & 2.21 & 2.27 & - & 1.24 & 0.72 & 1.29 \\
\hline Borreria latifolia & 2.30 & 0.77 & 0.44 & 0.27 & 0.50 & 0.86 \\
\hline Brachiaria plantaginea & - & - & 0.53 & 0.45 & 1.78 & 0.55 \\
\hline Tabebuia $s p$ & - & 0.93 & 0.70 & - & 1.10 & 0.55 \\
\hline Piper aducam & - & - & - & 0.40 & 0.74 & 0.23 \\
\hline Cyperus diffusus & - & - & - & 0.29 & 0.84 & 0.23 \\
\hline Cyperus distans & - & 0.59 & 0.47 & - & - & 0.21 \\
\hline Dichromena ciliata & - & 0.99 & - & - & - & 0.20 \\
\hline Crotum lobatum & - & - & - & 0.90 & - & 0.18 \\
\hline Borreria alata & - & - & 0.50 & - & 0.34 & 0.17 \\
\hline Setaria verticillata & - & 0.46 & - & 0.31 & - & 0.15 \\
\hline Solanum grandiflorum & 0.77 & - & - & - & - & 0.15 \\
\hline Cecropia sp & 0.63 & - & - & - & - & 0.13 \\
\hline Fimbristylis $s p$ & - & - & - & - & 0.35 & 0.07 \\
\hline Clidemia hirta & - & - & - & - & 0.34 & 0.07 \\
\hline C. muconoides & - & - & - & 0.27 & - & 0.05 \\
\hline
\end{tabular}


Tabela 6 - Índice de Valor de Importância das espécies no SAF4 por período.

\begin{tabular}{|c|c|c|c|c|c|c|}
\hline & \multicolumn{5}{|c|}{ PERÍODO } & \multirow[b]{2}{*}{ TOTAL } \\
\hline ESPECIES & 1 & 2 & 3 & 4 & 5 & \\
\hline Fimbristylis annua & 29.43 & 23.29 & 28.07 & 19.07 & 11.85 & 22.34 \\
\hline Paspalum conjugatum & 4.19 & 7.66 & 7.06 & 21.95 & 34.82 & 15.14 \\
\hline Brachiaria humidicola & 12.55 & 11.22 & 32.69 & 6.69 & 2.21 & 13.07 \\
\hline Borreria verticillata & 18.25 & 10.49 & 14.46 & 7.85 & 5.35 & 11.28 \\
\hline C. muconoides & 2.87 & 13.64 & 7.90 & 0.29 & 2.72 & 5.48 \\
\hline Physalis angulata & 11.73 & 5.74 & 3.15 & 4.63 & - & 5.05 \\
\hline S. cavennensis & 6.70 & 5.39 & 1.52 & 2.76 & 6.88 & 4.65 \\
\hline Digitaria $s p$ & - & 1.44 & - & 10.77 & 10.46 & 4.53 \\
\hline Paspalum $s p$ & - & 1.44 & - & 6.73 & 1.78 & 1.99 \\
\hline Solanum rugosum & 5.22 & 1.57 & - & 1.61 & - & 1.68 \\
\hline Sida rhombifolia & 1.70 & 2.42 & 0.63 & 0.56 & 2.27 & 1.52 \\
\hline Borreria latifolia & 3.63 & 1.67 & - & 0.23 & 2.02 & 1.51 \\
\hline Commelina benghalensis & 3.09 & 1.79 & - & 0.46 & - & 1.07 \\
\hline Solanum juripeba & - & 0.98 & - & 1.46 & 2.20 & 0.93 \\
\hline Sorghum halepense & - & - & - & 4.33 & - & 0.87 \\
\hline Eragrostis $s p$ & - & - & - & - & 4.15 & 0.83 \\
\hline Euphorbia prostrata & - & 0.48 & - & 2.83 & 0.54 & 0.77 \\
\hline Alternanthera ficoidea & - & 0.97 & 0.80 & 0.59 & 1.00 & 0.67 \\
\hline Rolandra fruticosa & - & 1.63 & - & 0.57 & 0.60 & 0.56 \\
\hline Cvperus distans & - & 2.28 & - & 0.52 & - & 0.56 \\
\hline H. aturensis & - & - & - & 0.51 & 2.21 & 0.54 \\
\hline Paspalum multicaule & - & 0.73 & 1.25 & 0.52 & - & 0.50 \\
\hline Brachiaria plantaginea & - & 0.41 & - & 1.43 & 0.31 & 0.43 \\
\hline Physalis pubescentes & - & 0.75 & 0.50 & 0.81 & - & 0.41 \\
\hline Fimbristylis $s p$ & - & - & - & - & 1.92 & 0.38 \\
\hline Euphorbia hyssopifolia & - & - & - & 0.67 & 1.07 & 0.35 \\
\hline Paspalum virgatum & - & 0.71 & - & 0.31 & 0.67 & 0.34 \\
\hline Borreria alata & - & 0.64 & - & 0.49 & 0.28 & 0.28 \\
\hline Euphorbia pilulifera & - & 1.13 & - & 0.22 & - & 0.27 \\
\hline Mimosa pudica & - & - & 0.68 & - & 0.57 & 0.25 \\
\hline Lantana camara & - & 0.72 & - & - & 0.29 & 0.20 \\
\hline Capim (sp 1) & - & - & - & - & 0.98 & 0.20 \\
\hline Cyperus diffusus & - & - & - & 0.92 & - & 0.18 \\
\hline Digitaria sanguinallis & - & - & 0.80 & - & - & 0.16 \\
\hline Eleusine indica & 0.64 & - & - & - & - & 0.13 \\
\hline Dichromena ciliata & - & 0.36 & - & - & 0.27 & 0.13 \\
\hline Phyllanthus niruri & - & - & - & - & 0.58 & 0.12 \\
\hline Cyperus sp & - & - & - & - & 0.58 & 0.12 \\
\hline Ageratum convzoides & - & - & 0.50 & - & - & 0.10 \\
\hline Crotum lobatum & - & - & - & 0.22 & 0.27 & 0.10 \\
\hline Commelina sp & - & - & - & - & 0.30 & 0.06 \\
\hline Asteraceae (sp 4) & $=$ & - & - & - & 0.29 & 0.06 \\
\hline O. angustifolius & - & - & - & - & 0.28 & 0.06 \\
\hline Vismia sp & - & - & - & - & 0.27 & 0.05 \\
\hline
\end{tabular}




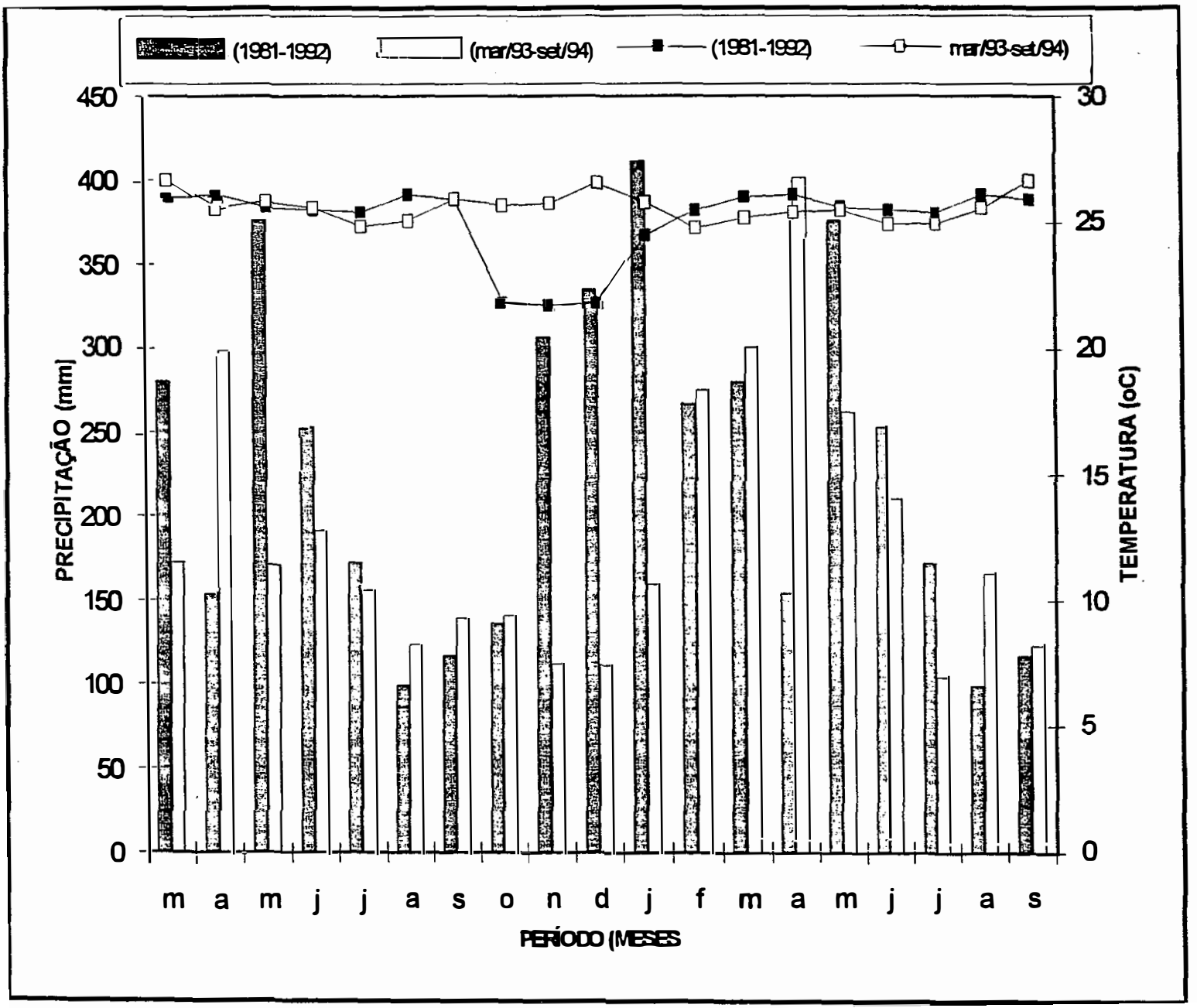

Figura 1 - Dados mensais de precipitação pluviométrica (mm) e médias mensais de temperatura $\left({ }^{\circ} \mathrm{C}\right)$ de mar/93 a set/94 e normais de 1981 a 1992 , registrados pela estação metereológica instalada no local do ensaio (EEDA, km 54 da BR 174). 